ANALYSIS OF WATER-QUALITY DATA AND SAMPLING PROGRAMS

AT SELECTED SITES IN NORTH-CENTRAL COLORADO

By David K. Mueller

U.S. GEOLOGICAL SURVEY

Water-Resources Investigations Report 90-4005

Prepared in cooperation with the

NORTHERN COLORADO WATER CONSERVANCY DISTRICT and the

U.S. BUREAU OF RECLAMATION

Denver, Colorado

1990 
DEPARTMENT OF THE INTERIOR

MANUEL LUJAN, JR., Secretary

U.S. GEOLOGICAL SURVEY

Dallas L. Peck, Director

For additional information write to:

District Chief

U.S. Geological Survey

Box 25046, Mail Stop 415

Federal Center

Denver, CO 80225-0046
Copies of this report can be purchased from:

U.S. Geological Survey

Books and Open-File Reports Section Box 25425

Federal Center

Denver, CO 80225-0425 
Abstract-10 Page

Introduction-1.

Purpose and scope-1 3

Approach--

Description of the study area-c 5

Operation of the Colorado-Big Thompson and Windy Gap Projects--.--- 8

Location of water-quality sampling sites-a 9

Data compilation-_. 10

Analysis of water-quality data-

Summary statistics-12

Trend analysis- 17

Analysis of sampling programs-

Comparison of selected sites-

Sampling frequency at streamflow sites-a

Sampling location at reservoir sites-

Laboratory analyses-- 50

Summary and conclusions-- 55

Water-quality data-n 55

Sampling programs-1.- 56

References cited-_. 57

Hydrologic data- 58

FIGURES

1. Location of the study area and sampling sites------- 5

2. Location of the Northern Colorado Water

Conservancy District-- 6

3. Location of the Colorado-Big Thompson Project

features-.-.-.-.- 7

4. Schematic of the primary water diversion and delivery system for the Colorado-Big Thompson and Windy Gap

Projects-_-_..- 8

5. Example of regression plot comparing data from two sites-- 23

6. Example diagram of a box plot-_. 28

7-11. Box plots of selected data distributions for various sampling frequencies at:

7. Site 2, Granby Pump Canal near Grand Lake-.....-. 30

8. Site 3, Adams Tunnel at east portal-_...........- 33

9. Site 7, Boulder Creek at mouth-_.. 37

10. Site 9, South Platte River near Weldona--_-_-_--- 40

11. Site 10, Colorado River near Radium-..- 44

12. Box plots of selected data distributions for surface and bottom samples from the north (N), center (C), and south (S) sampling stations at site 5 ,

Horsetooth Reservoir near Fort Collins-........ 48

13. Box plots of selected data distributions for surface and bottom samples from the north (N), center (C), and south (S) sampling stations at site 6 , Carter Lake near Berthoud-...- 
Table 1. Water-quality sampling sites selected for analysis in this study-...

Page

ater-quality properties and constituents, number of values, and percentage of values less than detection limits for analyses of samples collected at the study

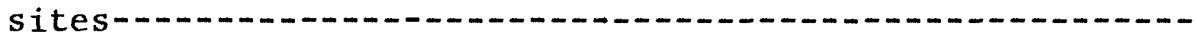

3. Summary of significant positive and negative trends at all study sites-...

4. Results of regression analysis of data from site 3, Adams Tunnel at east portal with data from site 4, Olympus Tunnel at Lake Estes...

5. Results of regression analysis of data from site 8 , South Platte River at Masters with data from site 9, South Platte River near Weldona-...

6. Significance of differences in water-quality properties and constituents among selected bimonthly and quarterly sampling schedules at site 2, Granby Pump Canal near

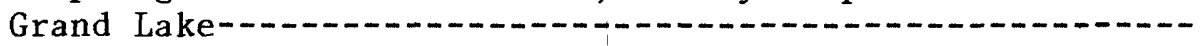

7. Significance of trends in water-quality properties and constituents for various sampling frequencies at site

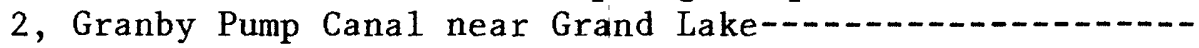

8. Significance of differences in water-quality properties and constituents among selected bimonthly and quarterly sampling schedules at site 3 , Adams Tunnel at east portal-n.

9. Significance of trends in water-quality properties and constituents for various sampling frequencies at site 3 , Adams Tunnel at east portal-

10. Significance of differences in water-quality properties and constituents among selected bimonthly and quarterly sampling schedules at site 7, Boulder Creek at mouth-----

11. Significance of trends in water-quality properties and constituents for various sampling frequencies at site 7 , Boulder Creek at mouth

12. Significance of differences in water-quality properties and constituents among selected bimonthly and quarterly sampling schedules at site 9, South Platte River near Weldona--...-

13. Significance of trends in water-quality properties and constituents for various sampling frequencies at site 9, South P1atte River near Weldona-ignificance of differences in water-quality properties and constituents among selected bimonthly and quarterly sampling schedules at site 10, Colorado River near Radium-1.-1

15. Significance of trends in water-quality properties and constituents for various sampling frequencies at site 10, Colorado River near Radium-

16. Significance of differences in water-quality properties and constituents among sampling locations and between sampling depths at site 5 , Horsetooth Reservoir near Fort Collins-1 
Table 17. Significance of differences in water-quality properties and constituents among sampling locations and between sampling depths at site 6, Carter Lake near Berthoud---- 51

18. Proposed schedule for onsite measurements and laboratory analyses for samples from all study sites- 53

19-28. Summary statistics for:

19. Site 1, Lake Granby near Granby-_.- 59

20. Site 2, Granby Pump Canal near Grand Lake-_-_._-.- 60

21. Site 3, Adams Tunnel at east portal-_- 61

22. Site 4, Olympus Tunne1 at Lake Estes-_- 62

23. Site 5, Horsetooth Reservoir near Fort Collins--.--- 63

24. Site 6, Carter Lake near Berthoud-_-_.- 65

25. Site 7, Boulder Creek at mouth-_... 66

26. Site 8, South Platte River at Masters-_-_._- 67

27. Site 9, South Platte River near Weldona--------- 68

28. Site 10, Colorado River near Radium-_... 69

29-38. Trend analysis results for:

29. Site 1, Lake Granby near Granby-_ 70

30. Site 2, Granby Pump Canal near Grand Lake--_-_-_--- 71

31. Site 3, Adams Tunnel at east portal-_- 72

32. Site 4, 01ympus Tunnel at Lake Estes-_-_ 73

33. Site 5, Horsetooth Reservoir near Fort Collins------- 74

34. Site 6, Carter Lake near Berthoud-_- 75

35. Site 7, Boulder Creek at mouth-_- 76

36. Site 8, South Platte River at Masters-_-_- 77

37. Site 9, South Platte River near Weldona--_-_-_-_- 78

38. Site 10, Colorado River near Radium-_- 79

\section{CONVERSION FACTORS}

\section{Multiply}

acre

acre-foot (acre-ft)

$\begin{array}{ll}\text { acre-foot (acre-ft) } & 1,233 \\ \text { acre-foot per year (acre-ft/yr) } & 1,233\end{array}$

cubic foot per second $\left(\mathrm{ft}^{3} / \mathrm{s}\right)$

inch (in.)

foot ( $f t$ )

mile (mi)
By

0.4047

0.028317

2.54

0.3048

1.604
To obtain

hectare

cubic meter

cubic meter per year

cubic meter per second centimeter

meter

kilometer

Degree Celsius $\left({ }^{\circ} \mathrm{C}\right)$ may be converted to degree Fahrenheit ( ${ }^{\circ} \mathrm{F}$ ) by using the following equation:

$$
{ }^{\circ} \mathrm{F}=9 / 5\left({ }^{\circ} \mathrm{C}\right)+32
$$

Other terms and abbreviations used in this report are:

colonies per 100 milliliters (colonies/100mL)

microgram per liter $(\mu \mathrm{g} / \mathrm{L})$

microsiemens per centimeter at 25 degrees Celsius $(\mu \mathrm{S} / \mathrm{cm})$

milligram per liter $(\mathrm{mg} / \mathrm{L})$. 


\section{ANALYSIS OF WATER-QUALITY DATA AND SAMPLING PROGRAMS AT SELECTED SITES IN NORTH-CENTRAL COLORADO}

By David K. Mueller

\section{ABSTRACT}

Data from U.S. Geological Survey water-quality sampling stations at 10 sites in north-central Colorado were analyzed by using a variety of statistical procedures in order to determine characteristics of the data and to evaluate the sampling programs. All these sites were associated with the Colorado-Big Thompson Project, which is operated and maintained by the Northern Colorado Water Conservancy District and the U.S. Bureau of Reclamation.

Mean values of specific conductance were 50-60 microsiemens per centimeter at headwater sites and increased to about 1,600 microsiemens per centimeter downstream. Mean pH increased from about 7.1-7.5 in the headwaters to about 8.1 at downstream sites. Nutrient concentrations were low at most sites; mean concentrations of nitrogen species generally were less than 1 milligram per liter, and mean phosphorus concentrations were less than 0.2 milligram per liter. However, mean phosphorus concentrations at downstream sites in the South Platte River basin were as high as 0.9 milligram per liter. Based on total phosphorus concentrations, the risk of eutrophication related water-quality problems is small to moderate at reservoir sites. Most trace constituent concentrations were low, but copper and lead concentrations occasionally exceeded State water-quality standards at several sites. Median bacterial concentrations generally were less than 4 colonies per 100 milliliters at sites that were not downstream from municipal wastewatertreatment plants.

Trend analyses indicated that specific conductance, dissolved-solids concentrations, and the concentrations of major dissolved consitiuents have decreased at many sites in the South Platte River basin during the period of record (from about 1970 through 1987). Significant decreases in dissolvedsolids concentration ranged from about 0.3-27 milligrams per liter per year. However, at one streamflow site in the Colorado River basin, dissolved-solids concentrations increased 4.4 milligrams per liter per year during 1981-87. other general trends indicated that phosphorus concentrations have decreased about 87-94 percent at reservoir sites and that bacterial concentrations have decreased about 80-96 percent downstream from treatment plants. 
Water-quality data from two pairs of sites were compared by using linearregression analysis to test for similarities between the sites. Neither comparison indicated substantial differences, which means most data at one site in each pair are redundant. Analysis of sampling frequency at streamflow sites was based on nonparametric testing for significant differences in characteristics of the distributions of data subsets, visual inspection of plots of these distributions, and comparison of trend analysis results from the entire data set and selected subsets. Data subsets were selected to represent decreased sampling frequencies at bimonthly or quarterly intervals. No substantial loss of information occured by decreasing sampling frequency to bimonthly at four sites and to quarterly at one site. The same procedures were applied to test for differences among sampling locations and between sampling depths at two reservoir sites. A suggested schedule of onsite measurements and laboratory analyses was developed based on criteria of providing consistency and determining compliance with water-quality standards.

\section{INTRODUCTION}

Water-quality sampling stations are established for a variety of purposes. Over time, as needs for water-quality data change, stations may be discontinued or added to provide information to meet those needs. A small network of surface-water-quality stations in north-central Colorado has been maintained during the past 18 years (1969-87) as part of the commitment the U.S. Geological Survey (hereinafter referred to as the Survey) has to the Pick-Sloan Missouri Basin Program. The U.S. Bureau of Reclamation (hereinafter referred to as the Bureau) cooperated with the Survey in water-quality data collection at these stations. The Bureau was interested in data from this network for use in project planning and for evaluation of the operation of their Colorado-Big Thompson (CBT) Project. By 1987, the Bureau had completed or suspended planning studies in the CBT project area and had transferred operation and maintenance of part of the CBT Project to the Northern Colorado Water Conservancy District (hereinafter referred to as the District).

In 1987, the District already was cooperating with the Survey in the operation of several water-quality stations associated with CBT Project facilities in the Colorado River basin. The District's primary purpose for data collection was to provide information about baseline water quality in the area affected by operation of the CBT Project. Specific concerns included monitoring compliance with existing standards and potential contamination from constituents associated with agricultural runoff. The District was interested in maintaining data collection at some of the Missouri Basin Program stations for the purpose of evaluating CBT Project operations in the South Platte River Basin.

All three agencies agreed that an analysis of the available data and the current (1987) sampling program was needed to provide direction for a continued program. Before stations were discontinued or changes were made in the program, it was decided to evaluate the data being collected and the frequency of sampling. In addition, a summary of the existing data was needed to document water-quality conditions at the CBT Project sites. 


\section{Purpose and Scope}

This report provides an analysis of the water-quality data at selected sites and provides an evaluation of the suitability of the current (1987) sampling programs at each site for meeting future needs of defining water quality within the area affected by CBT Project operations. Specific objectives of the report are to:

1. Provide summary statistics of water-quality data at each site for the period of record.

2. Identify significant trends for water-quality constituents or properties at each site.

3. Determine whether certain stations could be discontinued without substantial loss of information.

4. Determine whether the frequency of sampling for any individual constituent or groups of constituents at any of the sites could be decreased without substantial loss of information.

5. Evaluate which water-quality constituents and properties need to be measured in order to meet the water-quality-data needs at each site.

Fourteen streamflow and reservoir stations were selected for this analysis. Data were available from three stations each at two reservoirs. As a result, data from 10 sites were analyzed (table 1, fig. 1). These sites represent a network of water-quality sampling stations that can be used to evaluate the effects of CBT Project water transfers on both sides of the Continental Divide. Four of these sites are on natural streams, three are on CBT Project carriage facilities, and three are on CBT Project reservoirs.

\section{Approach}

Objectives 1, 2, and 3 listed in the "Purpose and Scope" section were accomplished by applying parametric and nonparametric statistical procedures to the distribution and time series of the historical data. Trends (objective 2) were computed for concentration and flow-adjusted concentration. The flow-adjustment procedure, described later in this report, was intended to eliminate the effect of correlation between streamflow and concentrations of chemical constituents during the period of record. Trends were interpreted in relation to anthropogenic activities such as water diversions, irrigation practices, and wastewater treatment upstream from the station; in relation to trends that occurred for the same constituents at other stations; and in relation to trends that occurred for other constituents at the same station. Objective 3 was applied only to stations that were in close proximity and had the same primary source of water.

Objectives 4 and 5 resulted in a proposed sampling program for each site, which included a list of constituents for laboratory analysis and a sampling frequency for each constituent. The necessary sampling frequency (objective 4) was evaluated by determining the ability of selected subsets of the historical data to maintain the distributional parameters, such as the median and variance, of the entire data set. The list of constituents was developed based on the following criteria: 
1. To provide consistency with past data collection and with other ongoing water-quality data-collection programs,

2. To provide consistency among sites, and

3. To allow determination of compliance with water-quality standards.

If known, additional site-specific uses of water-quality data from each site were considered; however, potential uses of the data by anyone other than the project cooperators may not have been identified. The actual selection of a sampling program for an individual site could be based on factors not considered in this report.

Other possible analyses that could have been made using the historical data base but were not considered in this study include determination of the effects of existing or proposed water-resources development and determination of constituent loading to proposed reservoirs. The first of these analyses probably would require a computer model of the river-aquifer system to adequately define cause-and-effect relations. Also, this study did not assess the possible need for additional stations to provide for adequate areal characterization of water quality throughout the CBT Project area. Although such an assessment would be needed for designing a water-qualitymonitoring network, the scope of this study was limited to evaluating individual monitoring sites in the existing network.

Table 1.--Water-quality sampling sites selected for analysis in this study

[Station numbers and names are those assigned by the U.S. Geological Survey]

\begin{tabular}{|c|c|c|c|c|}
\hline $\begin{array}{c}\text { Site } \\
\text { number } \\
(\mathrm{fig} \cdot 1)\end{array}$ & $\begin{array}{l}\text { Station } \\
\text { number }\end{array}$ & Station name & $\begin{array}{l}\text { Number } \\
\text { of } \\
\text { samples }\end{array}$ & $\begin{array}{l}\text { Period } \\
\text { of } \\
\text { record }\end{array}$ \\
\hline 1 & 09018500 & Lake Granby near Granby & 29 & $1973-87$ \\
\hline 2 & 09018300 & Granby Pump Canal near Grand Lake & 102 & $1972-87$ \\
\hline 3 & 09013000 & $\begin{array}{l}\text { Alva B. Adams Tunnel at east portal, } \\
\text { near Estes Park }\end{array}$ & 181 & $1970-87$ \\
\hline 4 & 06734900 & Olympus Tunnel at Lake Estes & 182 & $1971-87$ \\
\hline 5 & 06737500 & $\begin{array}{l}\text { Horsetooth Reservoir near Fort Collins, } \\
\text { near north end }\end{array}$ & 206 & $1969-87$ \\
\hline 5 & 403317105090000 & $\begin{array}{l}\text { Horsetooth Reservoir near Fort Collins, } \\
\text { near center }\end{array}$ & 23 & $1983-87$ \\
\hline 5 & 403147105083800 & $\begin{array}{l}\text { Horsetooth Reservoir near Fort Collins, } \\
\text { near south end }\end{array}$ & 23 & $1983-87$ \\
\hline 6 & 402053105125800 & $\begin{array}{l}\text { Carter Lake near Berthoud, } \\
\text { near north end }\end{array}$ & 19 & $1983-87$ \\
\hline 6 & 402009105130700 & $\begin{array}{l}\text { Carter Lake near Berthoud, } \\
\text { near center }\end{array}$ & 19 & $1983-87$ \\
\hline 6 & 06742500 & $\begin{array}{l}\text { Carter Lake near Berthoud, } \\
\text { near south end }\end{array}$ & 193 & $1970-87$ \\
\hline 7 & 06730500 & Boulder Creek at mouth near Longmont & 95 & $1979-87$ \\
\hline 8 & 06756995 & South Platte River at Masters & 97 & $1977-87$ \\
\hline 9 & 06758500 & South Platte River near Weldona & 203 & $1971-87$ \\
\hline 10 & 09058030 & Colorado River near Radium & 49 & $1981-87$ \\
\hline
\end{tabular}




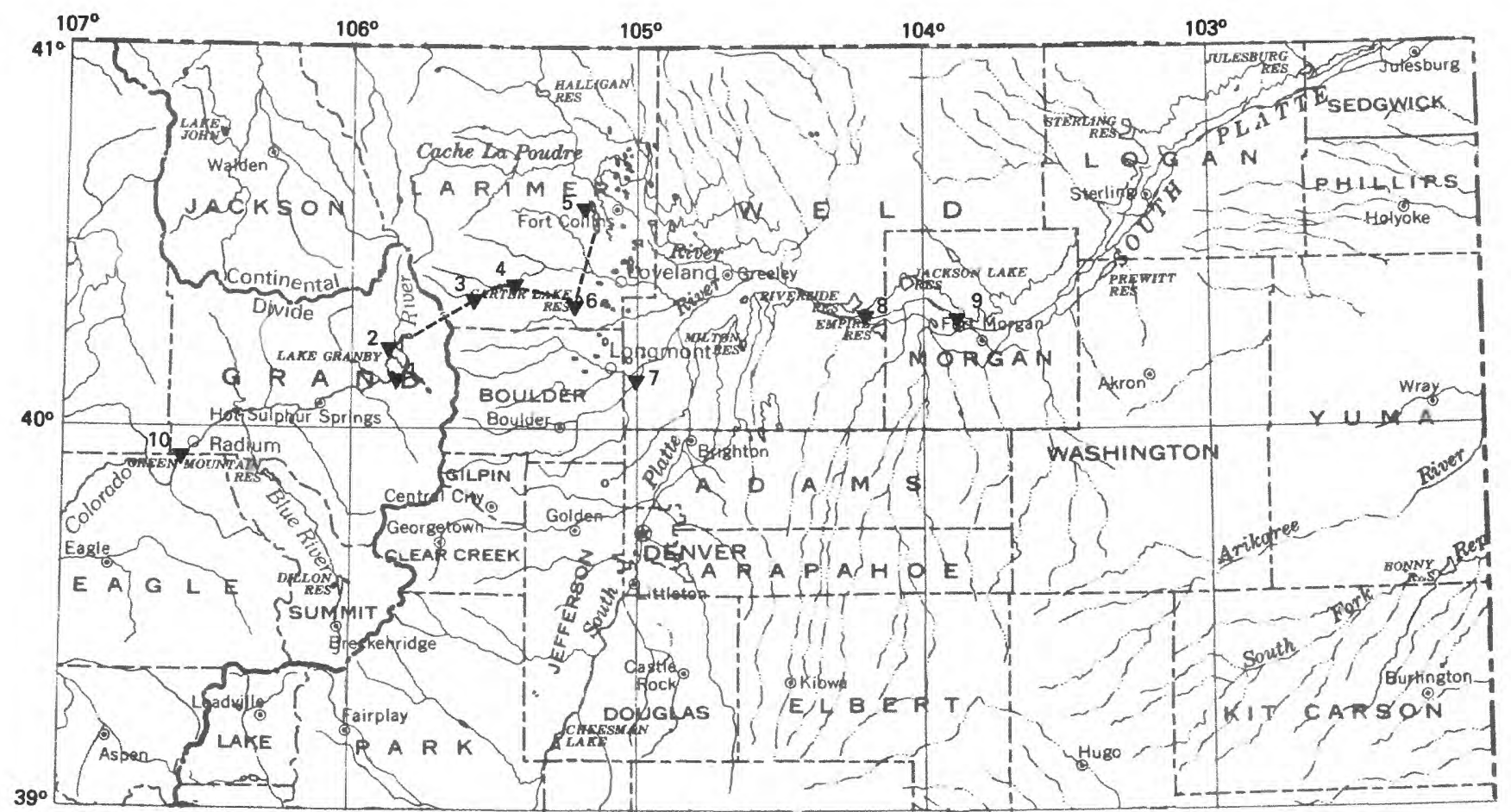

Base from U.S. Geological Survey,

$7: 2,500,000$

\section{EXPLANATION}

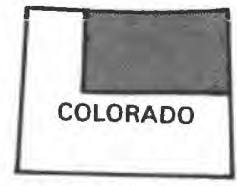

LOCATION MAP

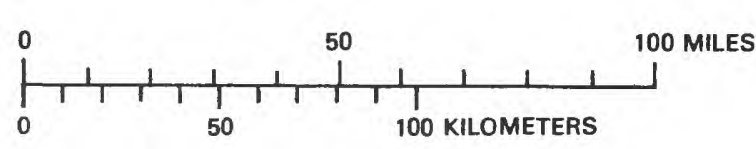

100 KILOMETERS

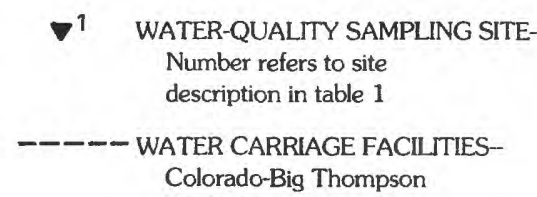

Colorado-Big Thompson Prodject

Figure 1.--Location of the study area and sampling sites.

\section{DESCRIPTION OF THE STUDY AREA}

The study area includes the headwater basin of the Colorado River on the western side of the Continental Divide and the middle part of the South Platte River basin, including headwater tributaries, on the eastern side of the Continental Divide (fig. 1). The facilities of the CBT Project and the service area of the District are included in this area. The CBT Project facilities divert water from the Colorado River basin through the Alva B. Adams Tunnel (hereinafter referred to as the Adams tunnel) to the South Platte River basin, where it is stored and delivered for irrigation and municipal use in the District's service area.

The District was established in 1937 to contract with the Federal Government to build the CBT Project and to operate the facilities of the completed system. The service area of the District encompasses 1,481,600 acres and includes the cities of Boulder, Fort Collins, Fort Morgan, Greeley, Longmont, Loveland, Julesburg, and Sterling (fig. 2). Population of the 


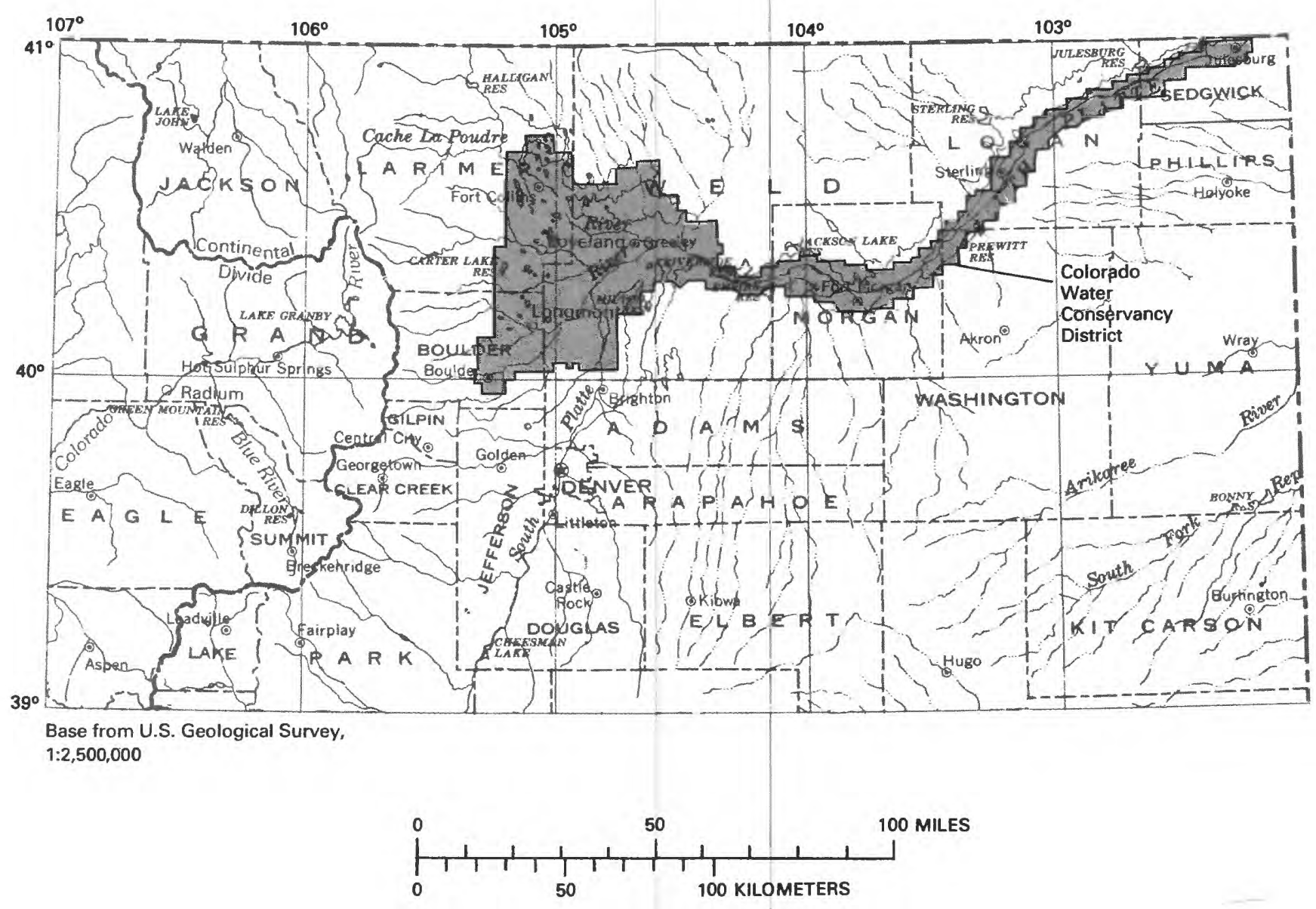

Figure 2.--Location of the Northern Colorado Water Conservancy District.

District was 425,000 in 1987 (Northern Colorado Water Conservancy District, 1987). The CBT Project provides supplemental irrigation water to 2,645 farms in the District (U.S. Bureau of Reclamation, 1985).

The CBT Project was authorized by Congress in June 1937, and construction began in December of the following year. The first project water was delivered through the Adams Tunnel (fig. 3) to the South Platte River basin in June 1947. The primary storage reservoirs, Shadow Mountain Lake and Lake Granby on the western side of the Continental Divide and Horsetooth Reservoir and Carter Lake on the eastern side, were completed between 1945 and 1954 . The final feature of the originally authorized project was completed in 1956, and the Bureau began transferring the operation and maintenance of project facilities to the District. By 1988, the District had assumed operation and maintenance responsibility for a large part of the project. The facilities at that time included 14 storage reservoirs and $120 \mathrm{mi}$ of tunnels and canals. In 1984 , the project supplied more than 210,000 acre-ft of water for irrigation of 632,000 acres and approximately 38,000 acre-ft for municipal and industrial use (U.S. Bureau of Reclamation, 1985). 


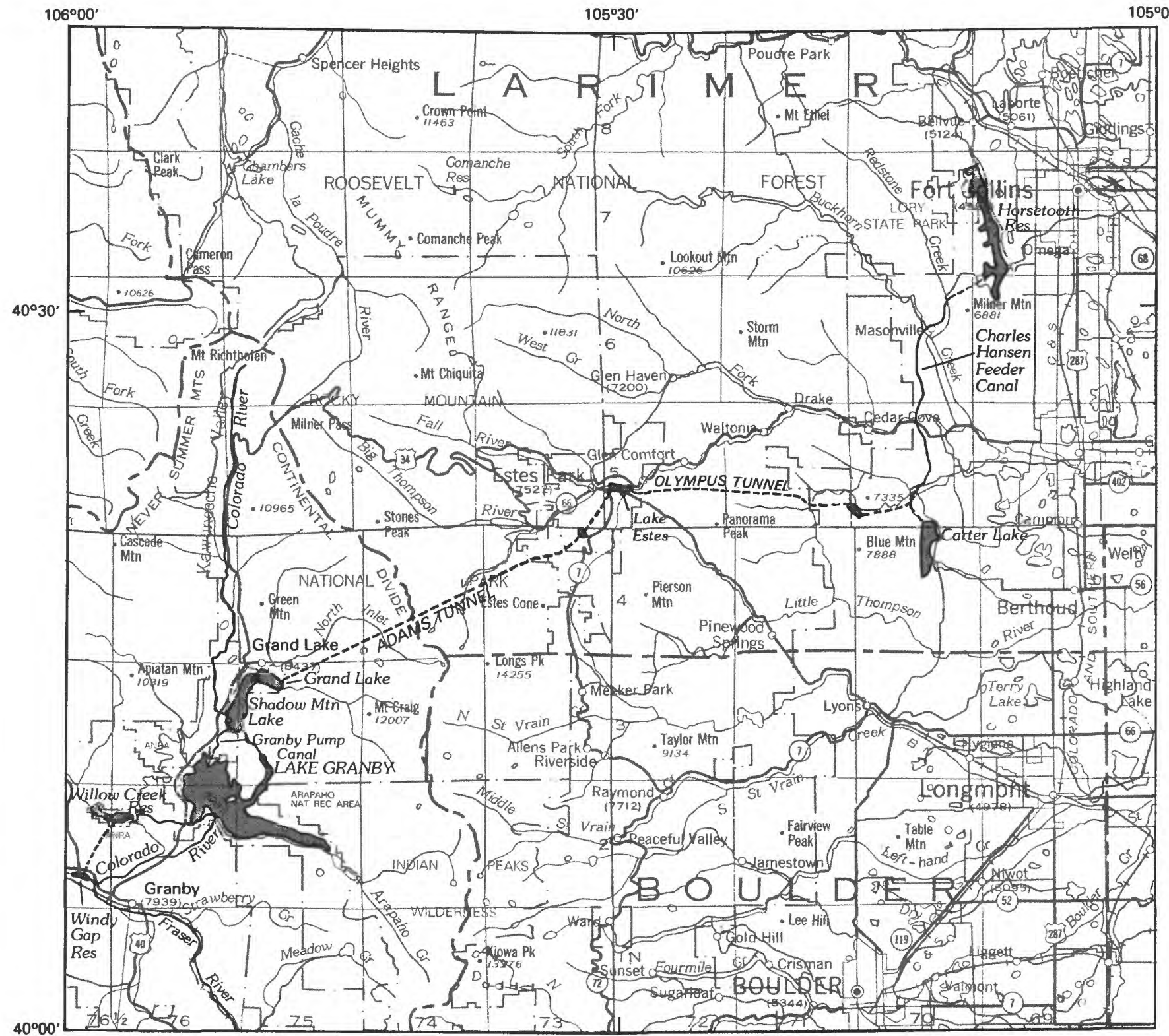

Base from U.S. Geological Survey,

State base map, 1980
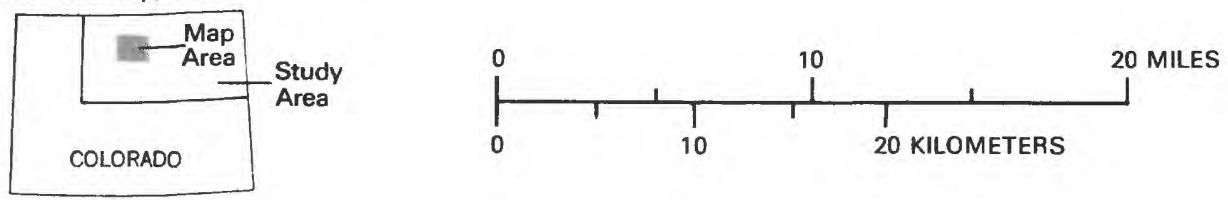

Figure 3.--Location of Colorado-Big Thompson Project features. 
The Municipal Subdistrict, Northern Colorado Water Conservancy District, was established in 1970 to promote development of additional municipal water supplies for the District area. In 1985, the Subdistrict completed work on the Windy Gap Reservoir at the confluence of the Colorado and Fraser Rivers (fig. 3). Water from Windy Gap is conveyed to the District's service area by using the existing facilities of the CBT Project. During 1986, the total diversion from the CBT and Windy Gap Projects through the Adams Tunnel was 284,200 acre-ft (U.S. Geological Survey, 1988b).

\section{Operation of the Colorado-Big Thompson and Windy Gap Projects}

The principal features of the CBT and Windy Gap Projects are shown in figure 3 and the movement of water is shown schematically in figure 4. Colorado River basin water is stored in four reservoirs for diversion to the South Platte River basin. Water from Windy Gap and Willow Creek Reservoirs is pumped up to Lake Granby. From there, it flows through the Granby Pump Canal into Shadow Mountain Lake, a reservoir that connects to Grand Lake. Diversions from Grand Lake flow by gravity through the Adams Tunnel to the South Platte River basin.

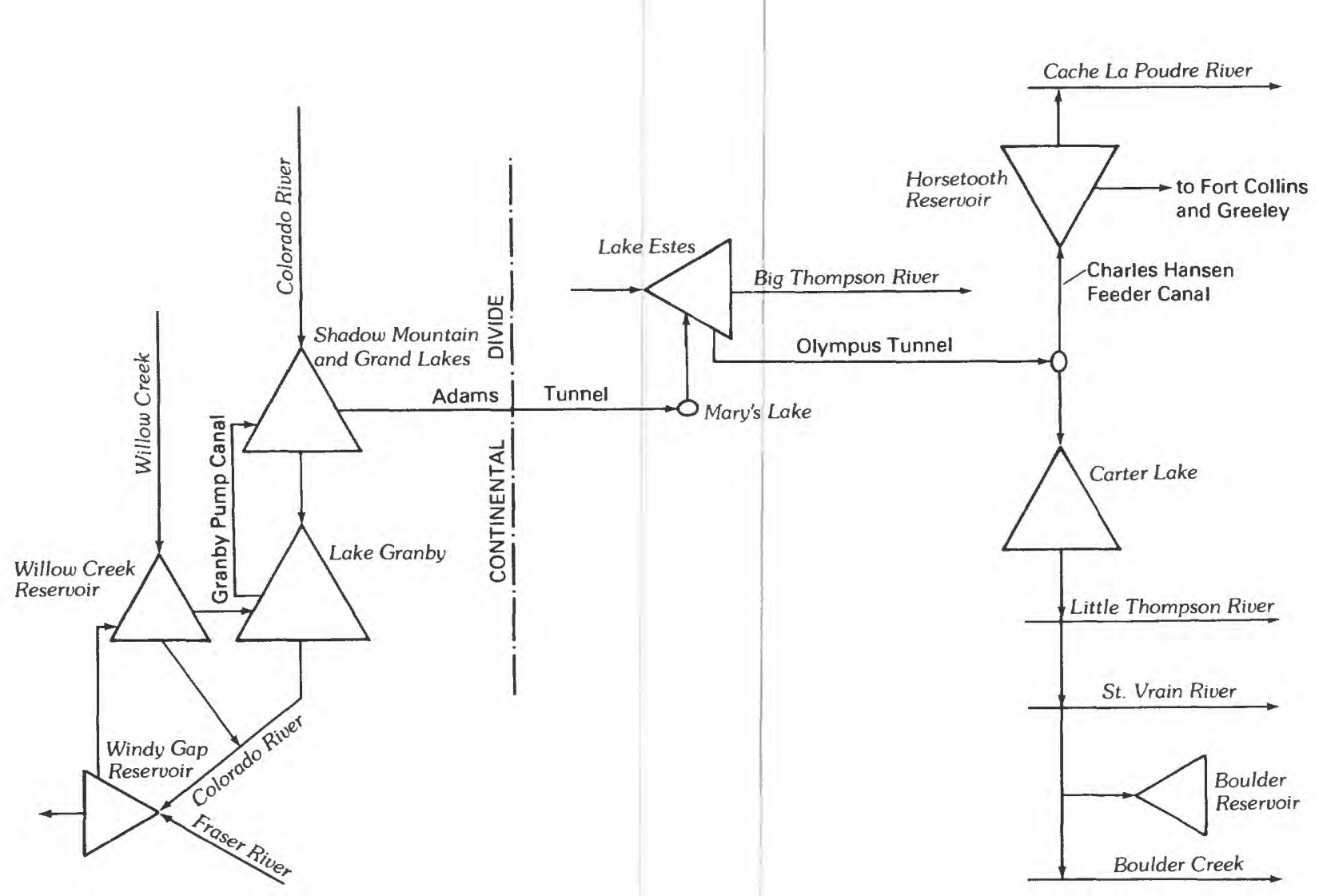

Figure 4.--Schematic of the primary water diversion and delivery system for the Colorado-Big Thompson and Windy Gap Projects. 
After emerging from the Adams Tunnel, water flows into Lake Estes, a reservoir on the Big Thompson River. From Lake Estes, water is conveyed by a series of tunnels and canals, including the 0lympus Tunnel, to Horsetooth Reservoir and Carter Lake. Water in Horsetooth Reservoir is delivered to the Cache la Poudre River and to the cities of Fort Collins and Greeley. Water from Carter Lake is delivered to the Little Thompson River, St. Vrain Creek, Boulder Creek, and the municipal supply reservoir of the city of Boulder.

An additional feature of the CBT Project is Green Mountain Reservoir on the Blue River, a tributary to the Colorado River (fig. 1). This reservoir was constructed to produce hydroelectric power, to develop marketable water supplies, and to provide water to users in the Colorado River basin whose supply would otherwise be diminished by diversions through the Adams Tunnel.

\section{Location of Water-Quality Sampling Sites}

Although they were established for several different purposes, the ten water-quality sampling sites selected for this study can be considered a network to evaluate the effects of CBT and Windy Gap Project operations. Site 1 is in Lake Granby (table 1, fig. 1), which receives inflow from the Colorado River, Willow Creek Reservoir and, beginning in 1985, Windy Gap Reservoir. Lake Granby is the largest reservoir in the CBT Project system, with a total storage capacity of 539,800 acre-ft (U.S. Bureau of Reclamation, 1981). Mean depth of the reservoir at full active storage is about $74 \mathrm{ft}$. Storage began in 1949, and the reservoir reached usable capacity in 1950 . Average inflow from the Colorado River is estimated to be approximately 230,000 acre-ft/yr (U.S. Bureau of Reclamation, 1981). Site 2 is on the Granby Pump Canal, which conveys water from Lake Granby to Shadow Mountain Lake and Grand Lake. The canal has a capacity of $1,100 \mathrm{ft}^{3} / \mathrm{s}$. Periods of no flow in the canal can occur throughout the year.

Site 3 is at the east portal of the Adams Tunnel, where water from Grand Lake is delivered to the South Platte River basin. Samples from this site also are considered to be representative of water quality in the headwaters of the Colorado River.

Site 4 is at the entrance to the 0lympus Tunnel, which receives water from Lake Estes. In 1985, approximately one-half of the outflow from Lake Estes was diverted through the 0lympus Tunnel and one-half was released into the Big Thompson River. The tunnel has a capacity of $550 \mathrm{ft}^{3} / \mathrm{s}$ (U.S. Bureau of Reclamation, 1981).

Site 5 consists of three sampling stations in Horsetooth Reservoir, west of Fort Collins. This reservoir is formed by four dams that block openings along a hogback ridge. It has a total capacity of 151,800 acre-ft and a mean depth of about $81 \mathrm{ft}$ (U.S. Bureau of Reclamation, 1981). Essentially the only source of inflow is from the Charles Hansen Feeder Canal. Storage began in 1951.

Site 6 is similar to site 5 , consisting of three sampling stations on Carter Lake, west of Loveland. This reservoir also is formed by dams that block openings along a hogback, and its primary inflow is CBT Project water. 
It has a total capacity of 112,200 acre-ft and a mean depth of about $98 \mathrm{ft}$ (U.S. Bureau of Reclamation, 1981). Storage began in 1954.

Site 7 is on Boulder Creek, which receives a part of the outflow from Carter Lake. The mean daily streamflow at the site during 35 years of record through 1987 was about $67 \mathrm{ft}^{3} / \mathrm{s}$ (U.S. Geological Survey, 1988a).

Sites 8 and 9 are on the South Platte River downstream from much of the irrigated area served by the CBT Project. Site 8 was established in 1977 to provide data on nutrient inflow to the proposed Narrows Reservoir. Site 9 is only about 21 river miles downstream but has a longer period of record. Streamflow measurement began in 1952 and water-quality sampling began in 1971. Streamflow records at site 9 are collected and computed by the Colorado Division of Water Resources and were published by the U.S. Geological Survey through 1985. Mean daily streamflow was $1,190 \mathrm{ft}^{3} / \mathrm{s}$ at site 8 for $1978-85$ and $1,059 \mathrm{ft}^{3} / \mathrm{s}$ at site 9 for $1976-85$ (U.S. Geological Survey, 1986). Substantial flow is diverted between the sites for irrigation during April through October.

Site 10 is on the Colorado River, downstream from all CBT and Windy Gap Project features, including Green Mountain Reservoir on the Blue River. The site originally was established to provide planning data for the proposed Azure Reservoir, which was to be part of the Windy Gap Project. Mean daily streamflow at the site for 6 years through 1987 was $1,484 \mathrm{ft}^{3} / \mathrm{s}$ (U.S. Geological Survey, 1988b).

\section{DATA COMPILATION}

All data used in this study were retrieved from the Water Data Storage and Retrieval System (WATSTORE) data base of the U.S. Geological Survey stored on the PRIME ${ }^{1}$ computer system. The retrieval procedure selected all data available for each of the 14 stations included in the study. More than 22,000 data values from about 1,400 samples were retrieved.

Data for some water-quality properties and constituents are stored under more than one parameter code in WATSTORE. These data were combined after the initial retrieval to produce a preliminary list of properties and constituents for analysis. For example, alkalinity values are stored under two parameter codes and also can be computed from bicarbonate and carbonate concentrations. The hierarchy established to evaluate alkalinity was: (1) Use the laboratory, fixed end-point titration (parameter code 95410); (2) otherwise, use the unspecified method (parameter code 00410); (3) if both are missing, compute alkalinity from bicarbonate (parameter code 00440) and, if available, carbonate (parameter code 00445). Other parameter codes that were combined to evaluate certain single constituents included those for bacteria, nutrients,

${ }^{1}$ Use of brand, firm, or trade names in this report is for identification purposes only and does not constitute endorsement by the U.S. Geological Survey. 
and major cations. Combined codes for bacteria represented different analytical methods. For nutrients, combinations were used to obtain values in standard reporting units. Nitrogen and phosphorus species are reported as concentrations of only nitrogen and phosphorus components.

The preliminary set of property and constituent data then was analyzed to determine obvious errors. These analyses included stem-and-leaf diagrams, box plots, time-series plots, and correlation plots for selected constituents (Chambers and others, 1983). For all samples with major cation and anion data, the charge balance was computed and the theoretical specific conductance (Tanji and Biggar, 1972) was compared to onsite and laboratory measurements. Based on these analyses, 47 extreme outliers or questionable values wẻre deleted from the data set. In addition, thirteen data values were corrected based on published values in annual U.S. Geological Survey data reports, and 13 other data values were changed based on charge-balance corrections or obvious decimal point misplacement. The total of 73 obvious errors represented about 0.3 percent of the data set. The analyses also indicated that phytoplankton cell counts and algal-growth-potential data varied inconsistently, both seasonally and during the period of record; therefore, these data were not used in subsequent analyses.

A limited number of paired data values were available for total and dissolved concentrations of soluble nutrient species. The correlation coefficient for 30 concurrent analyses of total and dissolved nitrite plus nitrate at site 1 was 0.91 , and the mean concentrations were identical. The correlation coefficient for 13 concurrent analyses of total and dissolved ammonia at site 5 was 0.64 , and the difference in means was only $0.03 \mathrm{mg} / \mathrm{L}$. Therefore, total values were substituted for missing dissolved values, if possible, for nitrite plus nitrate and ammonia. The majority of the nitrite plus nitrate substitutions took place for sites $1,2,8$, and 10 . The majority of the ammonia substitutions took place for sites $1,4,5$, and 6 .

The sum of major dissolved constituents and hardness were computed for each sample that had sufficient data. Constituents required to compute the sum were calcium, magnesium, sodium, chloride, sulfate, and alkalinity. Others that were added, if available, were potassium, fluoride, silica, and nitrite plus nitrate. This definition of dissolved solids is less restrictive than the one used to compute sum-of-constituents data in WATSTORE and was used in this study to determine a value for dissolved solids if only minor constituents were missing from the analysis. Finally, values of zero, indicating a concentration that was less than the limit of detection, were changed to less than the most common detection limit in the data set for that constituent.

Water-quality properties and constituents used in this study are listed in table 2. The total number of data values is shown for each site, along with the percentage of values that were less than the detection limit. For the reservoir sites $(1,5$, and 6$)$, only data from surface and bottom samples are included. Samples from the Adams and olympus Tunnels (sites 3 and 4) were excluded if flow was less than $20 \mathrm{ft}^{3} / \mathrm{s}$, which indicates that no water was being diverted. The list contains 51 properties and constituents. For nine of these constituents (dissolved and total nitrite, dissolved and total recoverable cadmium, cyanide, mercury, silver, selenium, and sulfide), more than one-half the values at all sites were less than detection limits; therefore, 
these constituents were of limited value in subsequent analyses. Dissolved solids are listed twice, as the computed sum of constituents and as the analyzed residue on evaporation at $180{ }^{\circ} \mathrm{C}$. Data were available for sum of constituents and residue on evaporation at three sites (4, 5, and 10), but the periods of record were different.

Sampling frequency during the period of record used in this study was approximately monthly at most of the streamflow sites $(3,4,7,8$, and 9). The exceptions were site 2 (Granby Pump Canal), which was visited monthly but only sampled if water was flowing, and site 10 (Colorado River near Radium), where samples were collected monthly from March or April through November. Sampling at the reservoir sites has been more irregular.

Lake Granby (site 1) was sampled quarterly from August 1973 through June 1975. Samples were collected from near the surface at the single station on the reservoir. Beginning in June 1978, samples were collected annually in June or July from near the surface and near the bottom at the station.

Sample collection began in September 1969 at Horsetooth Reservoir (site 5) and in February 1970 at Carter Lake (site 6). Sampling frequency was approximately monthly at both reservoirs through September 1982. Initially, samples were collected from near the surface, near the bottom, and at an intermediate depth at one station on each reservoir (near the north end of Horsetooth Reservoir and near the south end of Carter Lake). Beginning in November 1978, samples were collected only from near the surface. After September 1982, sampling frequency was decreased to three times per year (May, July, and September). The number of sampling stations on each reservoir was increased to three: one near the north end, one near the center, and one near the south end. Samples were collected from near the surface and near the bottom at each station. The data set for sites 5 and 6 listed in table 2 includes samples from all three stations at each site, but only those collected near the surface or near the bottom.

\section{ANALYSIS OF WATER-QUALITY DATA}

The data compiled for each site were analyzed by using parametric and nonparametric (rank based) statistical procedures. The computational methods included packaged software (SAS Institute Inc., 1985a and 1985b) and software developed by the U.S. Geological Survey. These methods are described in addition to presentation of results in the following sections.

\section{Summary Statistics}

For each study site, seven distributional parameters were determined for all water-quality properties and constituents that had sufficient data. These parameters were the mean, standard deviation, minimum, lower quartile (25th percentile), median (50th percentile), upper quartile ( 75 th percentile), and maximum. The criteria for sufficient data were defined to be: (1) At least 10 values equal to or exceeding the detection limit; and (2) no more than 75 percent of the values less than the detection limit. The first criteria was 


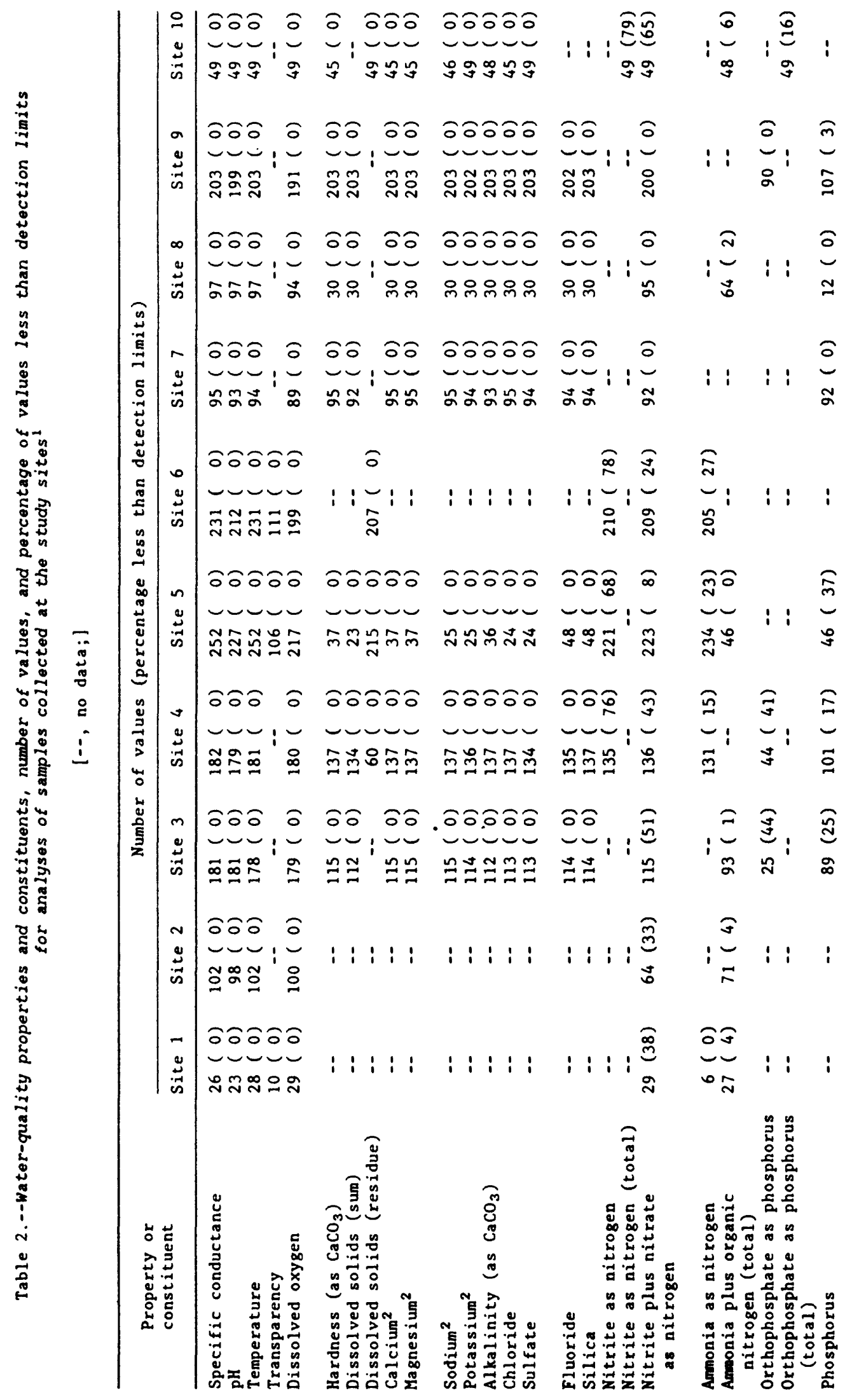




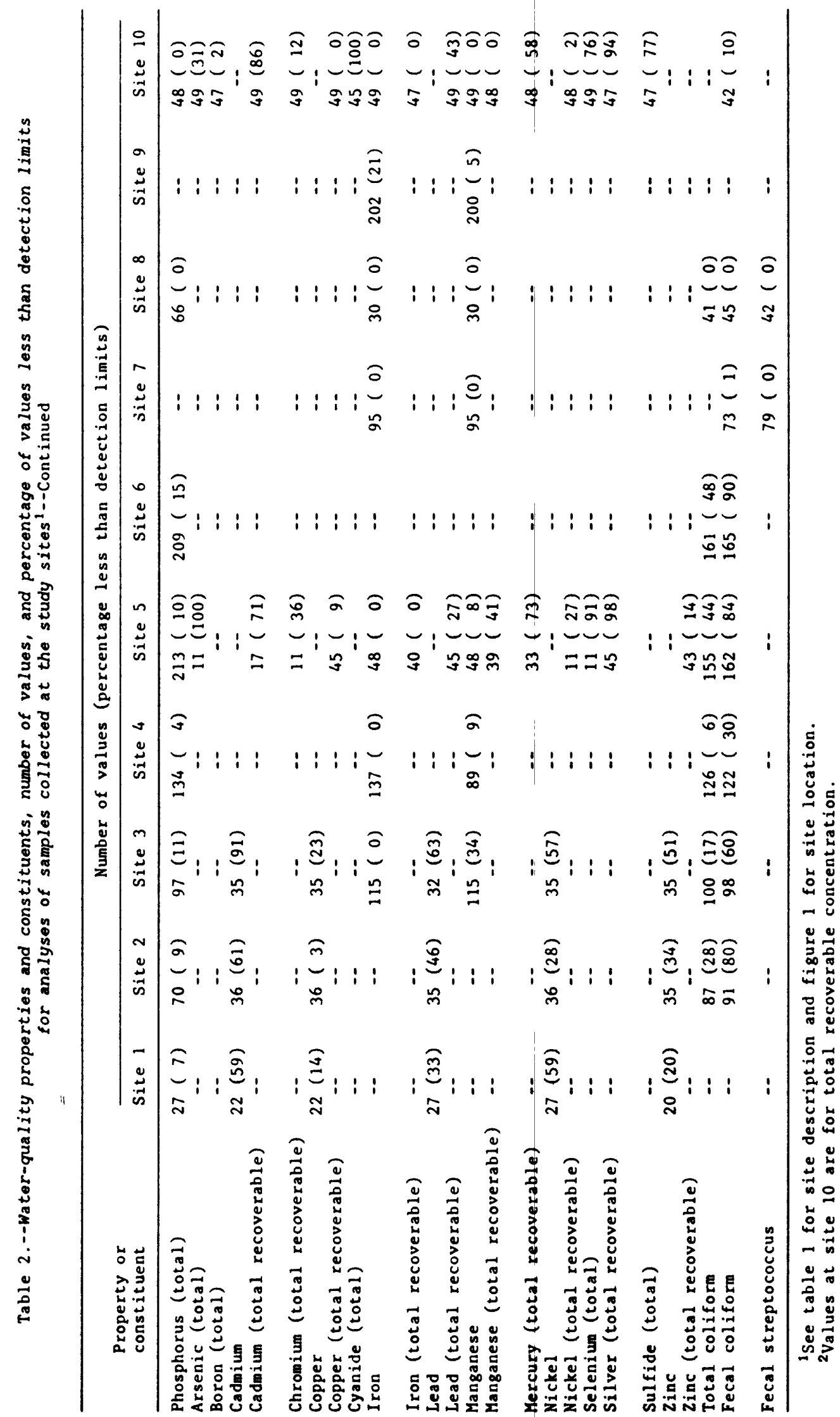


diminished to five values for site 1 (Lake Granby) because data were scarce for many properties and constituents. The second criteria was applied separately to surface and bottom samples from the reservoir sites $(1,5$, and 6$)$. If either criteria was not satisfied, only the minimum and maximum values were reported to indicate the range of measured values.

Because the data for many constituents included censored (less-than) values, the methods used to compute the summary statistics were selected based on their accuracy of estimating specific distributional parameters for data sets containing censored values. Gilliom and Helsel (1986) determined that log-probability regression was the best method to estimate the mean and standard deviation of such data sets and that a lognormal maximum-likelihood method was best for estimating the median and quartile values. The software used in the present study to compute the summary statistics incorporated these two methods, modified by Helsel and Cohn (1988) to accept data sets having more than one detection limit.

Summary statistics for the data compiled for the 10 sites in this study are listed in tables 19 through 28 (in the "Hydrologic Data" section at the back of this report). Also included in these tables are the applicable State water-quality standards that were in effect in 1987 (Colorado Department of Health, 1986; 1987). The standards are maximum allowable concentrations, except for the pH standard, which is an allowable range, and the dissolvedoxygen standard, which is a minimum allowable concentration. Where two values are listed for the dissolved-oxygen standard, the larger value applies during periods of spawning of cold-water fish. The standards for most trace metals were based on total recoverable concentration. These standards are listed for several sites where only dissolved trace-metal concentrations were available. At these sites, the total recoverable concentrations probably were higher than the tabulated dissolved concentrations. The standard for ammonia is for the un-ionized form, which at the $\mathrm{pH}$ and temperature of most of the samples from the study sites would be less than the reported ionic ammonia as nitrogen concentration. Similarly, the standard for sulfide is for undissociated hydrogen sulfide, which would be less than the reported concentration of total sulfide. No standards actually apply at sites 2, 3, and 4, the Granby Pump Cana1, Adams Tunnel, and Olympus Tunnel. The standards listed for these sites apply to their sources of water: Lake Granby for site 2, Grand Lake for site 3 , and Lake Estes for site 4.

Some general observations may be made about the summaries listed in tables 19 through 28 . Mean values of specific conductance, which is an indicator of dissolved ionic concentration in water, are very small (about 50 to $60 \mu \mathrm{S} / \mathrm{cm}$ ) in the headwaters of the Colorado River basin, represented by sites 1, 2, and 3 (Lake Granby, Granby Pump Canal, and Adams Tunnel). Downstream, mean specific conductance increases to about $200 \mu \mathrm{S} / \mathrm{cm}$ in the Colorado River basin (at site 10) and to about $1,600 \mu \mathrm{S} / \mathrm{cm}$ in the South Platte River basin (at site 9). Mean $\mathrm{pH}$ also increases, from about 7.1-7.5 at the headwater sites to about 8.1 at the downstream sites.

Nutrient concentrations generally were low at most sites. Mean concentrations of nitrite plus nitrate and ammonia plus organic nitrogen were less than $1 \mathrm{mg} / \mathrm{L}$ at all Colorado River basin sites $(1,2,3$, and 10), all reservoir sites $(1,5$, and 6$)$, and both tunnel sites (3 and 4). Mean concentrations for 
these nitrogen species were greater than $1 \mathrm{mg} / \mathrm{L}$ at sites on natural streams in the South Platte River basin (sites 7, 8, and 9), but maximum concentrations did not exceed $10 \mathrm{mg} / \mathrm{L}$. Mean concentrations of total and dissolved phosphorus were less than $0.1 \mathrm{mg} / \mathrm{L}$ at the Colorado River basin sites and at the tunnel sites. Mean concentrations were higher in the South Platte River basin reservoirs (sites 5 and 6 ), but still less than $0.2 \mathrm{mg} / \mathrm{L}$. At natural stream sites in the South Platte River basin, mean phosphorus concentrations ranged from about 0.4 to about $0.9 \mathrm{mg} / \mathrm{L}$. There is no State standard or Federal criterion for phosphorus; however, the U.S. Environmental Protection Agency (1986) has stated that, in order to prevent nuisance algal growth associated with accelerated eutrophication, total phosphorus concentrations should not exceed $0.025 \mathrm{mg} / \mathrm{L}$ in lakes or reservoirs and $0.1 \mathrm{mg} / \mathrm{L}$ in streams. Based on these limits, the risk of eutrophication-related water-quality problems is small in Lake Granby (site 1), moderate in Horsetooth Reservoir and Carter Lake (sites 5 and 6$)$, and substantial at the natural stream sites ( 7,8 , and 9) in the South Platte River basin.

Trace metal concentrations at headwater sites were measured in filtered samples and represent the dissolved fraction. At downstream sites, the totalrecoverable fraction was measured. The total-recoverable metal concentration of a sample is at least as large as the dissolved metal concentration. Mean concentrations of the trace metals cadmium, copper, lead, and zinc were similar in Lake Granby (site 1) and the Granby Pump Canal (site 2). The mean concentration of nickel was slightly higher in the canal than in the lake. The mean concentrations of all these trace metals were slightly lower at the Adams Tunnel (site 3), probably because of dilution by inflow from other sources to Grand Lake. Mean lead concentrations at downstream sites (5, Horsetooth Reservoir, and 10, Colorado River near Radium) were similar to those at headwater sites ( 1 and 2 ), but mean copper concentrations were higher at both downstream sites. Also, mean zinc concentration was higher at site 5 and mean nickel concentration was higher at site 10. Part or all of these increases may have resulted from measurement of the dissolved fraction at the headwater sites and the total-recoverable fraction at the downstream sites. Mean concentrations of dissolved manganese also increased downstream, from less than $3 \mu \mathrm{g} / \mathrm{L}$ at the Adams Tunnel (site 3 ) to about 20-60 $\mu \mathrm{g} / \mathrm{L}$ at natural stream sites ( 7 through 10) in the Colorado and South Platte River basins. Mean dissolved iron concentrations were similar at the Adams Tunnel (site 3 ), Horsetooth Reservoir (site 5), and Boulder Creek (site 7), but were lower further downstream on the South Platte River (sites 8 and 9), perhaps because of dilution by inflow from the main stem of the river. The concentrations of cadmium, silver, mercury, and the nonmetal trace constituents cyanide, selenium, and sulfide usually were less than detection limits at all sites that had available data.

Bacterial concentrations generally were low at sites representative of reservoir water (sites 2 through 6 ). (For bacterial analyses, site 2, Granby Pump Cana1, was considered representative of water in Lake Granby; site 3, Adams Tunnel, was considered representative of water in Grand Lake; and site 4, Olympus Tunnel, was considered representative of water in Lake Estes.) The highest median bacterial concentration at these sites was 4 colonies/100 $\mathrm{mL}$, with the exception of total coliform at site 4 , which had a median concentration of 59 colonies $/ 100 \mathrm{~mL}$. The median is more representative of the center of data for bacterial data because it is unaffected by the few large outliers 
that commonly occur in these data. Median bacterial concentrations were high (greater than 100) only at sites 7 and 8 (Boulder Creek and South Platte River at Masters), both of which are downstream from municipal wastewater-treatment plants.

Comparison of State standards and percentile values indicate few instances for which a standard was exceeded in more than 25 percent of samples. The most frequent occurence of exceedance was for copper in Horsetooth Reservoir (site 5), where the standard was exceeded in more than 50 percent of the surface samples and more than 75 percent of the bottom samples. Other frequent occurences of standard exceedence included manganese and fecal coliform at site 7 on Boulder Creek and copper and iron at site 10 on the Colorado River near Radium. Exceedence of standards in less than 25 percent of the samples was more common. The $\mathrm{pH}$ was less than the minimum standard at least once at all headwater, tunnel, and reservoir sites (1 through 6). Copper and lead standards were exceeded at sites 1,2 , and 3 , which represent water-quality in Lake Granby and Grand Lake, and at site 10 on the Colorado River near Radium. The lead standard also was exceeded in Horsetooth Reservoir. The apparent exceedences of the ammonia, cadmium, mercury, and silver standards at various sites are not definitive. The ammonia standard is for the un-ionized form, which would be less than the reported ionic concentrations under most $\mathrm{pH}$ and temperature conditions at these sites. The standards for cadmium, mercury, and silver are all less than the reported detection limits, so any detected value exceeds the standard. Detectable concentrations occurred in less than 50 percent of all samples with analyses for cadmium or mercury and in less than 5 percent of samples with analyses for silver.

\section{Trend Analysis}

Trend analyses of time-series data for water-quality properties and constituents are complicated by several common characteristics of these data sets: Nonnormality, seasonality, serial dependence, and censoring. The seasonal Kendall test is a technique unaffected by these characteristics (Hirsch and others, 1982; Hirsch and Slack, 1984). This technique is used to identify significant monotonic changes in the data over time. It also provides an estimate of the slope of the change in the median value, which can be used to calculate the percentage change in median value during the period of record. The seasonal Kendall test is nonparametric; the test statistic is determined by using ranks of the data rather than actual data values. Censored values and nonnormality do not affect rank. Trends are evaluated separately for each specified season (usually months), and results are combined into a single test statistic ( $t a u)$. The significance level ( $p$-value) of the test statistic then is adjusted to account for serial correlation. The seasonal Kendall test used in this study was based on methods developed by the U.S. Geological Survey (Hirsch and Slack, 1984).

In addition to testing the original data from natural streamflow sites, the seasonal Kendall test also was used to identify trends in the time series of flow-adjusted concentrations. Flow adjustment was used to eliminate the effect of correlation between streamflow and water-quality property or constituent values. This adjustment decreases the possibility of misinterpreting the significance of a trend in water quality that results only from a change 
in streamflow during the period of record. Flow-adjusted concentration, in this study, was defined to be the residual (actual minus estimated value) based on linear regression between the logarithm of streamflow and the logarithms of each property or constituent. (Actual $\mathrm{pH}$ was used because it is already a logarithm.)

The seasonal Kendall test was applied to identify trends in the time series of each property and constituent at each site. The seasonal division was defined to be monthly for the streamflow sites. Because of less frequent sampling at the reservoir sites, the seasonal division was defined to be three per year (May, July, and September) for Horsetooth Reservoir and Carter Lake (sites 5 and 6), and annually (no seasonal differences) for Lake Granby (site 1 ).

Results of the trend analyses are given for each site in tables 29 through 38 (in the "Hydrologic Data" section at the back of this report). Individual properties or constituents were included in these tables only if the data contained the following characteristics:

1. At least 5 years of record.

2. At least 10 values greater than or equal to the detection limit for streamflow sites $(2,3,4$, and 7 through 10$)$, or at least 5 values greater than or equal to the detection limit for reservoir sites $(1,5$, and 6$)$.

3. No more than 10 percent of values less than the detection limit for streamflow sites, or no more than 25 percent of values less than the detection limit for reservoir sites.

The criteria were less stringent for reservoir sites because these sites had fewer available data.

Several significance levels are reported. The significance level unadjusted for serial correlation is reported for all trends. If the period of record is 10 years or longer, the adjusted significance level also is reported. In general, the adjusted value will be larger, which indicates less significance, because there is less information in serially correlated data. The difference between the unadjusted and adjusted values increases with the strength of the serial correlation. Adjusted values are not reported for Lake Granby (site 1) because the annual seasonal division was large enough to preclude serial correlation.

For natural streamflow sites, the significance level of trends in flowadjusted concentration (FAC) also is listed. This FAC significance level is adjusted for serial correlation if the period of record is 10 years or longer. Trends in FAC are listed only if the regression model produced a good fit, which was defined to be a significant F-statistic ( $p$ less than 0.01 ) and a coefficient of determination ( $r$-squared) greater than 0.4 . No models met these criteria for data from the South Platte River at Masters (site 8 ) or the Colorado River near Radium (site 10); therefore, significance levels for FAC are listed only for Boulder Creek (site 7) and the South Platte River near Weldona (site 9). 
The trend slope listed in tables 29 through 38 is the seasonal Kendall slope estimator, defined by Hirsch and others (1982). It is the median of all possible differences in the time-series data within the same seasons, and provides an estimate of the median annual change in the data. The overall change during the period of record can be expressed as a percentage of the estimated median for the first year of record:

$$
d(M)=100 \frac{n T}{M-\frac{T(n+1)}{2}}
$$

where $d(M)=$ the change in median as a percentage of the estimated median for the first year of record;

$\mathrm{n}=$ the number of years of record;

$\mathrm{T}=$ the trend slope, in units per year; and

$M=$ the overall median, in units of the property or constituent.

This overall change in median is useful in judging the relative importance of the annual change expressed by the trend slope.

In instances where the data were highly skewed, a trend is unlikely to be linear; therefore, the trend slope estimator computed from actual data values is not appropriate. Transforming to logarithms will linearize the trend if the annual changes are proportional. The significance of the trend, which is based on ranks of the data, is not affected by this transformation. Logarithms were used for trend analyses of all bacterial data, of total phosphorus concentrations at the reservoir sites $(1,5$, and 6$)$, and of dissolved manganese concentration in Horsetooth Reservoir (site 5). The trend slope reported for these constituents is the multiplicative change in median value each year. The change in median has been detransformed and is the overall change as a percentage of the estimated median for the first year of record in the original data units.

Significant trend slopes are identified in tables 29 through 38 based on the following criteria:

1. Moderately significant (*), if the significance level was less than or equal to 0.1 and greater than 0.05 .

2. Significant $(* *)$, if the significance level was less than or equal to 0.05 and greater than 0.01 .

3. Very significant (***), if the significance level was less than or equal to 0.01 .

The choice of significance level used in this identification, if more than one was reported for a property or constituent, was based on the order: (1) Significance level of flow-adjusted concentration, (2) significance level adjusted for serial correlation, and (3) unadjusted significance level. 
A summary of significant trends at all sites is listed in table 3. Several general observations about trends in the study area can be made from the results in this table. Specific conductance has decreased at the Colorado River basin headwater sites $(1,2$, and 3 ). This decrease may have affected specific conductance downstream at the olympus Tunnel (site 4), Carter Lake (site 6), and the South Platte River near Weldona (site 9). Decreases in dissolved-solids concentrations were associated with the trends in specific conductance at these downstream sites. This result is expected because the dissolved ionic solids impart electrical conductance to the water. Decreasing trends also were identified in many of the concentrations of the major ionic constituents at sites 4 and 9 . The average change in median dissolved-solids (sum of constituents) concentration at site 4 was about $-0.3 \mathrm{mg} / \mathrm{L}$ per year, a decrease of about 14 percent for the 13 years of record (table 32). The average change in median dissolved-solids concentration at site 9 was about $-27 \mathrm{mg} / \mathrm{L}$ per year, a decrease of about 31 percent for the 16 years of record (table 37). The magnitude and significance of the decreases at site 9 indicate that the trends in CBT Project delivery water, represented by trends at site 4 , are not the sole cause of trends downstream in the South Platte River. The largest component of the decrease in dissolved-solids concentration at site 9 was the decrease in dissolved sulfate concentration. Because sulfate commonly is associated with agricultural return flow, the trends at site 9 may be due to changes in irrigation practices in the South Platte River valley. An increasing trend in specific conductance was identified only for the Colorado River near Radium (site 10). This site is downstream from the CBT Project and other diversions from the Colorado River basin. The increasing trend may indicate that these diversions are affecting water quality in the basin by removing water that has a low dissolved-solids concentration from the headwater areas, thereby decreasing the dilution of higher concentrations from downstream inflows. The average annual change in median dissolved-solids concentration (sum of constituents) at site 10 was $4.4 \mathrm{mg} / \mathrm{L}$, an increase of about 26 percent for the 7 years of record (table 38).

Trends in nutrient data were not as easy to interpret. Concentrations of nitrite plus nitrate increased significantly at three natural streamflow sites (7, Boulder Creek; 8, South Platte River at Masters; and 9, South Platte River near Weldona). At site 8 , analyses of nitrite plus nitrate were made on filtered samples during the first half of the period of record, and then were changed to unfiltered samples. Although most nitrite plus nitrate in surface water is dissolved and would pass through a filter, the change in sample preparation could have affected the trend results. The only other trends in nitrogen species were significant decreases in concentrations of ammonia plus organic nitrogen in the South Platte River at Masters (site 8) and the Colorado River near Radium (site 10). The primary changes in phosphorus concentration were decreases at the reservoir sites ( 1 , Lake Granby; 5 , Horsetooth Reservoir; and 6, Carter Lake). The significant decreases in total phosphorus concentration at these sites ranged/from about 87 to 94 percent (tables 29, 33, and 34). The nearly 65 percent decrease in total phosphorus concentration at site 2 (Granby Pump Canal, table 30) probably is related to the similar decrease in Lake Granby, which is the source of the water in the canal. These trends in phosphorus concentration at the reservoir sites indicate a smaller risk of eutrophication-related water-quality problems than was estimated based only on summary statistics. The seemingly anomalous decrease 


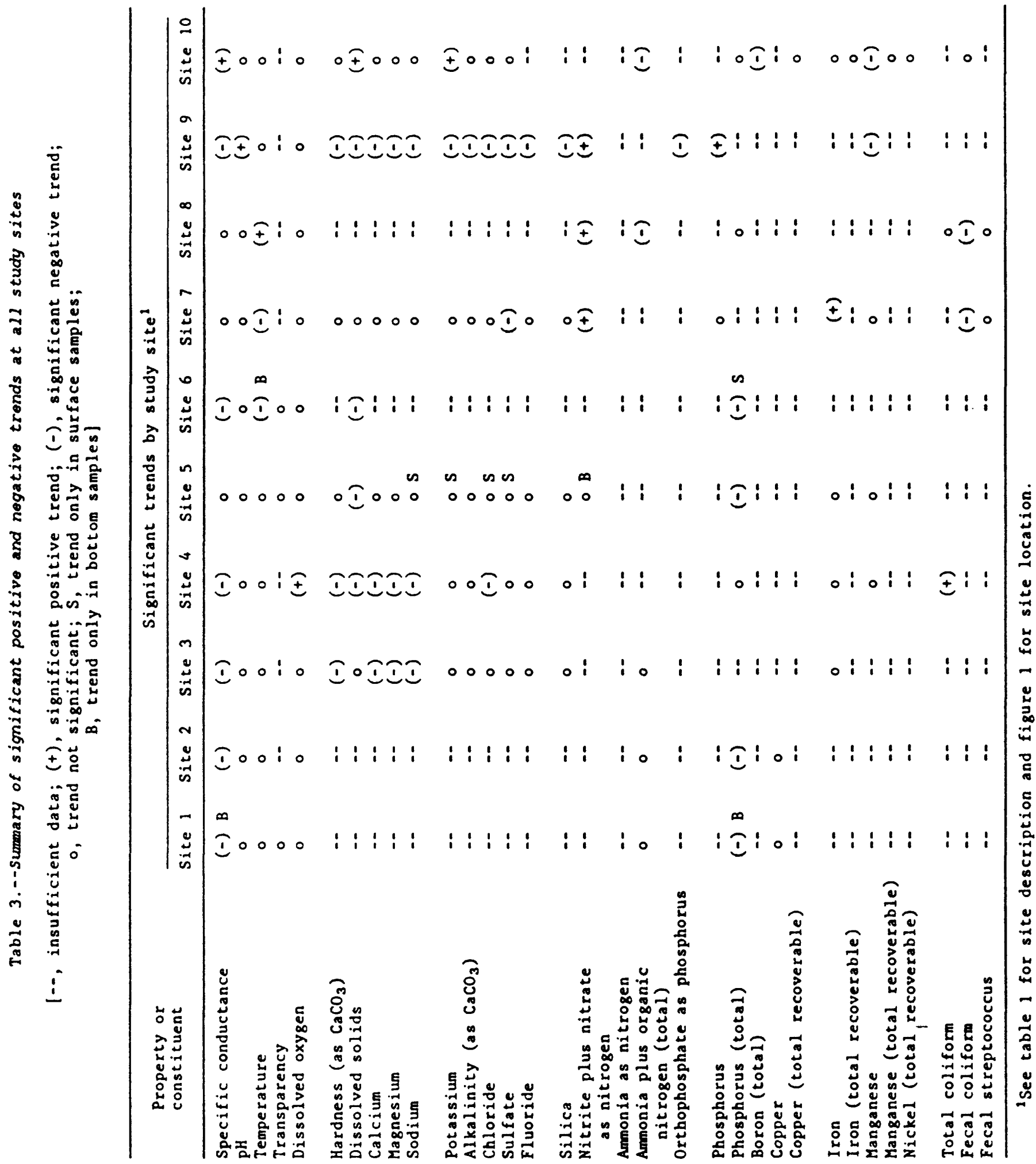


in orthophosphate concentration and increase in phosphorus concentration at site 9 (South Platte River near Weldona) likely occurred because the periods of record were different: 1972-78 for orthophosphate and 1979-87 for phosphorus (table 37 ).

Few significant trends were identified for trace constituent concentrations. The most prominent were a $4 \mu \mathrm{g} / \mathrm{L}$ per year increase in iron at site 7 (Boulder Creek, table 35), a $2.4 \mu \mathrm{g} / \mathrm{L}$ per year decrease in manganese at site 9 (South Platte River near Weldona, table 37 ), and a $7.5 \mu \mathrm{g} / \mathrm{L}$ per year decrease in boron at site 10 (Colorado River near Radium, table 38). A moderately significant trend also was identified for manganese at site 10 , but the trend slope was estimated to be zero. This result indicates that negative differences were more numerous than positive differences, but most differences were zero.

Significant decreases in concentrations of fecal coliform bacteria were identified at sites 7 (Boulder Creek) and 8 (South Platte River at Masters). Both these sites are downstream from municipal wastewater-treatment plants, and plant improvements could account for the decreased bacterial concentrations. At site 7, the median concentration decreased 80 percent from 1980 to 1987 (table 35). At site 8, the median concentration decreased about 96 percent from 1982 to 1987 (table 36). The largest percentage change in any property or constituent in the entire data set was the 1,000-percent increase in total coliform bacteria at site 4 (0lympus Tunnel, table 32). However, during the 15 years of record, the estimated median value at this site increased from about 16 to about 180 colonies $/ 100 \mathrm{~mL}$, which makes the increase large only because the initial value was so small.

\section{ANALYSIS OF SAMPLING PROGRAMS}

Evaluation of the water-quality sampling program in the District and CBT Project areas involved three processes. Selected sites were compared to determine whether they were providing essentially the same information. Then, the sampling frequency was evaluated at all sites considered for continuation. Finally, the schedule of laboratory analyses was assessed in terms of intended uses of the data by the project cooperators. No attempt was made to determine whether additional stations would be necessary for complete areal assessment of water quality within the study area.

\section{Comparison of Selected Sites}

Two pairs of sites were selected for comparison: Sites 3 and 4 (the Adams and Olympus Tunnels), and sites 8 and 9 (the South Platte River at Masters and near Weldona). The sites in each pair were located in close proximity and shared the same primary source of water. Site comparisons were made by using ordinary least-squares regression. The regressions tested the ability to estimate property and constituent values at the site with the shorter period of record (sites 4 and 8 ) based on data from the other site (3 and 9). Data pairs were defined as samples collected during the same month. Only detected values were included. An example regression plot of nitrite plus nitrate data from sites 8 and 9 is displayed in figure 5 . 


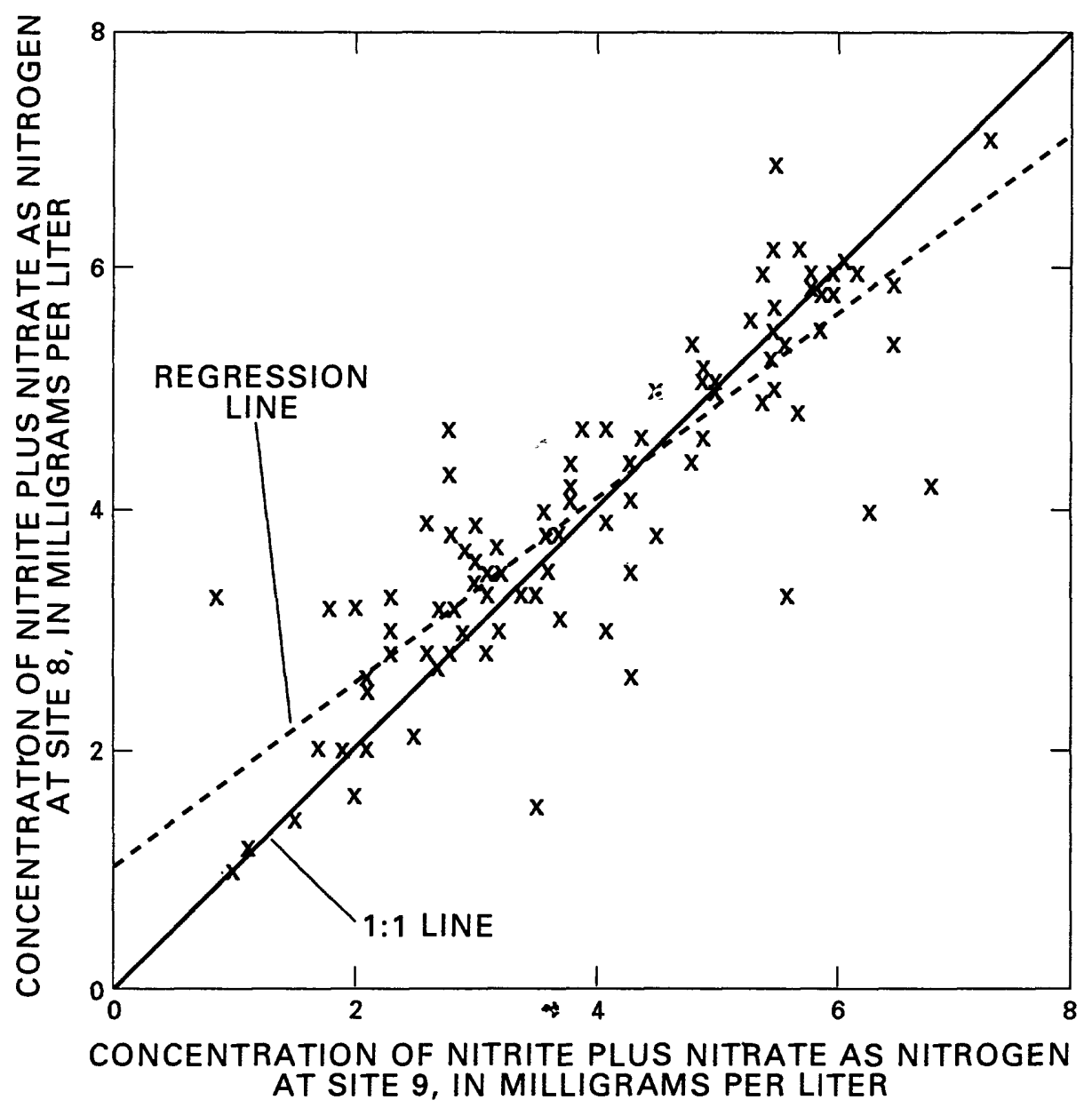

Figure 5.--Example of regression plot comparing data from two sites.

Comparisons for each property and constituent having paired data were evaluated based on significance and accuracy of the regression model. If the data sets were approximately identical, the regression line would not be significantly different from the 1:1 line; therefore, the slope of the regression line would be about 1 , and the intercept would be about 0 . Tests for these two conditions were included in the regression analysis. Model significance also was judged by the coefficient of determination ( $r$-squared), which is a measure of the linear relation between the data sets, and by the overall F-statistic, which is a measure of the ability of the model to estimate data at one site based on data at the other site. If the same information is contained in the data sets at each site, the coefficient of determination should be about 1.0 , and the significance level of the F-statistic should be nearly zero. Furthermore, the accuracy of a regression model is determined by the standard error (root mean-square error). In this analysis, standard errors were computed as a percentage of the mean value of the property or constituent data included in the model for the site with the shorter period of record (sites 4 and 8 ).

Results for the comparison of data from the Adams and 0lympus Tunnels (sites 3 and 4) are listed in table 4. Water from the Adams Tunnel flows into Lake Estes, where it is mixed with natural inflow from the Big Thompson River and released into the 0lympus Tunnel (figs. 3 and 4). Models were very significant (significance level less than 0.01) for all tested properties and constituents except dissolved phosphorus and fecal coliform bacteria. 


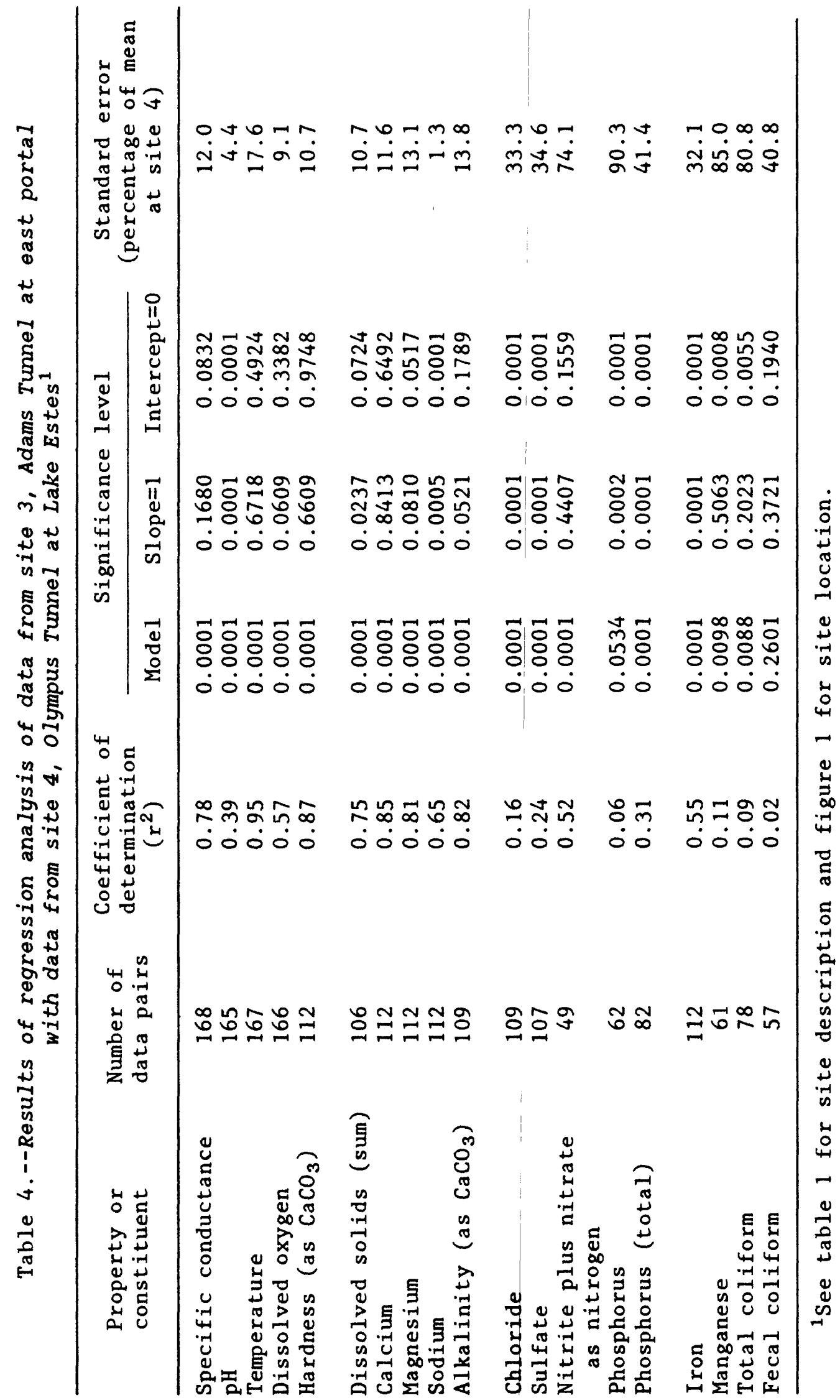


However, the coefficients of determination also were small for chloride, sulfate, total phosphorus, manganese, and total coliform. Based on the large significance levels for the tests of slope and intercept, the data were nearly identical for specific conductance, temperature, dissolved oxygen, hardness, dissolved solids, calcium, magnesium, and alkalinity. The data for $\mathrm{pH}$ and sodium were not identical, but the standard error of the model was small. If sampling was discontinued at site 4 on the 0lympus Tunnel, some information about nutrient, trace metal, and bacterial concentrations would be lost. Because concentrations of all these constituents generally are low (table 6), the loss of information may not be critical. Information about physical properties, most major ions, and some nutrients and trace metals could be obtained from data at site 3 on the Adams Tunnel.

Results of the comparison of data between sites 8 and 9 on the South Platte River (at Masters and near Weldona) are listed in table 5. Site 9 is 21 river miles downstream from site 8 (fig. 1). There is little natural tributary inflow between the two sites, but there are several sources of ground-water inflow, primarily from irrigation in the alluvial valley (Minges, 1983). There also are two major diversions that can substantially decrease the flow between the two sites during the irrigation season, generally April through October. Regression models for all tested properties and constituents were very significant (significance level less than 0.01 ). The data for temperature, dissolved oxygen, sodium, alkalinity, and chloride at the two sites were essentially identical (significance levels for slope and intercept greater than 0.01). The coefficients of determination were large for all models except $\mathrm{pH}$ and manganese, and the standard error was large only for manganese. The standard error of estimated $\mathrm{pH}$ was very smal1 (2 percent), probably because of the narrow range of values (about $1.0 \mathrm{pH}$ unit) and large mean values (about 8.0 ) at both sites. With the possible exception of the trace metals, little information is provided from the data at site 8 that is not available from the data at site 9 .

\section{Sampling Frequency at Streamflow Sites}

Sampling frequency during the period of record for this study (through water year 1987) was approximately monthly at most streamflow sites. The only exceptions were site 2 (Granby Pump Canal), which was visited monthly but only sampled when water was flowing, and site 10 (Colorado River near Radium), where monthly samples were collected only from March or April through November. The data sets from streamflow sites 2 (Granby Pump Canal), 3 (Adams Tunne1), 7 (Boulder Creek), 9 (South Platte River near Weldona), and 10 (Colorado River near Radium) were analyzed to determine whether sampling frequency could be decreased to bimonthly or quarterly without loss of information. If the distributional characteristics of the data set were preserved in a specified subset of the data, the information loss was considered negligible. Two subsets were used to test bimonthly sampling: (subset 1) Data collected in oddnumbered months (January $=1$ ), and (subset 2) data collected in even-numbered months. Three subsets were used to test quarterly sampling: (subset 1) Data collected in January, April, July, and October; (subset 2) data collected in February, May, August, and November; and (subset 3) data collected in March, June, September, and December. Sites 4 (Olympus Tunnel) and 8 (South Platte River at Masters) were not included in this analysis because of their similarities to sites 3 (Adams Tunnel) and 9 (South Platte River near Weldona). 


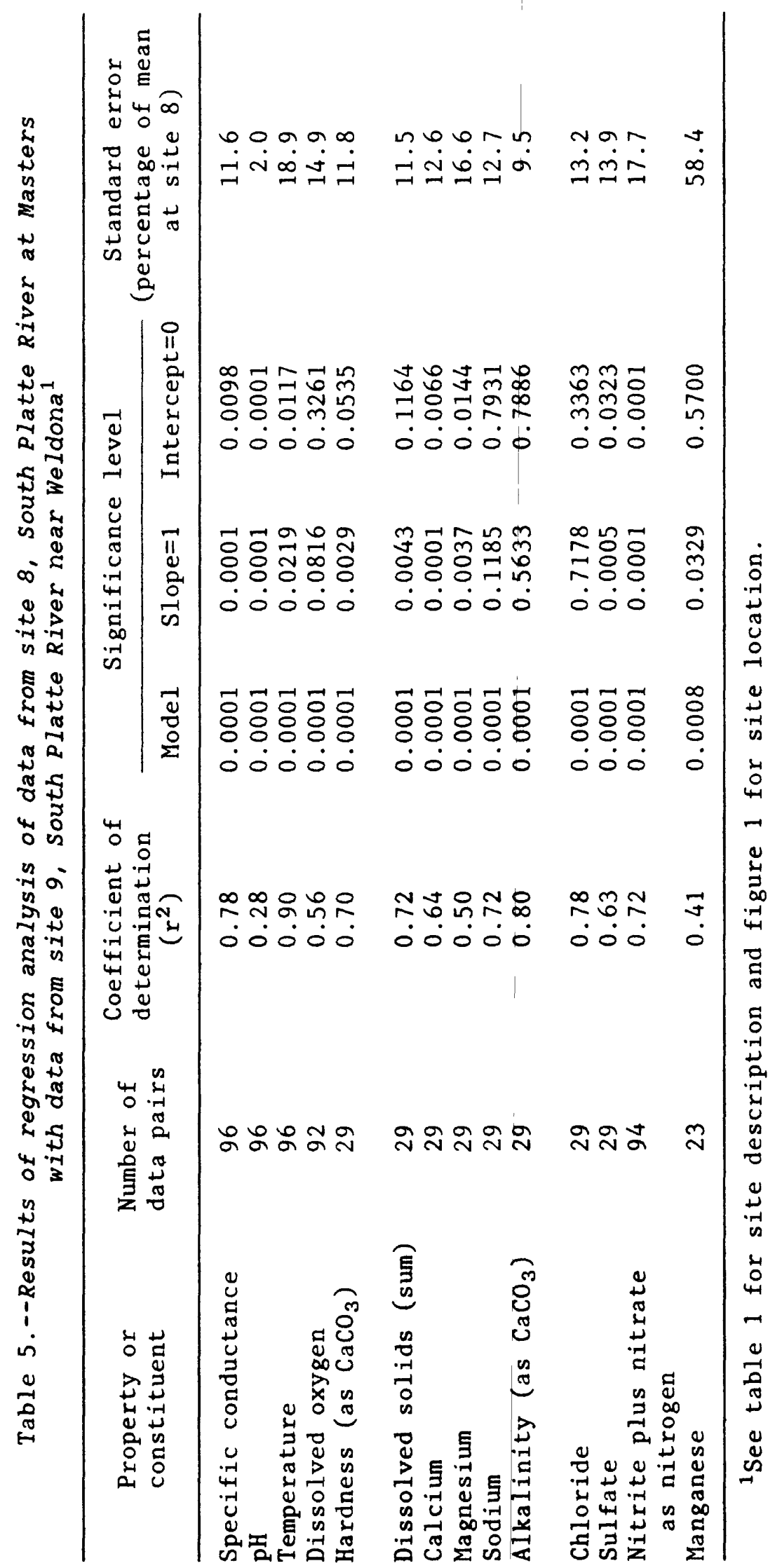


Two primary characteristics of a data distribution are central location, usually described by the mean or median, and spread, usually described by the variance. In this study, nonparametric statistical methods were used to test for differences in the median and spread of subsets of water-quality data associated with decreased sampling frequency. Differences between two medians were identified by using a student's t-test on the ranks of the data, which is equivalent to the nonparametric Wilcoxon-Mann-Whitney test (Conover and Iman, 1981). Differences among more than two medians were tested by analysis-ofvariance on ranks of the data, which is equivalent to the Kruskal-Wallis test. Differences in spread were identified by using the squared-ranks test (Conover, 1980). Because these tests require independence of the tested data sets, the bimonthly and quarterly subsets could not be compared directly to the full (monthly) data set. The two bimonthly subsets (and three quarterly subsets) were compared to each other, and the test results indicated whether the subset distributions were significantly different.

Streamflow at time of sampling was included in this analysis to indicate whether differences in property or constituent distributions might be related to differences in the sampled flow regime. If differences in streamflow were identified, the distribution of data collected at a decreased sampling frequency would be dependent on the sampling schedule. In this circumstance, decreasing the sampling frequency is not appropriate.

The water-quality properties and constituents included in this analysis were selected to represent onsite measurements ( $\mathrm{pH}$, temperature, and dissolved oxygen), major dissolved constituents (hardness, dissolved solids, chloride, and sulfate), nutrients (nitrite plus nitrate and phosphorus), trace metals (copper, iron, manganese, and nickel), and bacteria (fecal coliform). Data for the properties or constituents selected within each of these groups were available from most streamflow sites; therefore, the selected properties and constituents also represent a common data set for the sites.

Results of the tests on median and spread were verified visually by producing side-by-side box plots of the data distributions for the full (monthly) data sets and all bimonthly and quarterly subsets. Box plots display a variety of distributional characteristics of a data set, including the median, upper and lower quartiles, and range (fig. 6). The rectangular box delineates the interquartile range, which encompasses the central half of the data, and gives an indication of the spread. Placed side-by-side, box plots provide a visual indication of differences in data distributions.

A second test for loss of information at streamflow sites was a comparison of trend-analysis results from the monthly data set and the data subsets associated with decreased sampling frequencies. The significance of trends in the bimonthly and quarterly data subsets were evaluated using the seasonal Kenda11 procedure and compared to significance levels determined for the entire data set. If trends were determined to be significant in the monthly data but not significant in a particular data subset, decreasing the sampling frequency could result in a loss of information. There would be little loss of information if trends that were significant in the monthly data were also determined to be significant in each data subset for a particular sampling frequency. Detection of additional or changing trends in future data could require a longer period of record if sampling frequency is decreased. However, for this study, preservation of monthly trends in data subsets was considered sufficient justification to consider decreasing the sampling frequency. 


\title{
EXPLANATION
}

\author{
- Far out value \\ (greater than 3 times IQR)
}

\section{Outside value
(greater than 1.5 times IQR)}

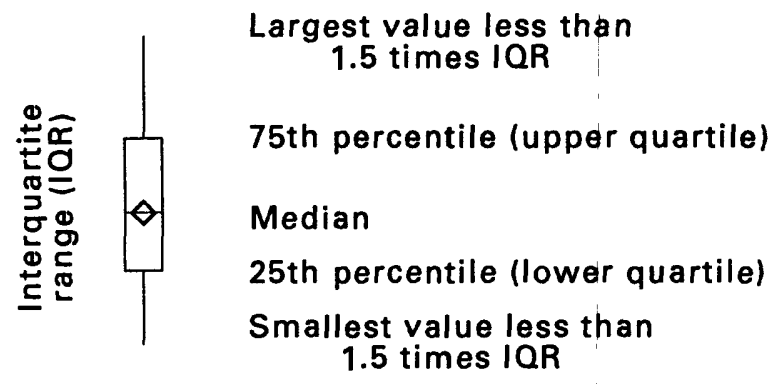

Figure 6.--Example diagram of a box plot.

Trends were determined for all properties and constituents that met the minimum criteria for the seasonal Kendall analysis. For each site, the properties and constituents included in the trend analysis were not necessarily the same as those included in the tests for difference in median and spread.

Results of the analyses of sampling frequency for site 2, Granby Pump Canal, are presented in table 6 and figure 7. The numbers in table 6 represent the probability that characteristics of the two bimonthly subsets or the three quarterly subsets are not different. If the probability value is less than or equal to 0.10 , the difference between subsets is at least moderately significant.

The significance tests indicated no differences in the median and spread of the bimonthly data subsets for any property or constituent. Box plots of $\mathrm{pH}$, temperature, dissolved oxygen, nitrite plus nitrate, total phosphorus, and copper distributions shown in figure 7 also support this conclusion, and further indicate little difference between either bimonthly subset and the full data set. A moderately significant difference in median values was identified for the quarterly subsets of temperature. This difference is clearly shown by the box plots. Additional differences between the distribution of the full data set and the quarterly subsets were apparent on the box plots for nitrite 
Table 6.--Significance of differences in water-quality properties and constituents among selected bimonthly and quarterly sampling schedules at site 2, Granby Pump Canal near Grand Lake

["Significance level" represents the probability that the indicated characteristic is not different between data subsets]

\begin{tabular}{|c|c|c|c|c|c|}
\hline \multirow{3}{*}{$\begin{array}{l}\text { Property } \\
\text { or } \\
\text { constituent }\end{array}$} & \multirow{3}{*}{$\begin{array}{l}\text { Number } \\
\text { of } \\
\text { samples }\end{array}$} & \multicolumn{4}{|c|}{ Significance level } \\
\hline & & \multicolumn{2}{|c|}{ Bimonthly } & \multicolumn{2}{|c|}{ Quarterly } \\
\hline & & Median & Spread & Median & Spread \\
\hline Streamflow & 102 & 0.36 & 0.23 & 0.38 & 0.59 \\
\hline pH & 98 & 0.74 & 0.19 & 0.53 & 0.99 \\
\hline Temperature & 102 & 0.70 & 0.47 & $0.08 *$ & 0.59 \\
\hline Dissolved oxygen & 100 & 0.98 & 0.47 & 0.85 & 0.35 \\
\hline $\begin{array}{l}\text { Nitrite plus nitrate } \\
\text { as nitrogen }\end{array}$ & 64 & 0.50 & 0.43 & 0.29 & 0.49 \\
\hline Phosphorus (total) & 70 & 0.83 & 0.59 & 0.91 & 0.76 \\
\hline Copper & 36 & 0.97 & 0.24 & 0.65 & 0.78 \\
\hline Nickel & 36 & 0.69 & 0.16 & 0.54 & 0.55 \\
\hline
\end{tabular}

1 See table 1 for site description and figure 1 for site location.

* Moderately significant, significance level less than or equal to 0.1 . and greater than 0.05 .

** Significant, significance level less than or equal to 0.05 and greater than 0.01 .

$* *-*$ Very significant, significance level less than or equal to 0.01 .

plus nitrate and for copper. Comparison of trend-analysis results was not particularly conclusive at this site because only a few properties and constituents had sufficient data (table 7). The trend in specific conductance was preserved in all the tested sampling frequencies, but the trend in phosphorus was identified only in one of the quarterly data subsets. In general, decreasing the sampling frequency to bimonthly would not cause a substantial loss of information, but a decrease to quarterly sampling would not be appropriate.

At site 3, Adams Tunnel, the only significant difference identified between the bimonthly data subsets was in the median concentrations of nitrite plus nitrate (table 8). However, the box plots (fig. 8) show that this difference was small and that neither bimonthly median was much different from the monthly median. Also, in the monthly and in both bimonthly distributions, 75 percent of the data are at or less than the detection limit. Moderately 

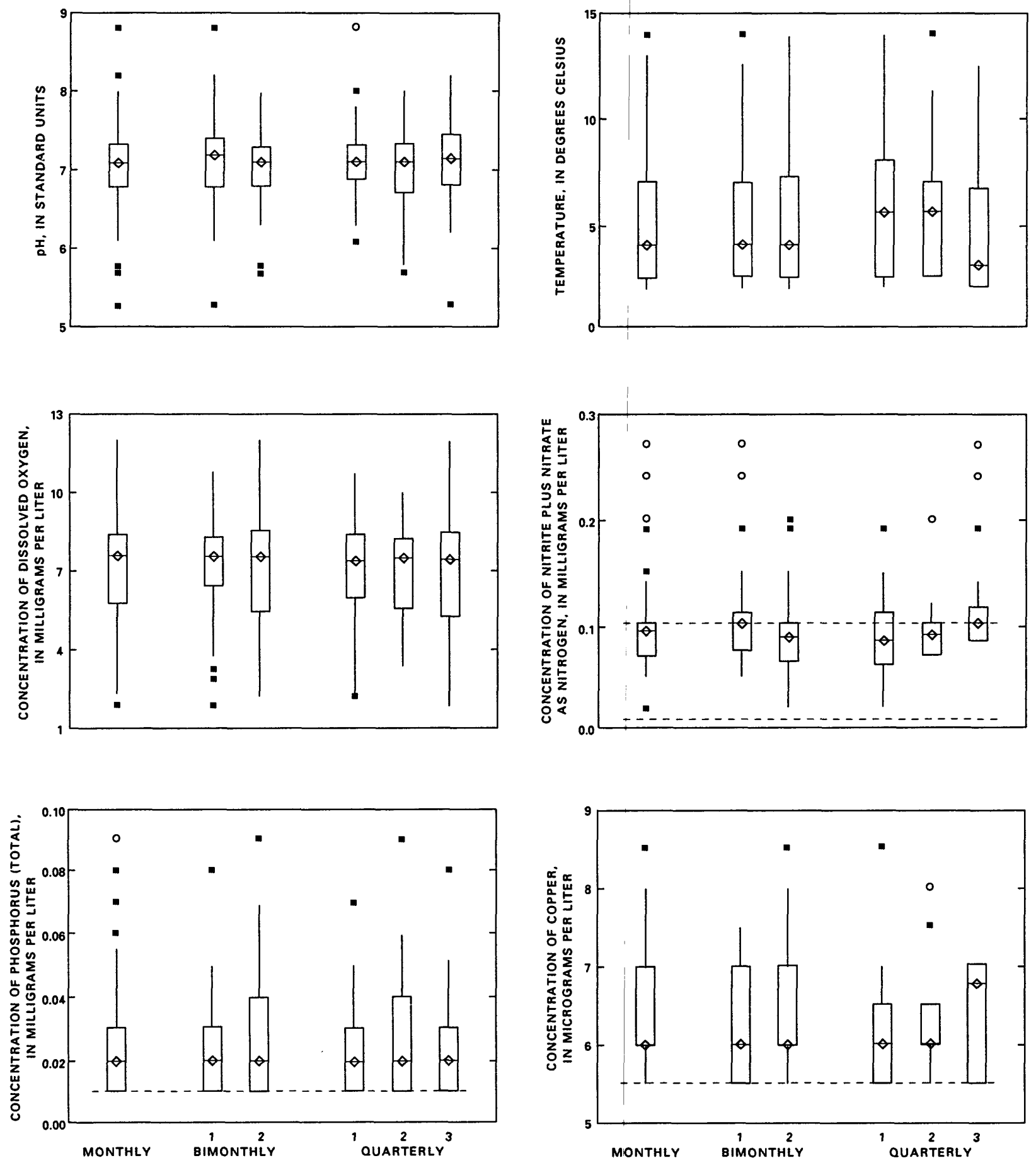

Figure 7.--Selected data distributions for various sampling frequencies at site 2, Granby Pump Canal near Grand Lake (dashes indicate detection limits). 


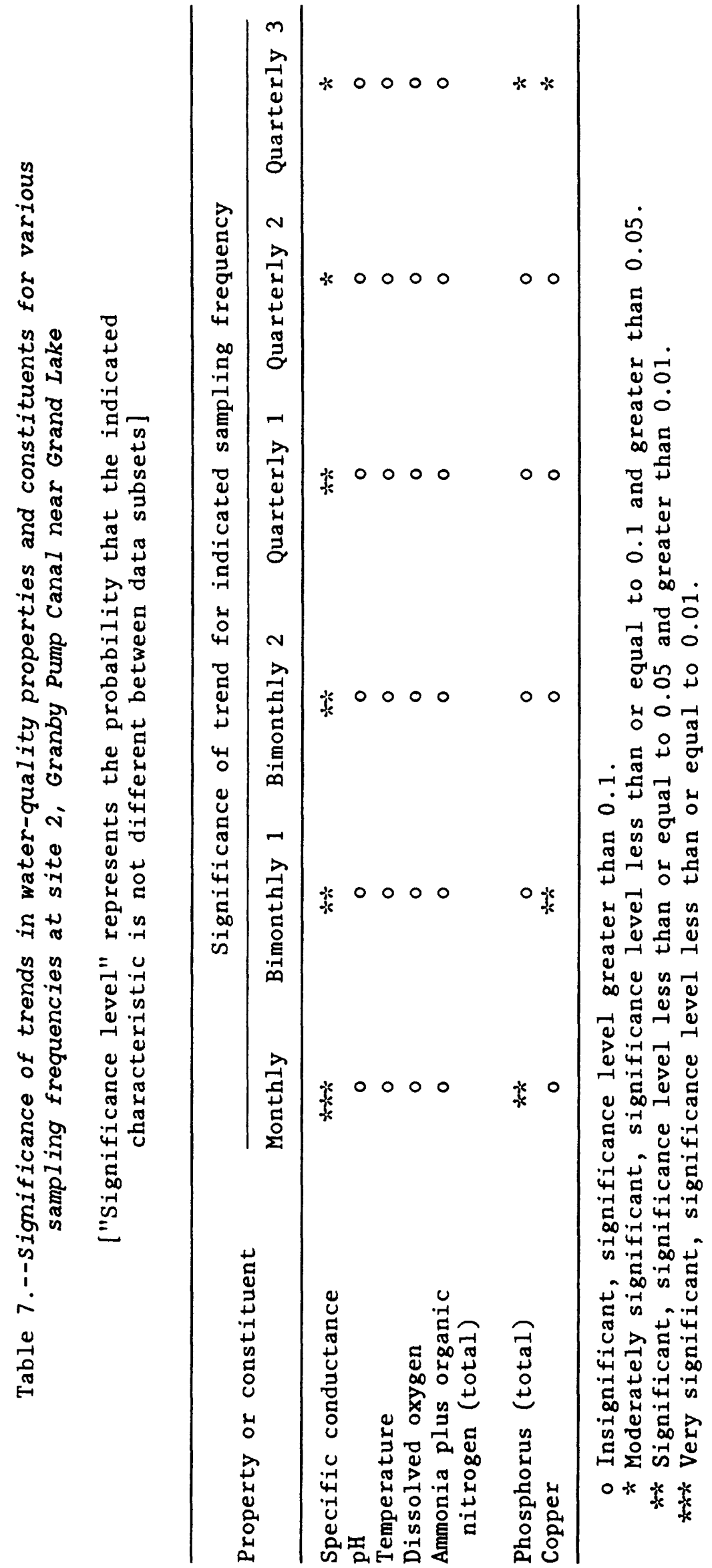


Table 8.--Significance of differences in water-quality properties and constituents among selected bimonthly and quarterly sampling schedules at site 3 , Adams Tunnel at east porta $1^{1}$

["Significance level" represents the probability that the indicated characteristic is not different between data subsets]

\begin{tabular}{|c|c|c|c|c|c|}
\hline \multirow{3}{*}{$\begin{array}{l}\text { Property } \\
\text { or } \\
\text { constituent }\end{array}$} & \multirow{3}{*}{$\begin{array}{l}\text { Number } \\
\text { of } \\
\text { samples }\end{array}$} & \multicolumn{4}{|c|}{ Significance level } \\
\hline & & \multicolumn{2}{|c|}{ Bimonthly } & \multicolumn{2}{|c|}{ Quarterly } \\
\hline & & Median & Spread & Median & Spread \\
\hline Streamflow & 181 & 0.85 & 0.65 & 0.16 & 0.43 \\
\hline $\mathrm{pH}$ & 178 & 0.30 & 0.40 & 0.98 & 0.78 \\
\hline Temperature & 181 & 0.49 & 0.75 & 0.91 & 0.24 \\
\hline Dissolved oxygen & 179 & 0.30 & 0.33 & 0.53 & 0.25 \\
\hline Hardness (as $\mathrm{CaCO}_{3}$ ) & 115 & 0.54 & 0.42 & 0.77 & 0.25 \\
\hline Dissolved solids & 112 & 0.52 & 0.25 & 0.94 & $0.07 *$ \\
\hline Chloride & 113 & 0.30 & 0.12 & 0.29 & 0.57 \\
\hline Sulfate & 113 & 0.60 & 0.76 & 0.77 & 0.52 \\
\hline $\begin{array}{l}\text { Nitrite plus nitrate } \\
\text { as nitrogen }\end{array}$ & 115 & $<0.01 * x+6$ & 0.69 & $0.03 \div-6$ & 0.25 \\
\hline Phosphorus & 89 & 0.71 & 0.74 & 0.67 & 0.26 \\
\hline Phosphorus (total) & 97 & 0.91 & 0.75 & 0.22 & $0.08 *$ \\
\hline Copper & 35 & 0.64 & 0.32 & $0.02 x+x$ & $0.05 *$ \\
\hline Iron & 115 & 0.56 & 0.46 & 0.59 & 0.31 \\
\hline Manganese & 115 & 0.34 & 0.46 & $0.09 *$ & 0.39 \\
\hline Nickel & 35 & 0.90 & 0.34 & 0.35 & $0.07 *$ \\
\hline Fecal coliform & 98 & 0.19 & 0.84 & 0.78 & 0.43 \\
\hline
\end{tabular}

1 See table 1 for site description and figure 1 for site location.

* Moderately significant, significance level less than or equal to 0.1 and greater than 0.05 .

** Significant, significance level less than or equal to 0.05 and greater than 0.01 .

*** Very significant, significance level less than or equal to 0.01 .

significant or significant differences among the median and spread of quarterly data subsets were identified for 6 of the 16 tested properties and constituents (table 8 ). These differences are most obvious in the box plots of dissolved solids, copper, and nickel (fig. 8). Quarterly differences are not as obvious in the plots of total phosphorus and manganese. All five significant or very significant trends identified in the monthly data were preserved in one of the bimonthly data subsets (table 9), although the levels of significance were different for two of the trends. In the second bimonthly data subset, four of these five trends can be identified; however, one additional trend, in temperature, also was identified. In the quarterly data 

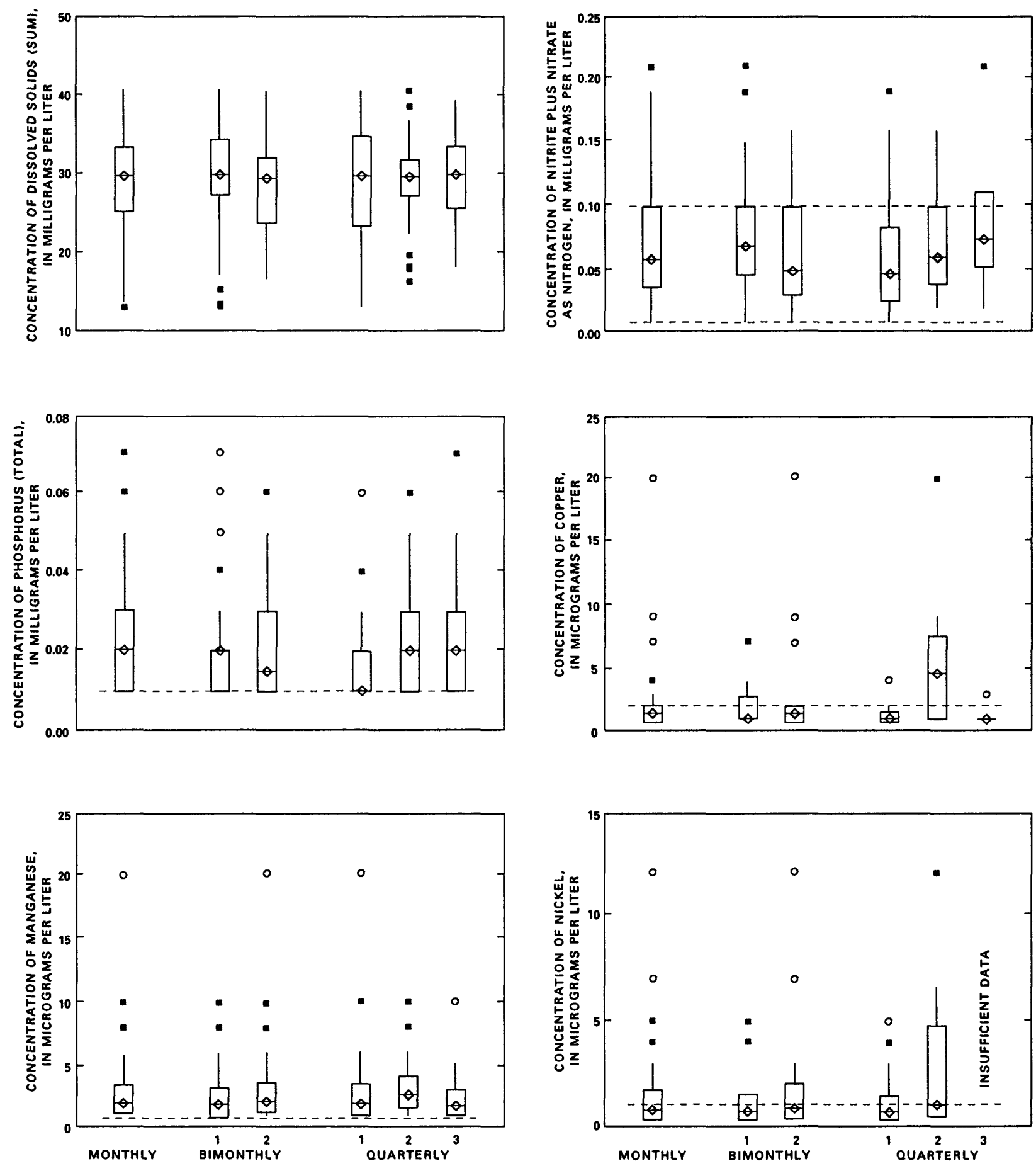

Figure 8.--Selected data distributions for various sampling frequencies at site 3, Adams Tunnel at east portal (dashes indicate detection limits). 


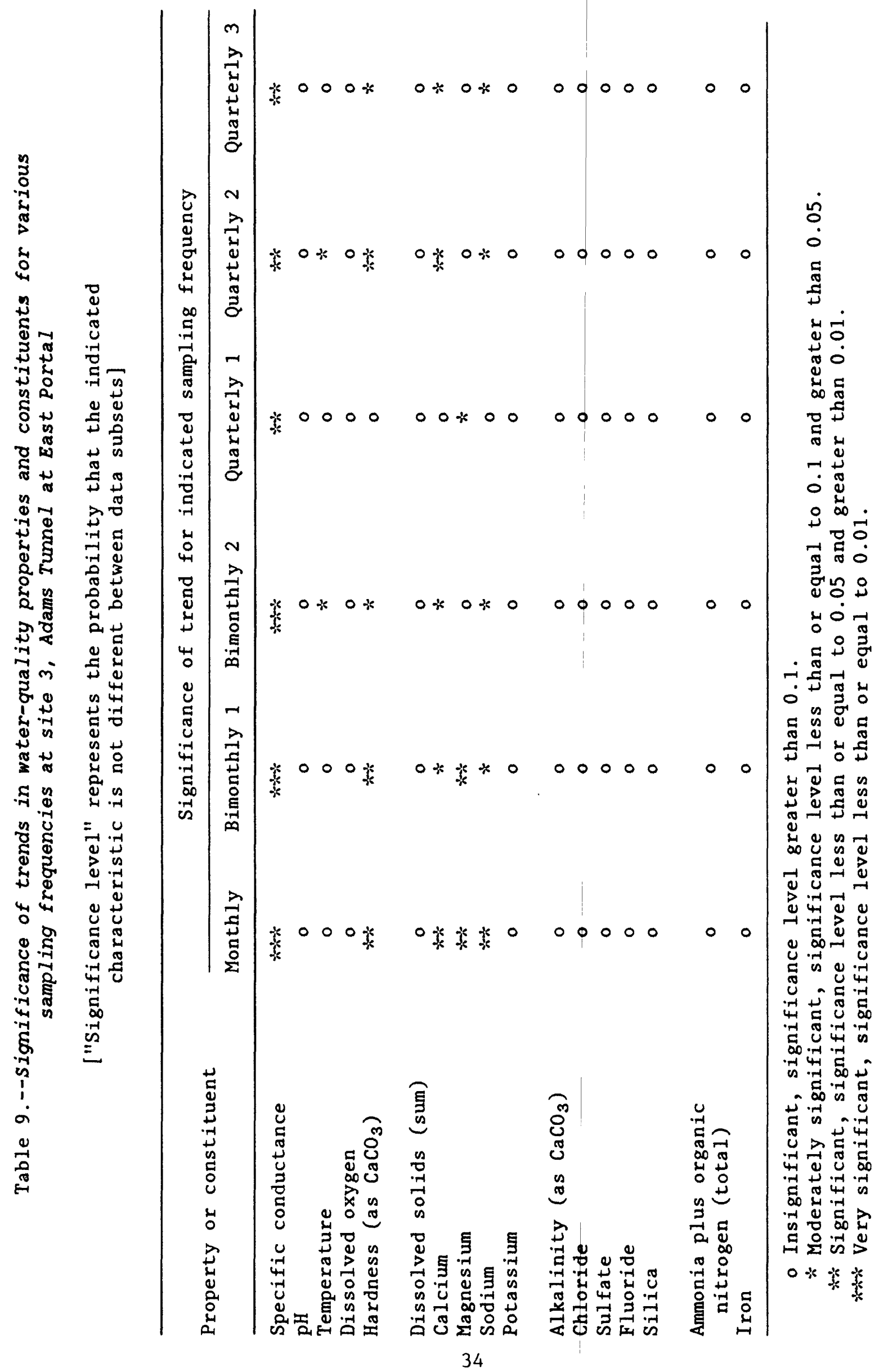


subsets, only the trend in specific conductance is preserved consistently. Decreasing sampling to a bimonthly frequency would not cause a substantial loss of information, but decreasing to a quarterly frequency would. Sampling based on the Bimonthly 1 schedule (odd-numbered months) may be more representative than sampling based on the Bimonthly 2 schedule because more trends were preserved in the Bimonthly 1 data subset and no extraneous trends were identified.

The only significant differences identified at site 7, Boulder Creek, were between the bimonthly median values of fecal coliform concentration and among the quarterly spread in $\mathrm{pH}$ (table 10). In both instances, the significance level was just barely in the significant range, and neither difference seemed to be consequential in the box plots (fig. 9). None of the box plots indicated much difference among any of the tested sampling frequencies.

However, comparison of trend analysis results leads to a different conclusion. Five significant or very significant trends were identified in the monthly data, but in two of the quarterly data subsets only two of these trends were preserved (table 11). At least three of these trends are identified in each of the bimonthly data subsets. The trend in fecal coliform is not significant in any of the data subsets. At this site, sampling frequency could be decreased to bimonthly, but decreasing to a quarterly frequency could result in a substantial loss of information. If fecal-coliform data are of particular interest, monthly analyses may be necessary.

At site 9, South Platte River near Weldona, no significant differences were identified between the bimonthly subsets, but several differences in median and spread among the quarterly subsets were determined to be significant (table 12). None of these difference are very apparent in the box plots (fig. 10), which indicate that all the bimonthly and quarterly data distributions are nearly identical to the monthly data distribution. This site had the largest number of samples of any streamflow site in the study area. As sample size increases, smaller differences may be determined to be significant; therefore, the results in table 12 may be overly restrictive. Based on comparison of the box plots in figure 10, including those for major ions, nutrients, and trace metals, little loss of information would occur if the sampling frequency was decreased to quarterly. This conclusion is supported by the comparison of trend analysis results (table 13). Sixteen significant trends were identified in the monthly data, and all but two of these are preserved in every quarterly data subset.

At site 10, Colorado River near Radium, significant differences were identified between bimonthly data subsets for median manganese concentration and for spread in sulfate concentration (table 14). The bimonthly distributions of manganese also seem different in box plots (fig. 11); however, the magnitude of the differences may be exaggerated by the reporting interval for manganese data. Because concentrations of manganese are reported to the nearest $10 \mu \mathrm{g} / \mathrm{L}$, the box plots for manganese in figure 11 are based on only 4 possible values $(10,20,30$, or $40 \mu \mathrm{g} / \mathrm{L})$ measured in the 49 samples from the site. In one bimonthly subset, at least half of these values were either 20 or 30 , and in the other subset, at least half were either 10 or 20 . These distributions are different, but the rounding of reported values may make the difference seem more extreme than it actually is. In contrast, the significant difference in bimonthly sulfate spread seemed to be minor in the box plots. The bimonthly distributions are different from each other, but neither 
Table 10.--Significance of differences in water-quality properties and constituents among selected bimonthly and quarterly sampling schedules at site 7, Boulder Creek at mouth ${ }^{1}$

["Significance level" represents the probability that the indicated characteristic is not different between data subsets]

\begin{tabular}{|c|c|c|c|c|c|}
\hline \multirow{3}{*}{$\begin{array}{l}\text { Property } \\
\text { or } \\
\text { constituent }\end{array}$} & \multirow{3}{*}{$\begin{array}{l}\text { Number } \\
\text { of } \\
\text { samples }\end{array}$} & \multicolumn{4}{|c|}{ Significance level } \\
\hline & & \multicolumn{2}{|c|}{ Bimonthly } & \multicolumn{2}{|c|}{ Quarterly } \\
\hline & & Median & Spread & Median & Spread \\
\hline Streamflow & 95 & 0.18 & 0.80 & 0.99 & 0.90 \\
\hline $\mathrm{pH}$ & 93 & 0.29 & 0.39 & 0.83 & $0.09 *$ \\
\hline Temperature & 94 & 0.24 & 0.81 & 0.94 & 0.78 \\
\hline Dissolved oxygen & 89 & 0.39 & 0.95 & 0.72 & 0.38 \\
\hline Hardness (as $\left.\mathrm{CaCO}_{3}\right)$ & 95 & 0.39 & 0.43 & 0.96 & 0.87 \\
\hline Dissolved solids & 92 & 0.30 & 0.51 & 0.98 & 0.81 \\
\hline Chloride & 95 & 0.81 & 0.57 & 0.81 & 0.83 \\
\hline Sulfate & 94 & 0.26 & 0.58 & 0.88 & 0.84 \\
\hline $\begin{array}{l}\text { Nitrite plus nitrate } \\
\text { as nitrogen }\end{array}$ & 92 & 0.64 & 0.23 & 0.97 & 0.47 \\
\hline Phosphorus & 92 & 0.88 & 0.21 & 0.67 & 0.87 \\
\hline Iron & 95 & 0.59 & 0.33 & 0.97 & 0.45 \\
\hline Manganese & 95 & 0.92 & 0.31 & 0.90 & 0.40 \\
\hline Fecal coliform & 73 & $0.10 *$ & 0.31 & 0.91 & 0.29 \\
\hline
\end{tabular}

1 See table 1 for site description and figure 1 for site location.

* Moderately significant, significance level less than or equal to 0.1 and greater than 0.05 .

** Significant, significance level less than or equal to 0.05 and greater than 0.01 .

**: Very significant, significance level less than or equal to 0.01 .

is much different from the monthly distribution. Substantial differences among the quarterly data subsets are shown in the box plots of dissolvedsolids and sulfate concentrations. In addition, the box plots of total phosphorus and nickel concentrations indicate that quarterly data distributions were different from the monthly data distributions. The plots in figure 11 show that the bimonthly data distributions are similar to the monthly distribution for all properties and constituents except manganese. The bimonthly distributions of streamflow also are similar to the monthly distribution, but the quarterly distributions are not. If sampling was decreased to a quarterly frequency, the sampled flow regime would be dependent on the months selected for sample collection. Data were insufficient for comparison of trend results for quarterly data subsets, and the results for bimonthly data subsets were inconclusive (table 15). 

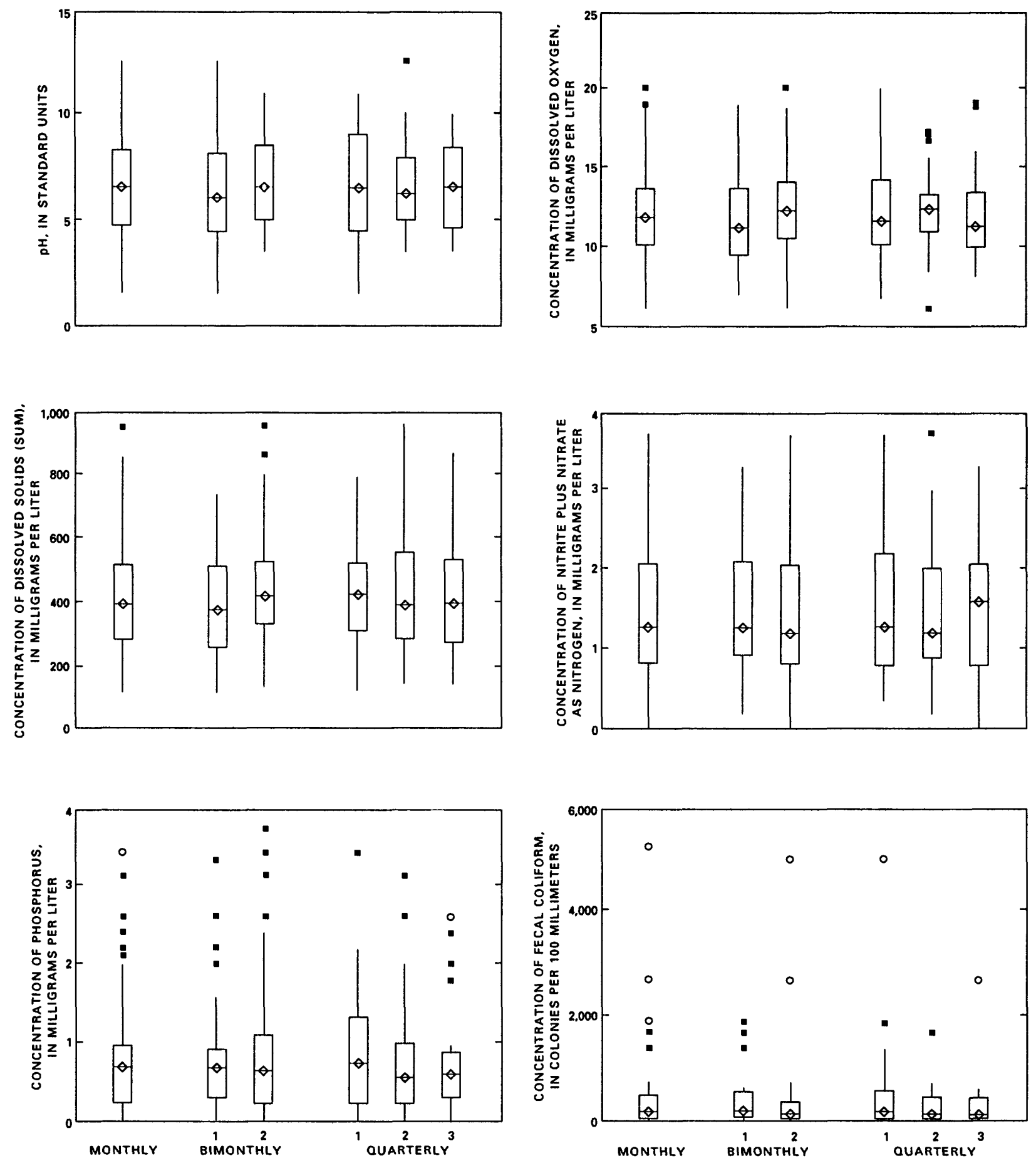

Figure 9.--Seleted data distributions for various sampling frequencies at site 7 , Boulder Creek at mouth. 

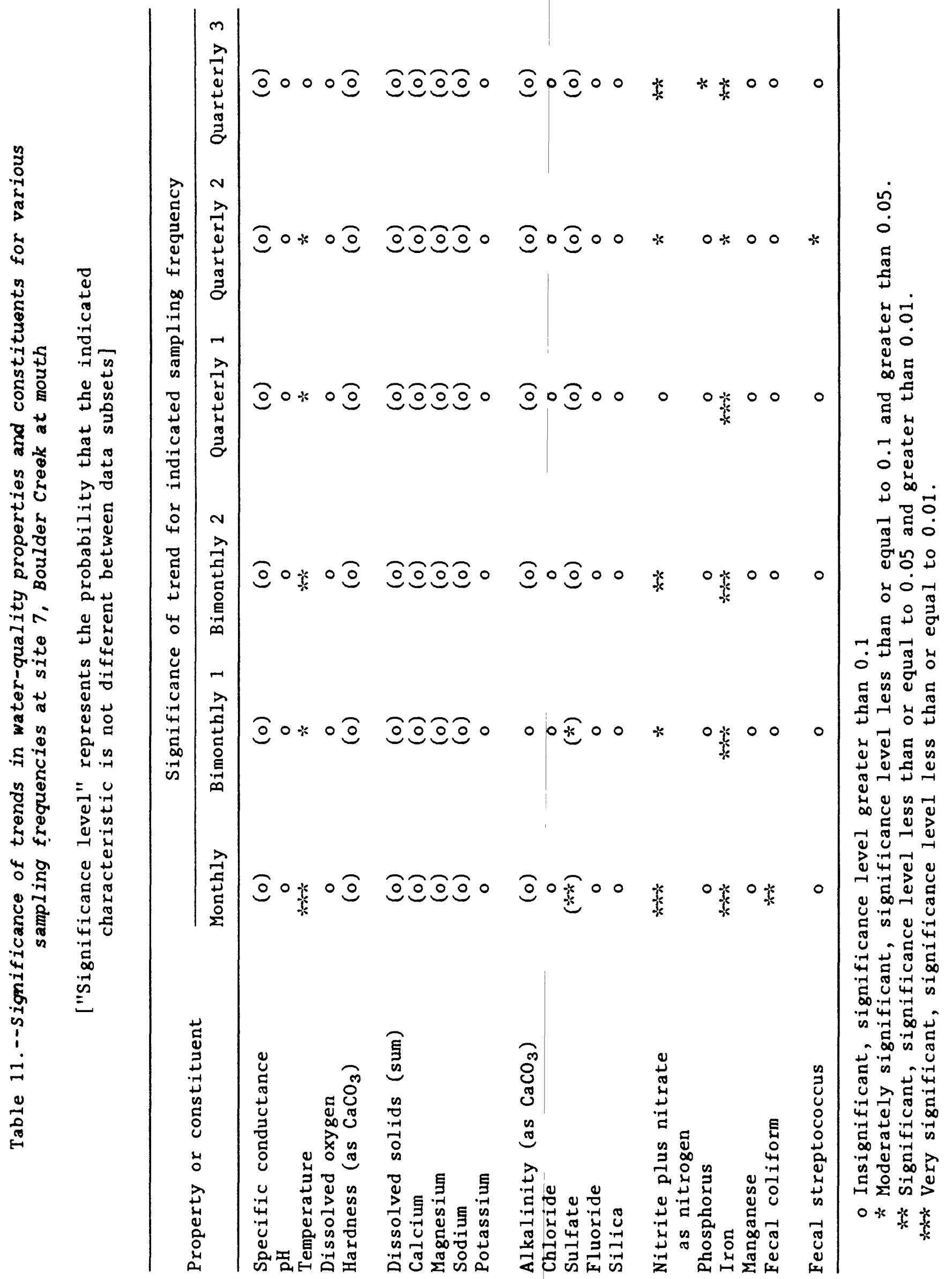
One bimonthly data subset preserved only two of the six significant trends identified in the monthly data, and included three extraneous trends. In the second bimonthly data subset, four of the six trends were preserved, and no extraneous trends were identified. In general, there is little evidence that a decrease to bimonthly sampling would affect the data distributions, and information concerning trends may be preserved if the proper sampling schedule is selected. A decrease to quarterly sampling probably would result in a substantial loss of information.

Table 12.--Significance of differences in water-quality properties and constituents among selected bimonthly and quarterly sampling schedules at site 9, South Platte River near Weldona ${ }^{1}$

["Significance level" represents the probability that the indicated characteristic is not different between data subsets]

\begin{tabular}{|c|c|c|c|c|c|}
\hline \multirow{3}{*}{$\begin{array}{l}\text { Property } \\
\text { or } \\
\text { constituent }\end{array}$} & \multirow{3}{*}{$\begin{array}{l}\text { Number } \\
\text { of } \\
\text { samples }\end{array}$} & \multicolumn{4}{|c|}{ Significance level } \\
\hline & & \multicolumn{2}{|c|}{ Bimonthly } & \multicolumn{2}{|c|}{ Quarterly } \\
\hline & & Median & Spread & Median & Spread \\
\hline Streamflow & 203 & 0.90 & 0.87 & 0.96 & 0.38 \\
\hline $\mathrm{pH}$ & 199 & 0.49 & 0.19 & $0.10 \%$ & 0.47 \\
\hline Temperature & 203 & 0.97 & 0.90 & $>0.99$ & 0.56 \\
\hline Dissolved oxygen & 191 & 0.61 & 0.30 & 0.91 & $0.03 * \cdots$ \\
\hline Hardness (as $\left.\mathrm{CaCO}_{3}\right)$ & 203 & 0.99 & 0.77 & 0.85 & 0.19 \\
\hline Dissolved solids & 203 & 0.70 & 0.84 & 0.50 & $0.09 *$ \\
\hline Chloride & 203 & 0.67 & 0.45 & 0.21 & $0.07 *$ \\
\hline Sulfate & 203 & 0.81 & 0.74 & 0.45 & $0.09 *$ \\
\hline $\begin{array}{l}\text { Nitrite plus nitrate } \\
\text { as nitrogen }\end{array}$ & 200 & 0.66 & 0.90 & 0.41 & 0.13 \\
\hline Phosphorus & 107 & 0.97 & 0.77 & 0.97 & 0.30 \\
\hline Iron & 202 & 0.45 & 0.59 & 0.39 & 0.37 \\
\hline Manganese & 200 & 0.23 & 0.69 & 0.14 & 0.22 \\
\hline
\end{tabular}

1 See table 1 for site description and figure 1 for site location.

* Moderately significant, significance level less than or equal to 0.1 and greater than 0.05 .

$*$ Significant, significance level less than or equal to 0.05 and greater than 0.01 .

***: Very significant, significance level less than or equal to 0.01 . 

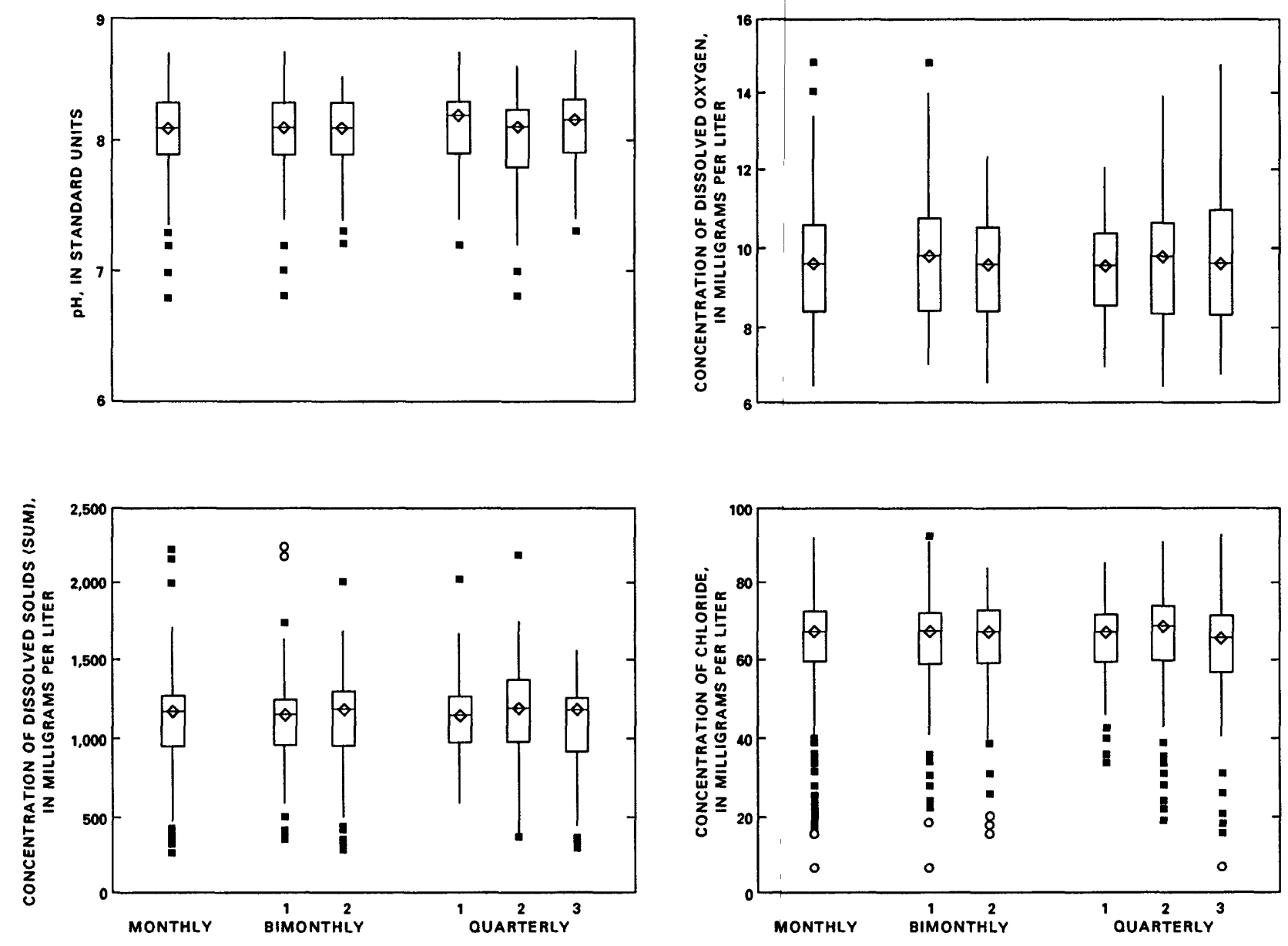

Figure 10.--Selected data distributions for various sampling frequencies at site 9, South Platte River near Weldona (dashes indicate detection limits). 

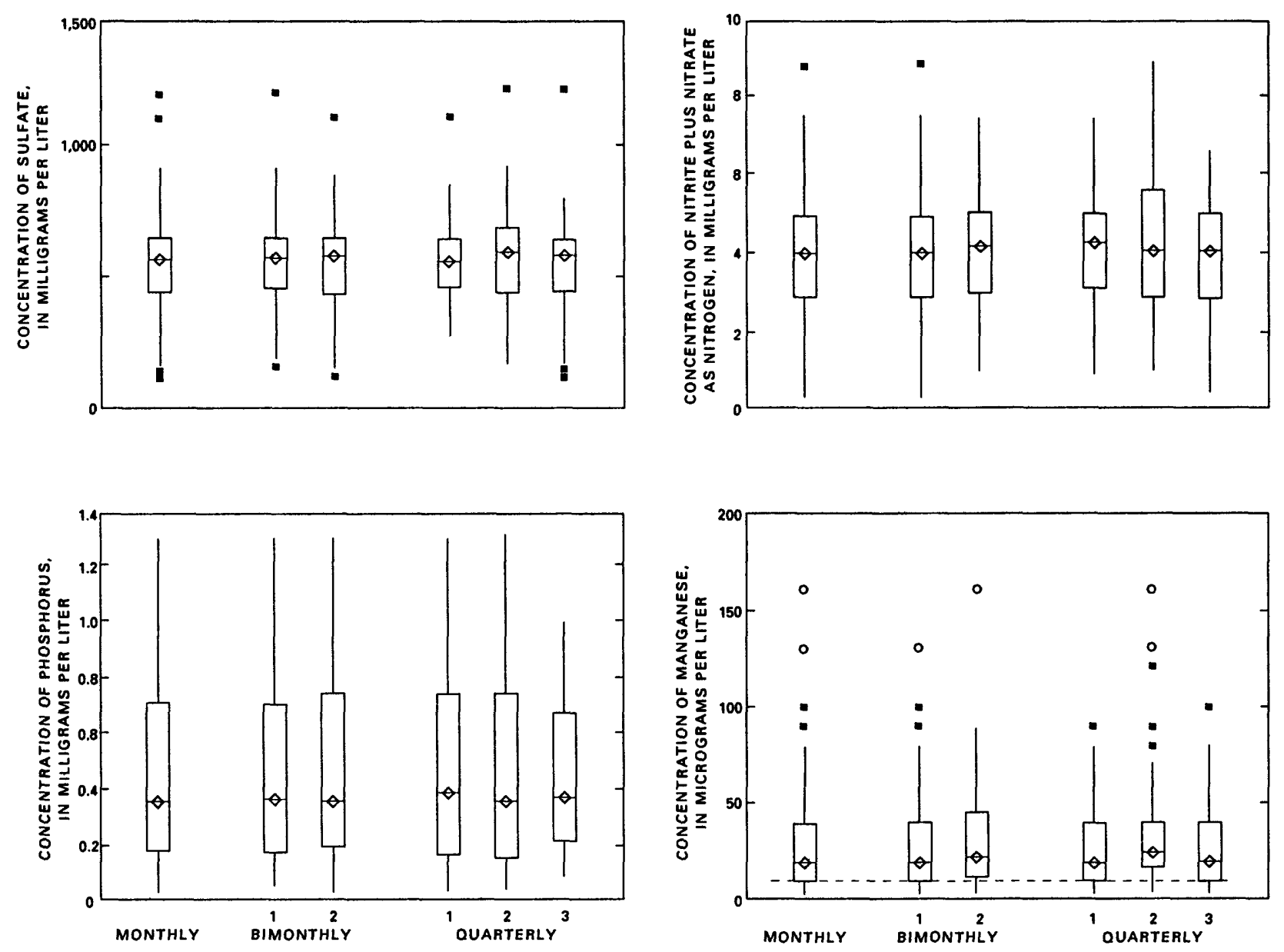

Figure 10.--Selected data distributions for various sampling frequencies at site 9, South Platte River near Weldona (dashes indicate detection limits)--Continued. 

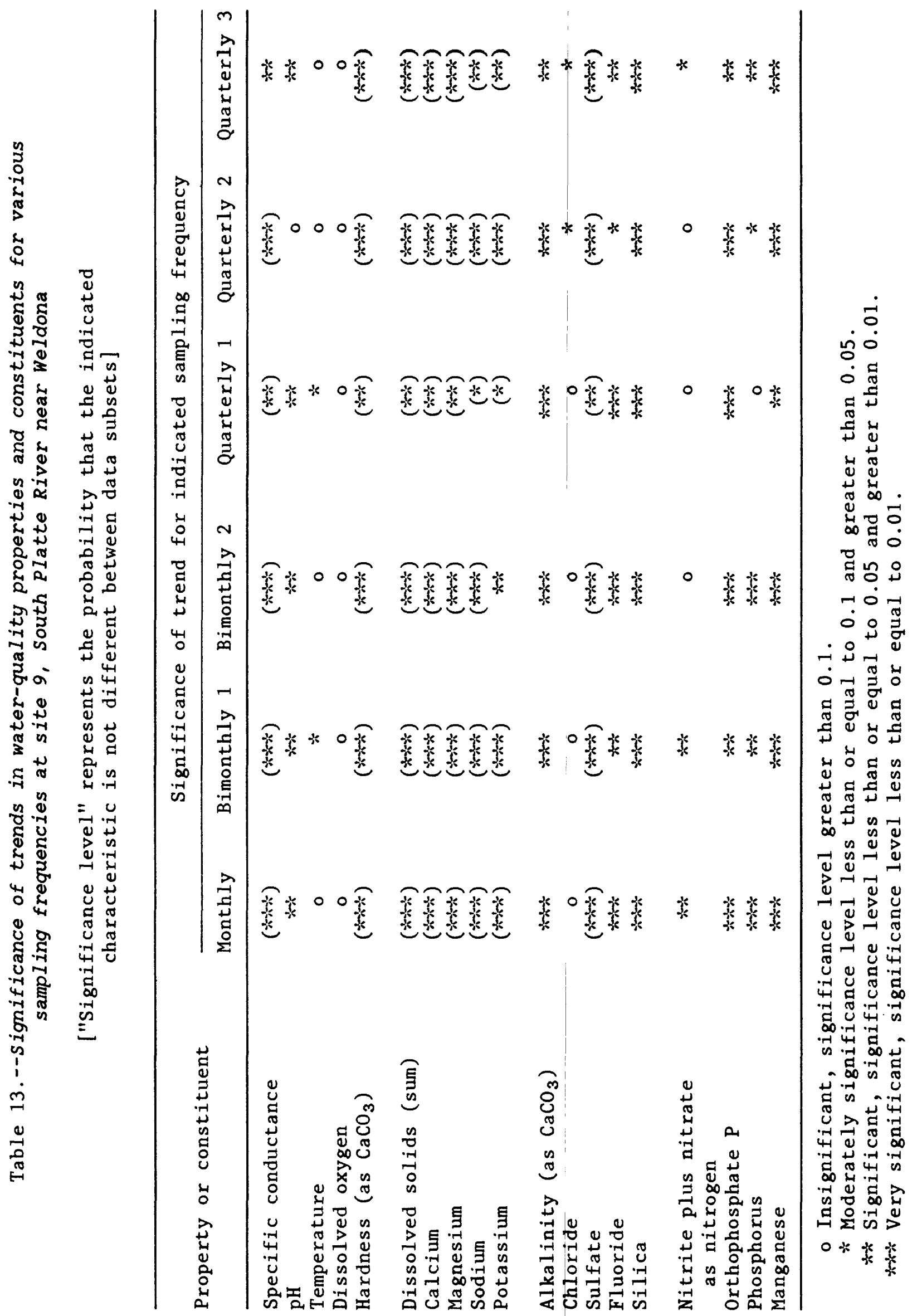
Table 14.--Significance of differences in water-quality properties and constituents among selected bimonthly and quarterly sampling schedules at site 10, Colorado River near Radium ${ }^{1}$

["Significance level" represents the probability that the indicated characteristic is not different between data subsets]

\begin{tabular}{|c|c|c|c|c|c|}
\hline \multirow{3}{*}{$\begin{array}{l}\text { Property } \\
\text { or } \\
\text { constituent }\end{array}$} & \multirow{3}{*}{$\begin{array}{l}\text { Number } \\
\text { of } \\
\text { samples }\end{array}$} & \multicolumn{4}{|c|}{ Significance level } \\
\hline & & \multicolumn{2}{|c|}{ Bimonthly } & \multicolumn{2}{|c|}{ Quarterly } \\
\hline & & Median & Spread & Median & Spread \\
\hline Streamflow & 49 & 0.52 & 0.45 & 0.95 & 0.89 \\
\hline $\mathrm{pH}$ & 49 & 0.36 & 0.93 & 0.46 & 0.97 \\
\hline Temperature & 49 & 0.56 & 0.16 & 0.87 & 0.96 \\
\hline Dissolved oxygen & 49 & 0.57 & 0.21 & 0.62 & 0.93 \\
\hline Hardness (as $\left.\mathrm{CaCO}_{3}\right)$ & 45 & 0.64 & 0.54 & 0.49 & 0.14 \\
\hline Dissolved solids (residue) & 49 & 0.49 & 0.23 & $0.02 * *$ & $0.08 *$ \\
\hline Chloride & 45 & 0.19 & 0.23 & 0.82 & 0.35 \\
\hline Sulfate & 49 & 0.57 & $0.05 * *$ & $0.02 * *$ & 0.58 \\
\hline $\begin{array}{l}\text { Nitrite plus nitrate } \\
\quad \text { as nitrogen }\end{array}$ & 49 & 0.42 & 0.26 & 0.17 & 0.46 \\
\hline Phosphorus (total) & 48 & 0.71 & 0.85 & 0.85 & 0.56 \\
\hline Iron & 49 & 0.30 & 0.43 & 0.88 & 0.49 \\
\hline Manganese & 49 & $0.03 * *$ & 0.80 & $0.05 * *$ & 0.24 \\
\hline Manganese (total recoverable) & 48 & 0.87 & 0.86 & 0.67 & 0.48 \\
\hline Nickel & 48 & 0.32 & 0.61 & 0.60 & 0.34 \\
\hline Fecal coliform & 42 & 0.85 & 0.98 & 0.92 & 0.54 \\
\hline
\end{tabular}

1 See table 1 for site description and figure 1 for site location.

* Moderately significant, significance level less than or equal to 0.1 and greater than 0.05 .

$*$ Significant, significance level less than or equal to 0.05 and greater than 0.01 .

***: Very significant, significance level less than or equal to 0.01 . 

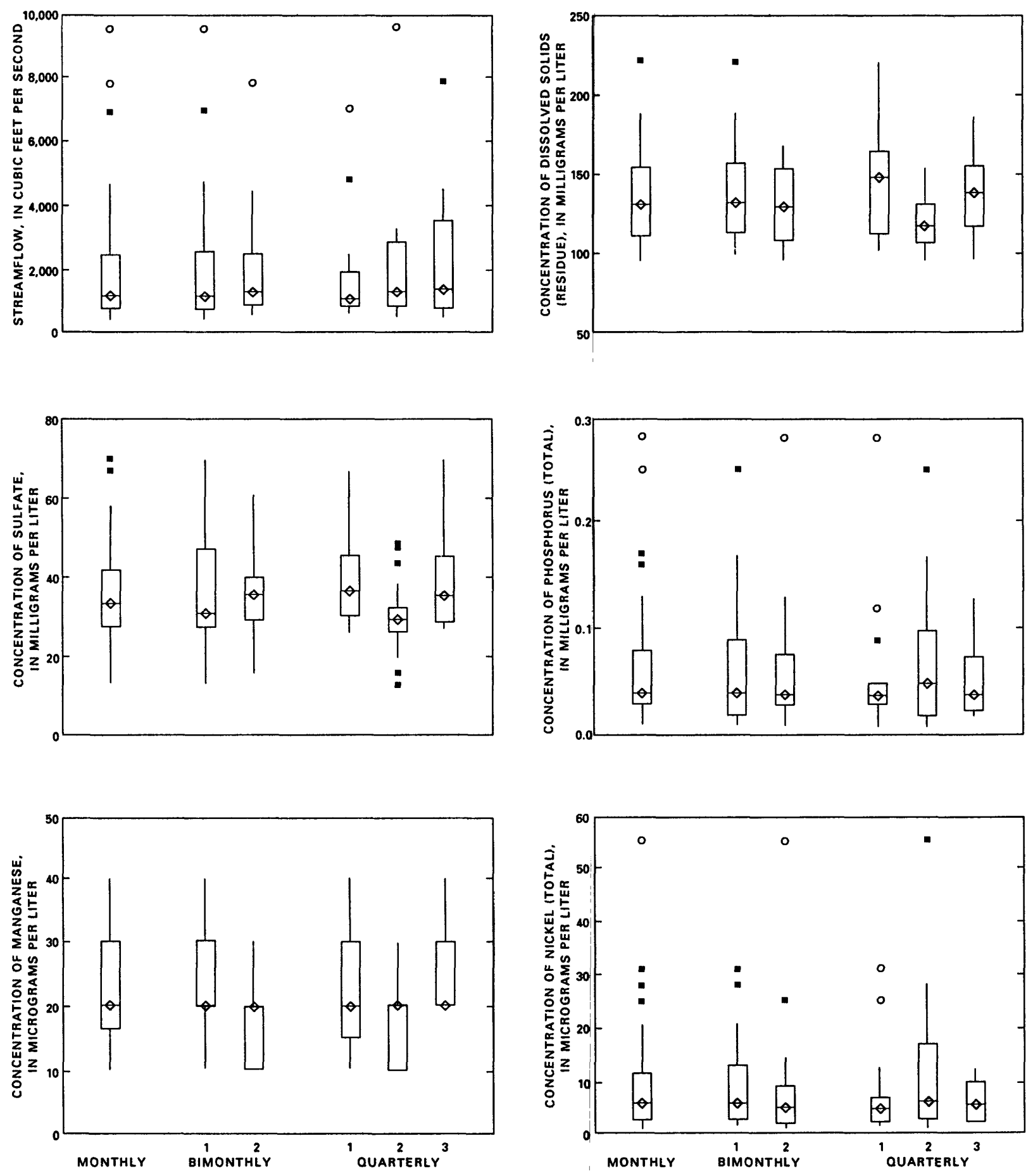

Figure 11.--Selected data distributions for various sampling frequencies at site 10 , Colorado River near Radium. 


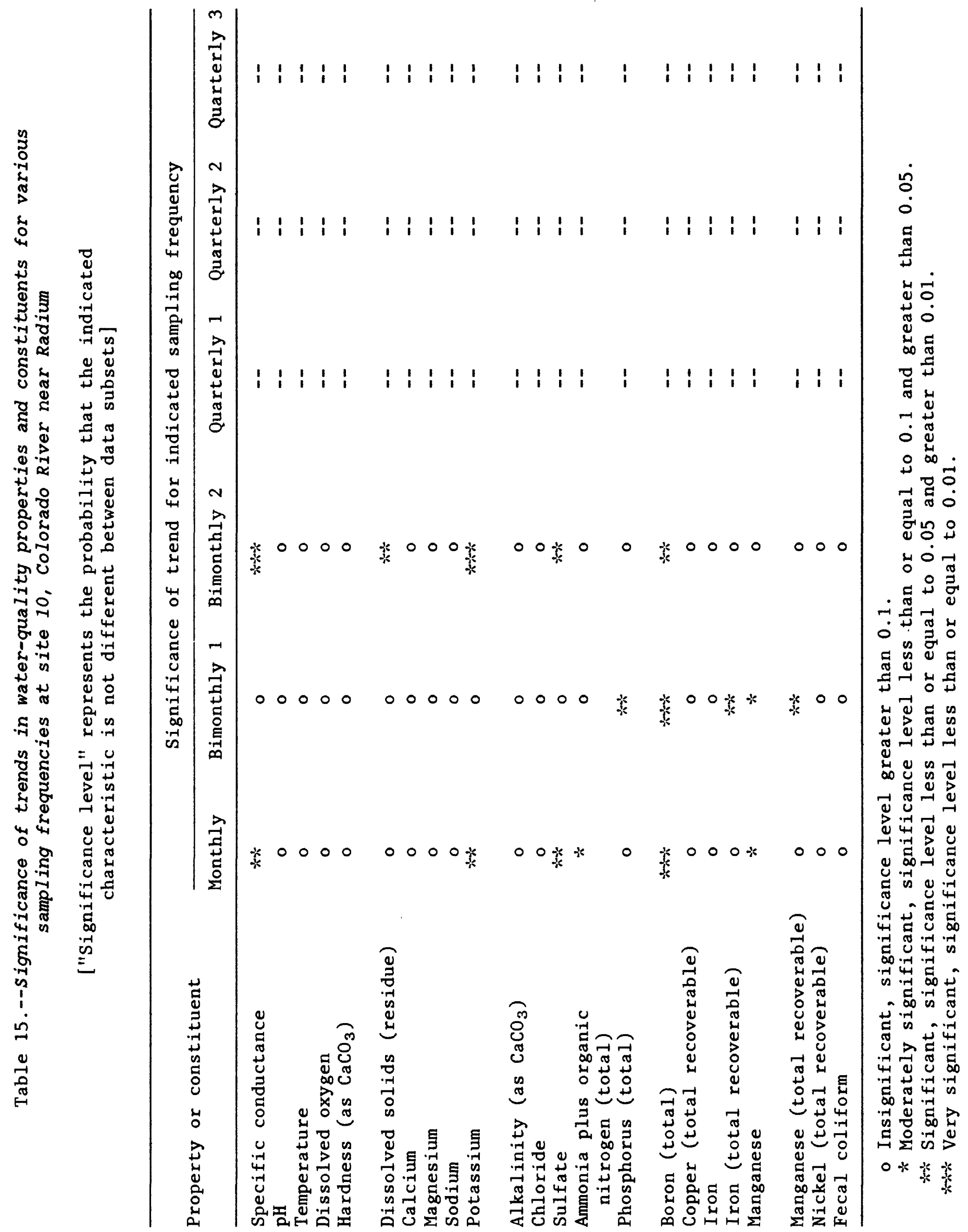




\section{Sampling Location at Reservoir Sites}

At the reservoir sites (1, Lake Granby; 5, Horsetooth Reservoir; and 6, Carter Lake), there were insufficient data to analyze sampling frequency. However, the same techniques used for analysis of sampling frequency at the streamflow sites were used to test the necessity of more than one sampling location or depth in a reservoir. From 1983 to 1987, samples were collected three times per year at three locations each in Horsetooth Reservoir (site 5) and Carter Lake (site 6). Each time, samples were collected from near the surface and from a few feet above the bottom. Significant differences in median values among the three sampling locations and between the two sampling depths were identified by using analysis of variance or $t$ tests on ranks of the data (Conover and Iman, 1981). Significant differences in data spread were identified by using the squared-ranks test (Conover, 1980). Side-by-side box plots were used to compare the distributions of data from surface and bottom samples collected at the north, center, and south stations at each reservoir. No analyses were made of data from Lake Granby (site 1) because samples were collected at only one location during the period of record through 1987.

Results of the analysis of sampling location and depth for Horsetooth Reservoir (site 5) are presented in table 16 and figure 12. No significant differences were identified among sample locations for any property or constituent in surface samples. Moderately significant or significant differences in median concentrations of lead and manganese occurred in bottom samples. These differences were very obvious in the box plots. In addition, the box plots of total recoverable iron concentration indicated differences similar to those of manganese concentration. For iron and manganese, concentrations were higher at the south end of the reservoir near the main inlet than at the north end near the two main outlets. These trace metals may settle to the bottom soon after water enters the reservoir and, therefore, may accumulate near the south sampling station. In general, the other properties and constituents tended to vary more with depth than with location. For example, the median values and interquartile ranges of temperature at the surface were nearly identical at all sampling stations. Median values of temperature at the bottom also were nearly identical, but much smaller than the median values of surface temperatures. The upper quartile of bottom temperatures was smaller than the lower quartile of surface temperatures. Box plots of specific conductance, $\mathrm{pH}$, and nitrite plus nitrate concentration also showed more variation between the surface and bottom than among sampling locations (fig. 12). Based on these results, the only change that could be made to the 1987 sampling program without losing information would be to discontinue sampling at the center station. Surface and bottom sampling are necessary to define variations with depth. Samples from the north and south stations are necessary to determine the overall range of trace-metal concentrations. (Lead concentrations were lowest at the center station, but most historical values were less than the current (1988) detection limit of $5 \mu \mathrm{g} / \mathrm{L}$. ) 


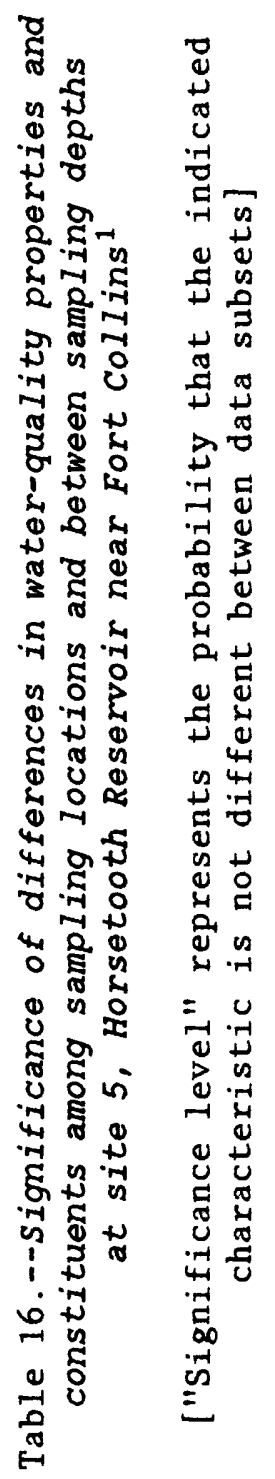

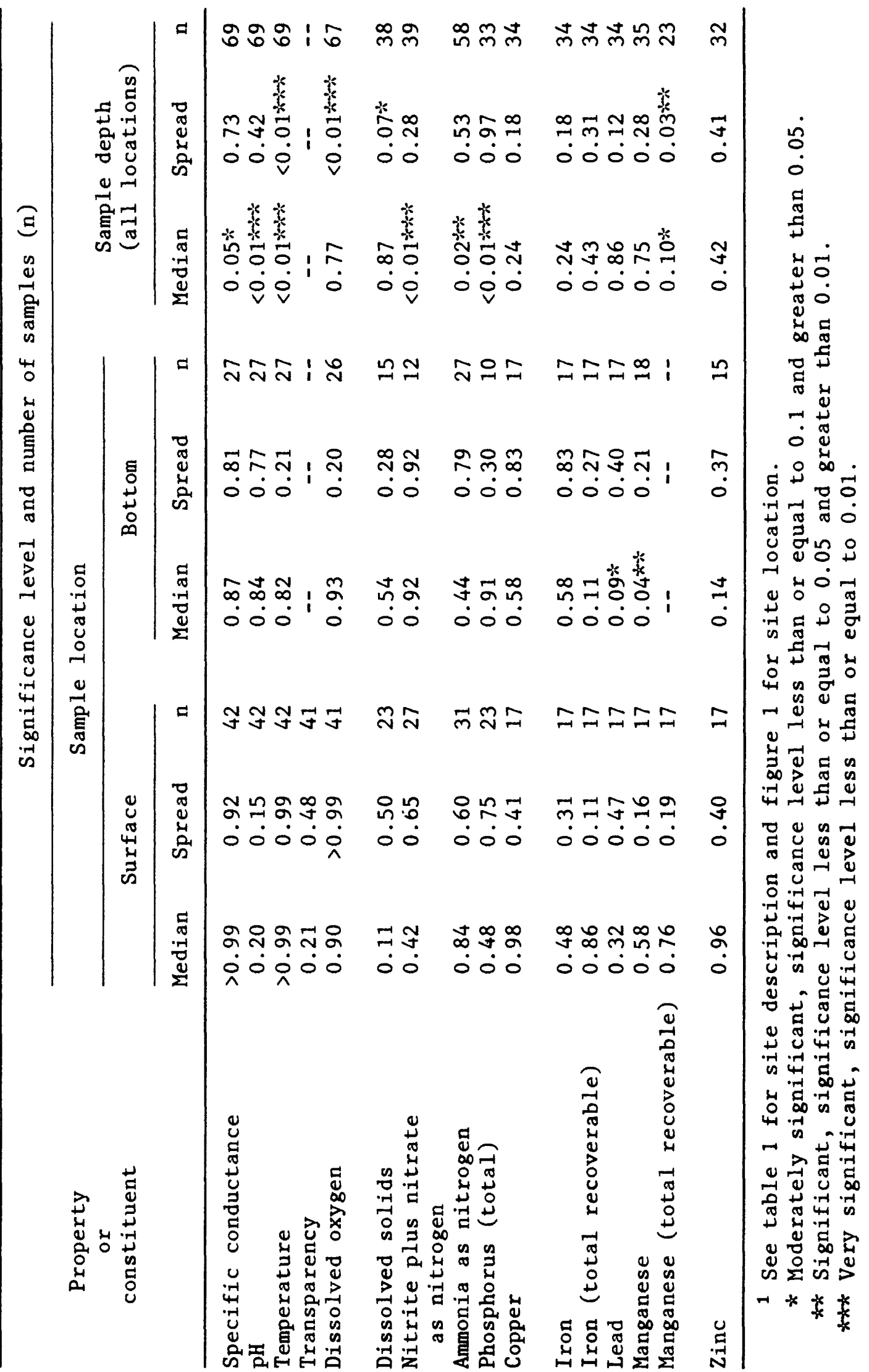



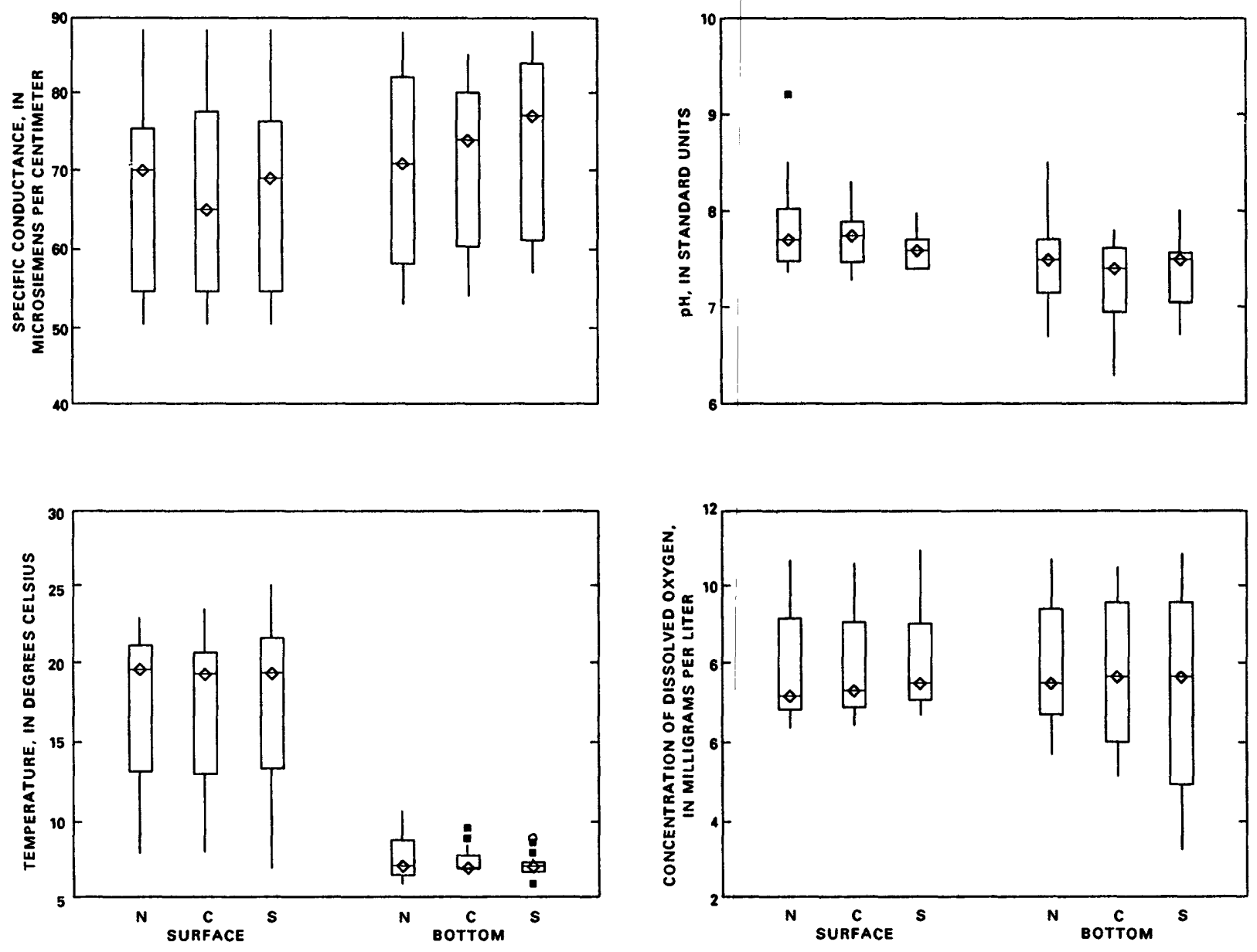

Figure 12.--Selected data distributions for surface and bottom samples from the north (N), center (C), and south (S) sampling stations at site 5, Horsetooth Reservoir near Fort Collins (dashed indicate detection limits). 

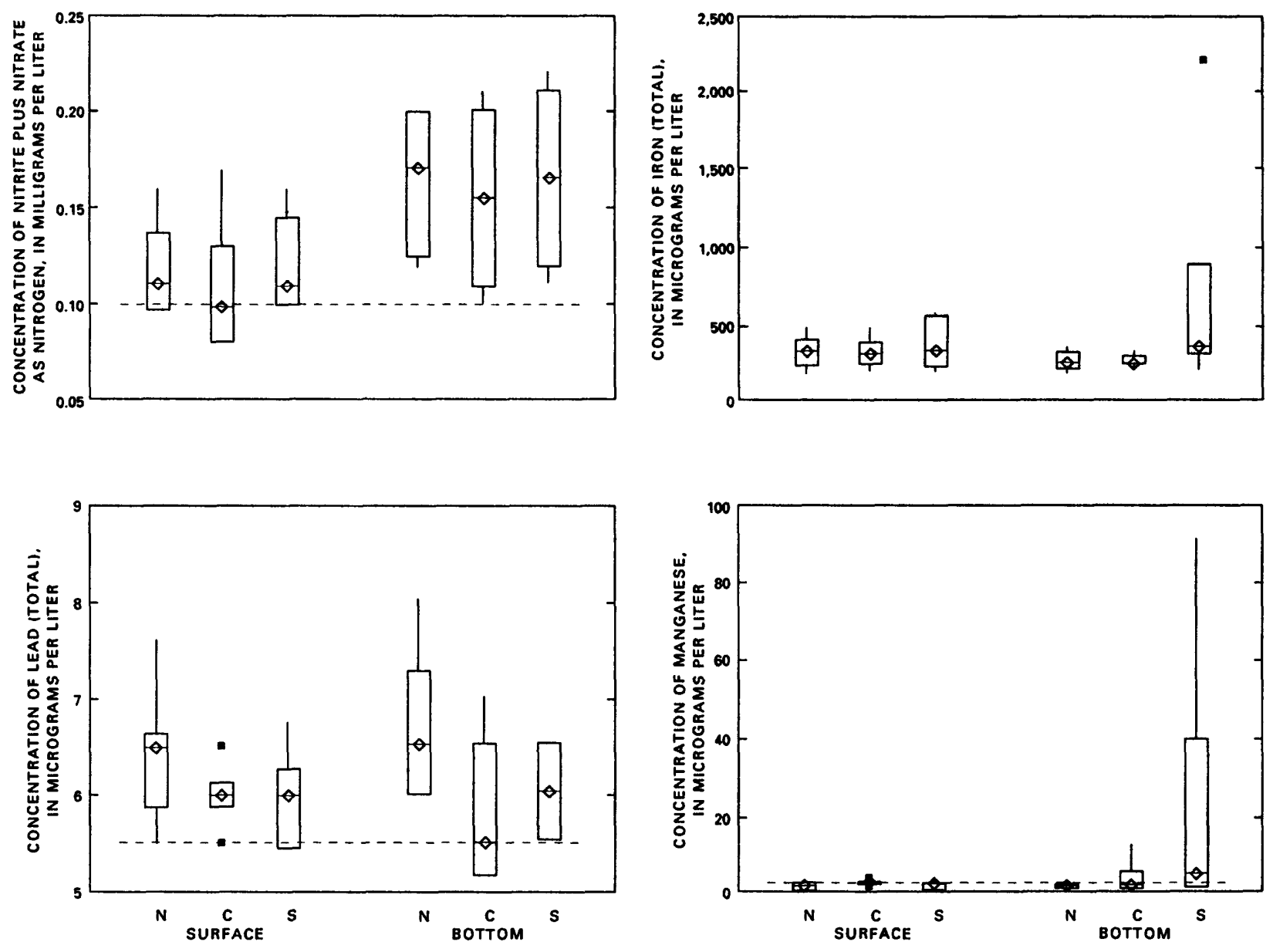

Figure 12.--Selected data distributions for surface and bottom samples from the north (N), center (C), and south (S) sampling stations at site 5, Horsetooth Reservoir near Fort Collins (dashes indicate detection limits)--Continued. 
At site 6, Carter Lake, the only significant difference identified among sampling locations was for median values of dissolved-solids concentration as residue on evaporation (table 17 ). This difference also was obvious in the box plots (fig. 13), but the actual differences in concentration were very small. Furthermore, no differences among sampling locations were identified for specific conductance, which is a measure of the dissolved ionic concentration. Among surface samples, specific-conductance data are nearly twice as numerous and probably provide a better indication of dissolved-solids concentration than residue on evaporation. The other box plots in figure 13 display little difference among sampling locations, but significant differences are indicated between sampling depths. Surface and bottom sampling are necessary, but probably only at one location in the reservoir (the south station, because it has the longest period of record).

\section{Laboratory Analyses}

No quantitative analyses were made to test the existing schedules for laboratory analyses of samples at each site. However, a list of proposed onsite measurements and laboratory analyses was prepared based on the following qualitative criteria:

1. Consistency with past data collection at the study sites and with other ongoing water-quality data-collection programs.

2. Consistency among the study sites.

3. Determination of compliance with water-quality standards.

4. Completeness of analyses for certain groups of constituents, primarily major dissolved species and nutrients.

The proposed measurements and analyses are listed in table 18. The list is divided into several groups, including onsite measurements, laboratory measurements, major dissolved constituents, nutrients, trace metals, nonmetallic trace constituents, organic pesticides, bacteria, and chlorophyll. Properties and constituents that are regulated by State water-quality standards are identified, and special scheduling concerns are presented. Use of this analytic schedule at all sites could provide a more uniform data set for the study area and facilitate comparisons among sites. Common trends could be identified easily.

Onsite measurements are made at the time of sampling. State standards exist for $\mathrm{pH}$ and for dissolved oxygen concentration at every site in the study area, (although for canal and tunnel sites standards apply to reservoir source water). Streamflow measurement is necessary for computation of mass discharge or load of water-quality constituents. Specific conductance is related to dissolved-solids concentration and is included as a quality-control measure on that analysis. Among other uses, temperature is required in the computation of un-ionized ammonia and in other geochemical calculations. Transparency is useful in determining the trophic status of a reservoir. Laboratory measurement of specific conductance and $\mathrm{pH}$ provide a quality-control check on the onsite measurements. 


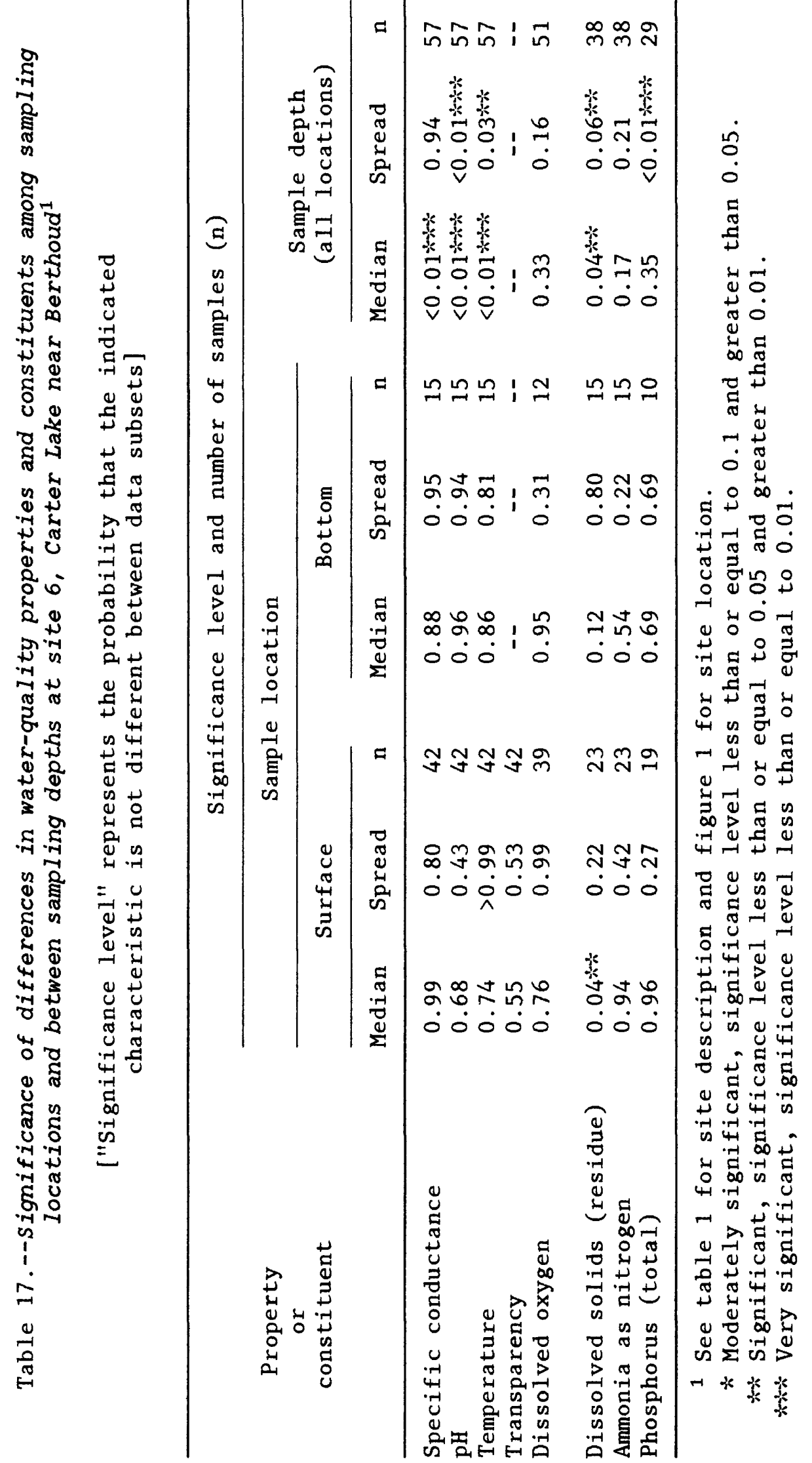



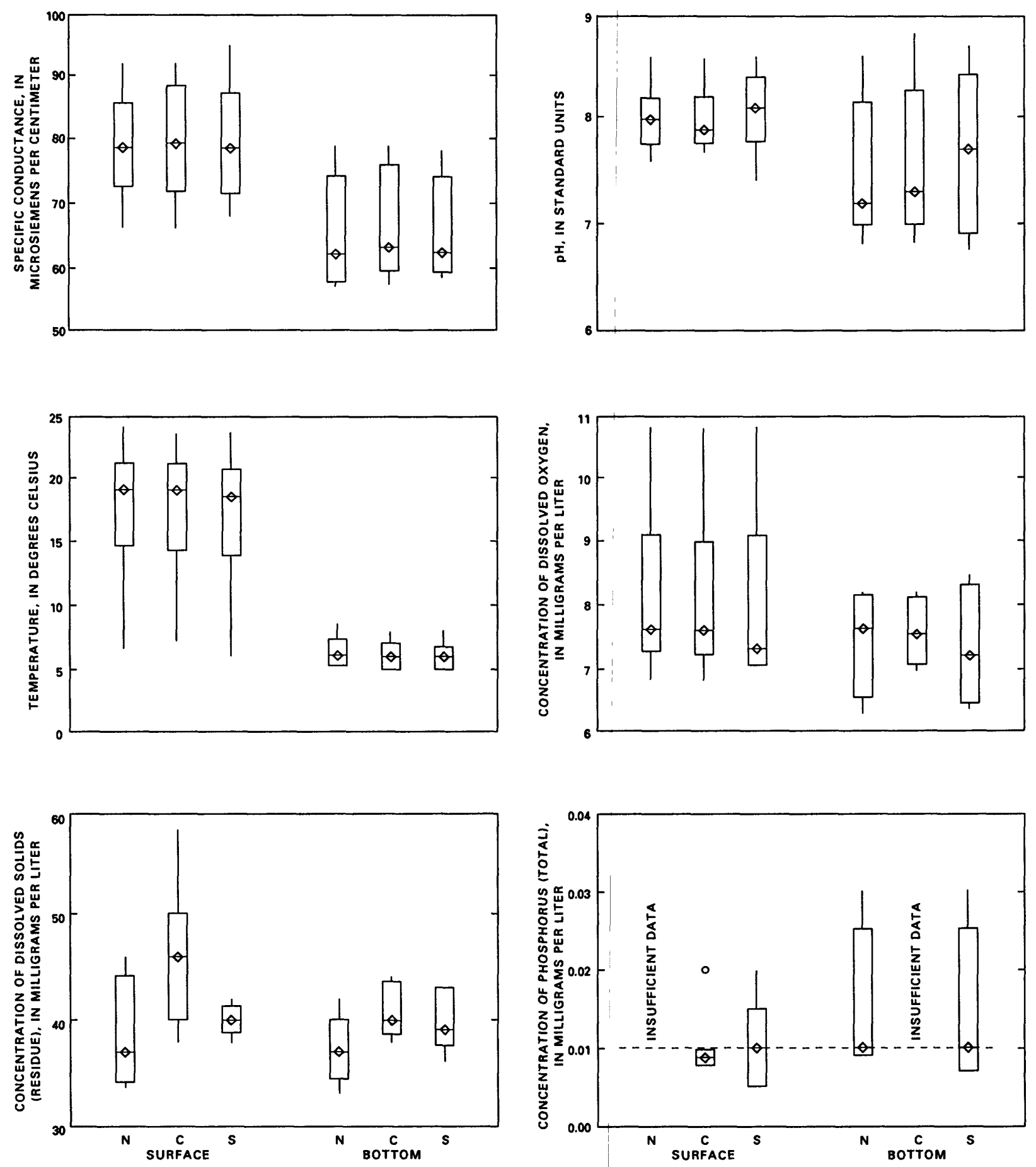

Figure 13.--Selected data distributions for surface and bottom samples from the north (N), center (C), and south (S) sampling stations at site 6, Carter Lake near Berthoud (dashes indicate detection limits). 
Table 18.--proposed schodule for onsite mesurements and laboratory analyses for samples from all study sites 1

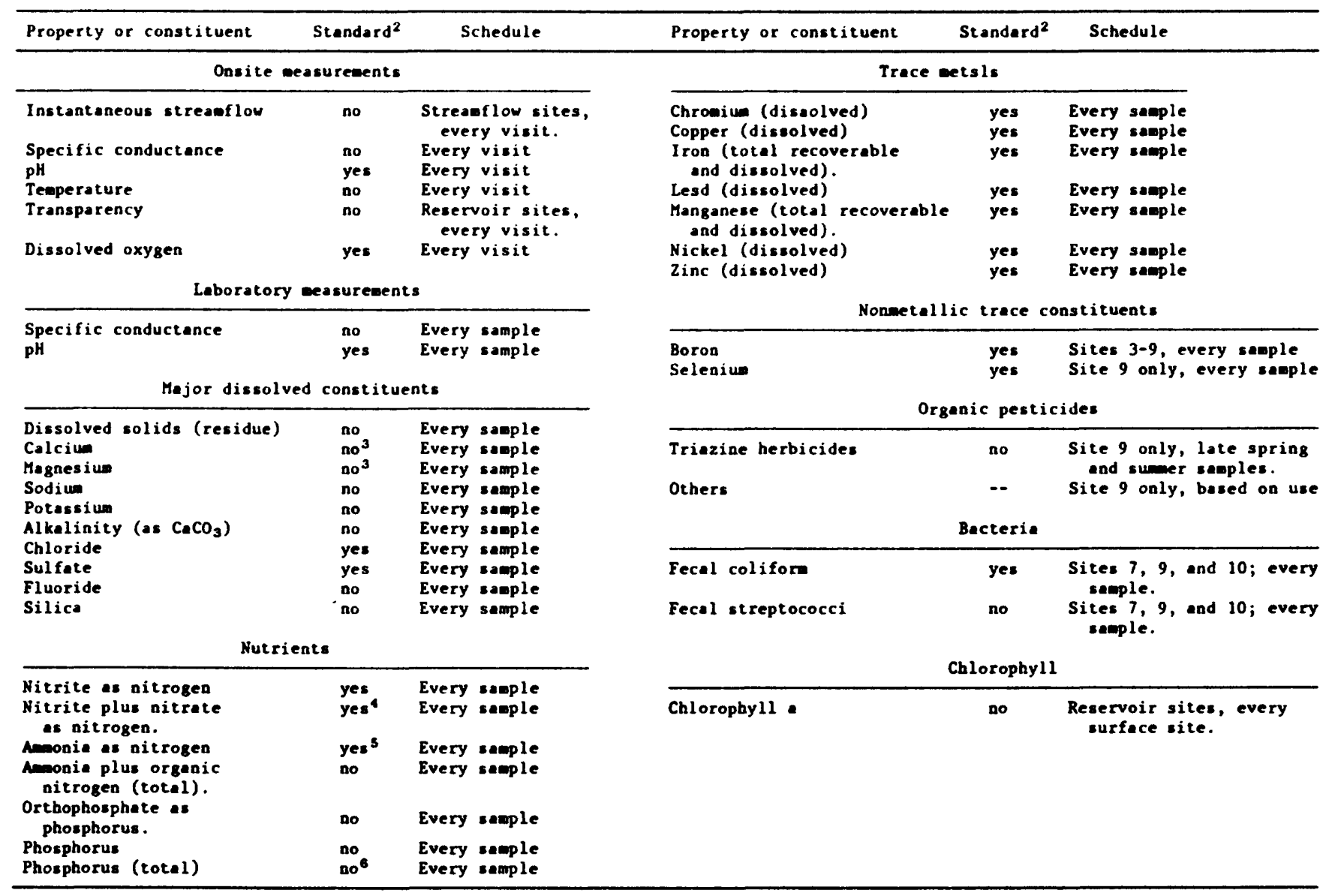

'See table 1 for site description and figure 1 for site location.

2 Colorado Depertment of Health (1986, 1987).

3o stenderd, but required for computing herdness for trece-eetel standards.

"Standerd is for aitrete only.

Standard is for un-ionized smonia.

Wo stendard, but maximu concentration goel.

Dissolved-solids and major dissolved-constituent concentrations provide an indication of the suitability of water for irrigation. State standards exist only for chloride and sulfate, but calcium and magnesium concentrations are necessary for computing hardness, which is required in the determination of many trace-metal standards. The major dissolved constituents listed in table 33 are included in the calculation of dissolved-solids concentration as sum of constituents. This sum can be compared, as a quality-control check, to the analytical value of dissolved-solids concentration determined by residue on evaporation. 
There is a State standard for nitrite at all sites. Nitrate, for which there is a standard at many sites, can be computed from the nitrite and nitrite plus nitrate analyses. Un-ionized ammonia is computed from ammonia, $\mathrm{pH}$, and temperature. Total nitrogen can be computed as the sum of nitrite plus nitrate and total ammonia plus organic nitrogen, assuming all nitrite and nitrate is dissolved. Total nitrogen and total phosphorus are used in many methods for determining the trophic condition and enrichment hazard of a water body. Addition of dissolved phosphorus and orthophosphate phosphorus analyses enable determination of the fraction of phosphorus that is biologically available.

Much of the historical trace-metal data available at the study sites is for total recoverable concentration, which is determined from an unfiltered sample. Prior to 1988, most trace-metal standards in Colorado were based on total recoverable concentrations. In 1988, many of these standards were changed and now are based on dissolved concentrations and a relation with hardness. Therefore, future analyses for most trace metals in the study area need to be made on filtered samples. The trace metals listed in table 18 are regulated by Colorado water-quality standards and generally were detected in more than 50 percent of samples in the historical data. Cadmium, mercury, and silver concentrations were less than detection limits in at least 50 percent of the samples at all sites. These are not included in the list, but could be considered for analyses on a limited basis at selected sites.

The nonmetallic trace elements boron and selenium are of interest because of irrigation in the study area. Boron affects the suitability of water for irrigation; therefore, analysis for boron would be useful for samples from all sites in the District's water delivery system and service area (sites 3 through 9). Selenium is a constituent in irrigation return flows, which have their greatest effect on surface water quality in the study area at site 9 (South Platte River near Weldona). Several other trace constituents occurred only rarely or in low concentrations in the historical data set and, therefore, were not included in the schedule. These constituents included arsenic, cyanide, mercury, and total sulfide.

Organic pesticides have not been analyzed in any historical samples collected from the study sites. Potentially, the primary source of pesticides in water in the study area is irrigation return flows. Some information about pesticide concentrations at site 9 (South Platte River near Weldona) is needed, but analyses are not necessary for all samples. Triazine herbicides commonly are applied to the soil before planting. Although no standards exist for these herbicides, they have been identified in receiving water downstream from other irrigated areas in the Platte River basin (D.D. Snow and R.F. Spalding, Nebraska Conservation and Survey, written commun., 1988). Triazine analyses would be most useful for samples collected at site 9 in late spring, following the time of maximum application, and in late summer, during the time of maximum irrigation return flow. Analyses for other pesticides may be desirable at site 9. Selection of analytical schedules and sampling frequency need to be based on use of pesticides in the upstream irrigated area. 
The indicator bacteria of most interest, and the only bacteria with a State water-quality standard, is fecal coliform bacteria. Continued fecalcoliform analyses are needed for samples from site 7 (Boulder Creek) and site 10 (Colorado River near Radium). Addition of fecal-coliform analyses would be useful for samples from site 9 (South Platte River near Weldona), particularly if sampling is discontinued at site 8 . Fecal-coliform analyses from upstream sites $(2,3,5$, and 6$)$ indicate little contamination and could be discontinued. Fecal-streptococci concentrations, although not regulated by a standard, are useful in determining the source of fecal contamination. Totalcoliform analyses are not as useful as fecal-coliform analyses and could be discontinued at all sites.

Chlorophyll a concentration provides an indication of phytoplankton biomass. It is more useful than phytoplankton cell counts because it is independent of cell size and, therefore, is less variable as algal populations change. It is more useful than algal-growth potential because it measures actual algal production at the site rather than potential algal production in the laboratory. Also, it commonly is used as an indicator of trophic status. On this basis, addition of chlorophyll a analyses would be informative for all reservoir sites $(1,5$, and 6$)$. Phytoplankton cell counts and algal-growthpotential measurements then would be unnecessary and could be discontinued.

\section{SUMMARY AND CONCLUSIONS}

Data from U.S. Geological Survey water-quality sampling stations at 10 sites in north-central Colorado were analyzed by using a variety of statistical procedures to determine characteristics of the historical data and to evaluate the sampling programs. All these sites were associated with the Colorado-Big Thompson (CBT) Project, which is operated by the Northern Colorado Water Conservancy District and the U.S. Bureau of Reclamation.

\section{Water-quality Data}

Values of specific conductance and $\mathrm{pH}$ were small at all headwater sites and increased downstream. Mean values of specific conductance increased from less than $60 \mu \mathrm{S} / \mathrm{cm}$ at sites 1 through 3 (Lake Granby, Granby Pump Canal, and Adams Tunnel) to about $1,600 \mu \mathrm{S} / \mathrm{cm}$ at site 9 (South Platte River near Weldona). Mean values of $\mathrm{pH}$ increased from about $7.1-7.5$ at sites $1-3$ to about 8.1 at sites 8-10 (South Platte River at Masters, South Platte River near Weldona, and Colorado River near Radium). Nutrient concentrations were low at all sites, with the exception of phosphorus concentrations at downstream sites in the South Platte River basin. Based on total phosphorus concentrations, the risk of eutrophication-related water-quality problems is small to moderate at reservoir sites. Most trace constituent concentrations were low, but copper and lead concentrations occasionally exceeded State water-quality standards at several sites (1, Lake Granby; 2, Granby Pump Canal; 3, Adams Tunnel; 5, Horsetooth Reservoir; and 10, Colorado River near Radium). Bacterial concentrations were very low at all sites except those downstream from municipal wastewater-treatment plants (site 7, Boulder Creek, and site 8, South Platte River at Masters). 
Trend analyses indicated that specific conductance, dissolved-solids concentration, and the concentrations of major dissolved constituents have decreased at many sites. The magnitude of significant decreases in dissolvedsolids concentration ranged from about $0.3 \mathrm{mg} / \mathrm{L}$ per year at site 4 (0lympus Tunnel) to about $27 \mathrm{mg} / \mathrm{L}$ per year at site 9 (South Platte River near Weldona). The only significant increasing trends for any of these properties or constituents occurred at site 10 (Colorado River near Radium), where dissolved-solids concentration increased $4.4 \mathrm{mg} / \mathrm{L}$ per year. This site is downstream from CBT diversions out of the Colorado River basin and may be affected by these diversions. Other general trends indicated that phosphorus concentrations have decreased about 87-94 percent at the reservoir sites (1, 5, and 6) and that concentrations of fecal coliform bacteria have decreased about 80-96 percent downstream from treatment plants (sites 7 and 8).

\section{Sampling Programs}

Data from selected pairs of sites were compared by using regression analysis to test for similarities between the sites. Site 3 (Adams Tunne1) was compared to site 4 (0lympus Tunnel), and site 8 (South Platte River at Masters) was compared to site 9 (South Platte River near Weldona). Neither comparison indicated substantial differences between sites. As long as sampling is continued at one site in each pair, most data from the other site are redundant. Subsequent analyses of sampling frequency were applied only to the site with the longer period of record in each pair (sites 3 and 9).

Analysis of sampling frequency at streamflow sites was based on nonparametric testing for significant differences in characteristics of the distributions of data subsets, visual inspection of plots of these distributions, and comparison of trend analysis results from the entire data set and selected subsets. Data subsets were selected to represent decreased sampling frequencies at bimonthly or quarterly intervals. No substantial loss of information was identified for decreasing sampling frequency to bimonthly at sites 2, 3 , 7, and 10 (Granby Pump Canal, Adams Tunnel, Boulder Creek, and Colorado River near Radium) or quarterly at site 9 (South Platte River near Weldona). The same procedures were applied to test for differences among sampling locations and between sampling depths at two reservoir sites. Based on results of these tests, sampling at two locations (north and south stations) and two depths (surface and bottom) is necessary to define the variability of certain constituents at site 5 (Horsetooth Reservoir). At site 6, sampling at one location and two depths is adequate.

A schedule of onsite measurements and laboratory analyses was developed based on criteria of providing consistency and determining compliance with water-quality standards. Use of the analytical schedule at all sites would provide a uniform data set for the study area. Comparisons among sites would be more meaningful and common trends more easily defined.

The analyses used in this study were based on existing data and State water-quality standards. The actual selection of a sampling program for an individual site could be based on factors not considered in this report. 


\section{REFERENCES CITED}

Chambers, J.M., Cleveland, W.S., Kleiner, Beat, and Tukey, P.A., 1983, Graphical methods for data analysis: Boston, Duxbury Press, 395 p.

Colorado Department of Health, 1986, Classification and numeric standards-upper Colorado River basin and North Platte River basin (planning region 12)--3.3.0: Denver, Water Quality Control Commission, 48 p. 1987, Classification and numeric standards--South Platte River basin, Laramie River basin, Republican River basin, and Smoky Hill River basin-3.8.0: Denver, Water Quality Control Commission, 108 p.

Conover, W.J., 1980, Practical nonparametric statistics (2d ed.): New York, John Wiley, $493 \mathrm{p}$.

Conover, W.J., and Iman, R.I., 1981, Rank transformation as a bridge between parametric and nonparametric statistics: The American Statistician, v. 35, no. 3, p. 124-139.

Gilliom, R.J., and Helsel, D.R., 1986, Estimation of distributional parameters for censored trace level water quality data--1. Estimation techniques: Water Resources Research, v. 22, no. 2, p. 135-146.

Helsel, D.R., and Cohn, T.A., 1988, Estimation of descriptive statistics for multiply censored water quality data: Water Resources Research, v. 24, no. 12 , p. 1997-2004.

Hirsch, R.M., Slack, J.R., and Smith, R.A., 1982, Techniques of trend analysis for monthly water quality data: Water Resources Research, v. 18, no. 1 , p. 107-121.

Hirsch, R.M., and Slack, J.R., 1984, A nonparametric trend test for seasonal data with serial dependence: Water Resources Research, v. 20, no. 6, p. 727-732.

Minges, D.R., 1983, Selected hydrologic characteristics of the South Platte River in the vicinity of the proposed Narrows Reservoir near Fort Morgan, Colorado: U.S. Geological Survey Water-Resources Investigations Report $82-4071,25 \mathrm{p}$.

Northern Colorado Water Conservancy District, 1987, Waternews, v. 5, no. 2: Loveland, Colorado, Northern Colorado Water Conservancy District, 28 p.

SAS Institute Inc., 1985a, SAS user's guide: basics--version 5 edition: Cary, N.C., SAS Institute Inc., 1290 p.

1985b, SAS user's guide: statistics--version 5 edition: Cary, N.C., SAS Institute Inc., $956 \mathrm{p}$.

Tanji, K.K., and Biggar, J.W., 1972, Specific conductance model for natural waters and soil solutions of limited salinity levels: Water Resources Research, v. 8, no. 1, p. 145-153.

U.S. Bureau of Reclamation (Water and Power Resources Service), 1981, Project data: Denver, U.S. Bureau of Reclamation, $1463 \mathrm{p}$.

U.S. Bureau of Reclamation (Water and Power Resources Service), 1985, 1984 Summary statistics, Vol. 1 Water, land, and related data: Denver, U.S. Bureau of Reclamation, $315 \mathrm{p}$.

U.S. Environmental Protection Agency, 1986, Quality criteria for water 1986: EPA 440/5-86-001 (updated November 1986 and May 1987).

U.S. Geological Survey, 1986, Water resources data for Colorado, Water year 1985, Volume 1. Missouri River basin, Arkansas River basin, and Rio Grande basin: U.S. Geological Survey Water-Data Report C0-85-1, 353 p. 1988a, Water resources data for Colorado, Water year 1987, Volume 1. Missouri River basin, Arkansas River basin, and Rio Grande basin: U.S. Geological Survey Water-Data Report C0-87-1, 409 p. 1988b, Water resources data for Colorado, Water year 1987, Volume 2. Colorado River basin: U.S. Geological Survey Water-Data Report C0-87-2, 394 p. 
HYDROLOGIC DATA 


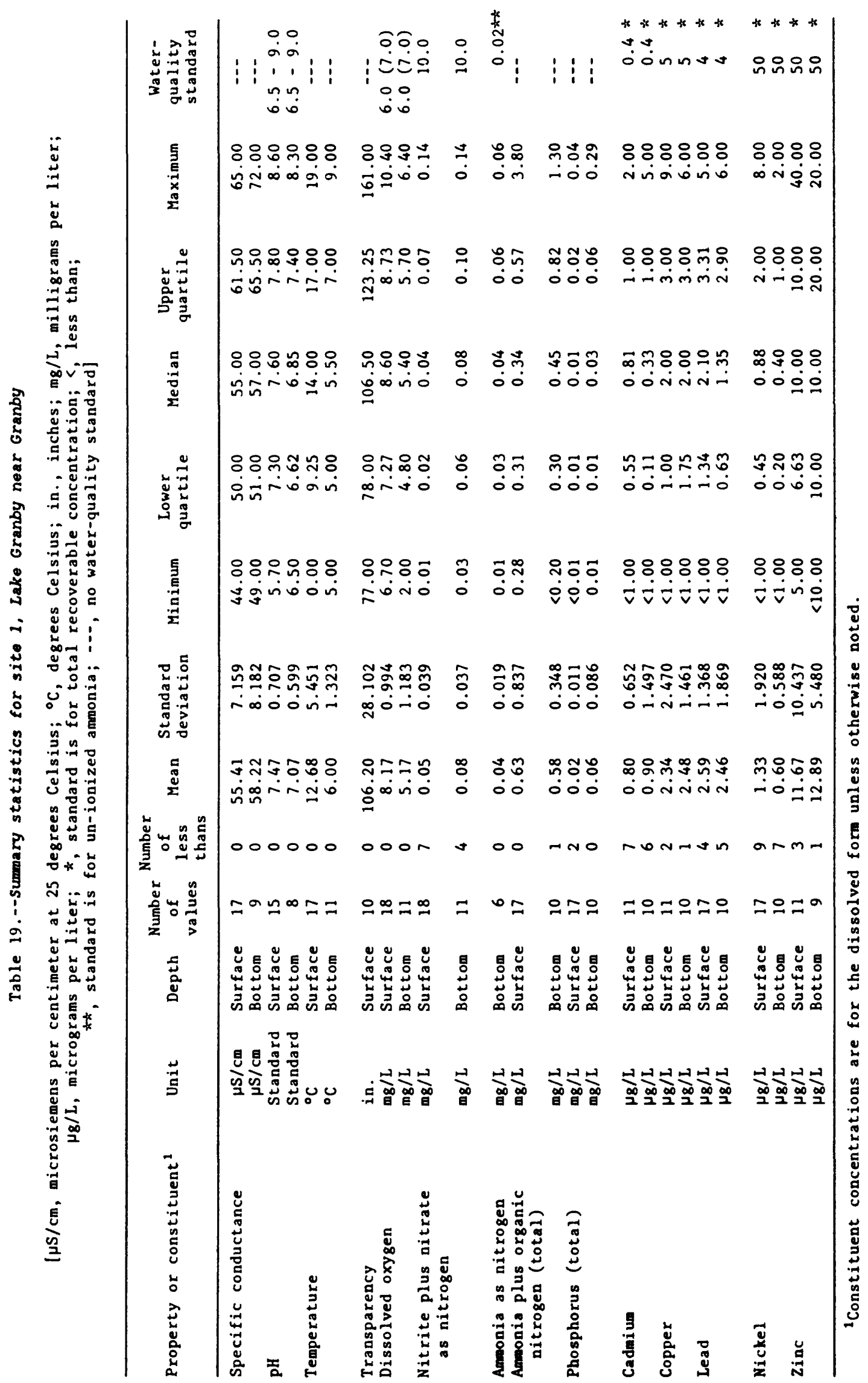




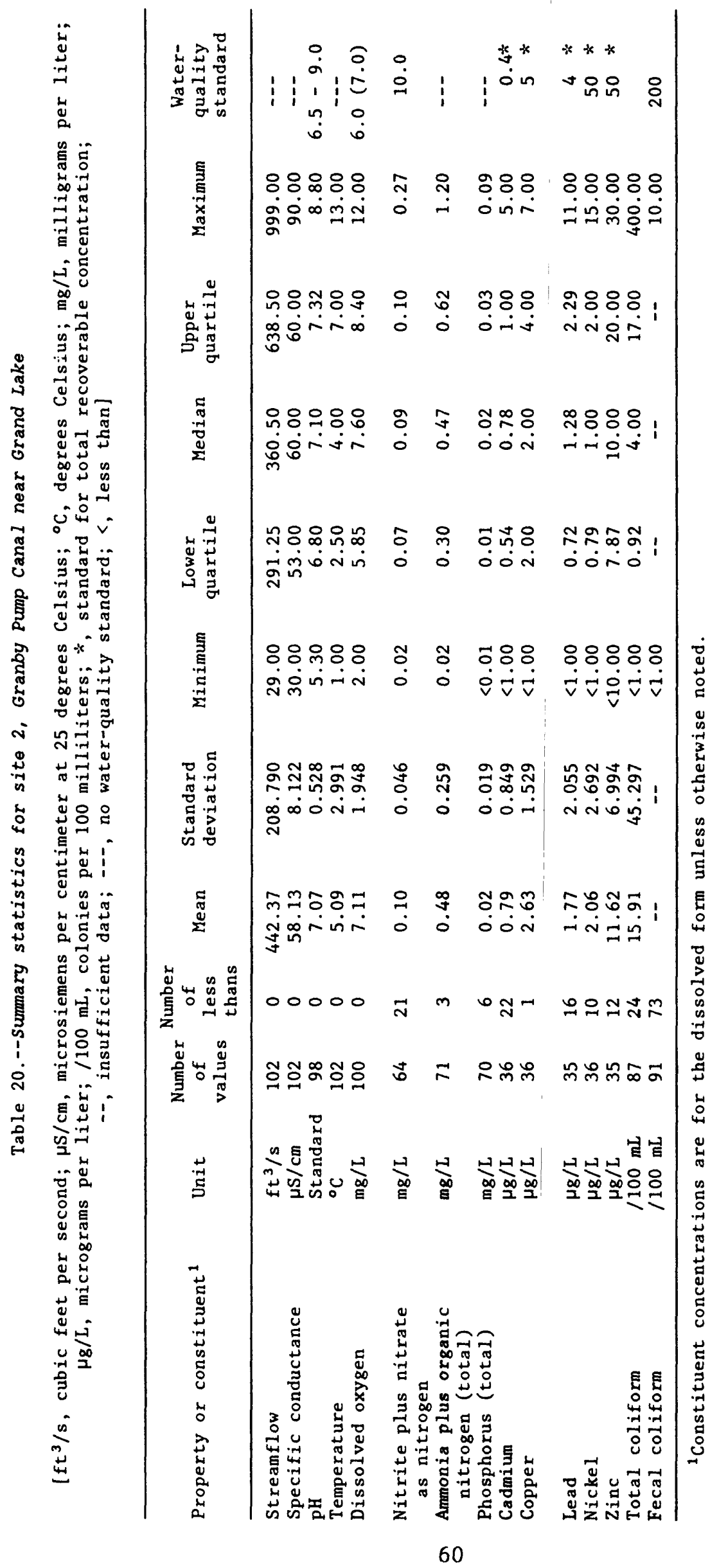




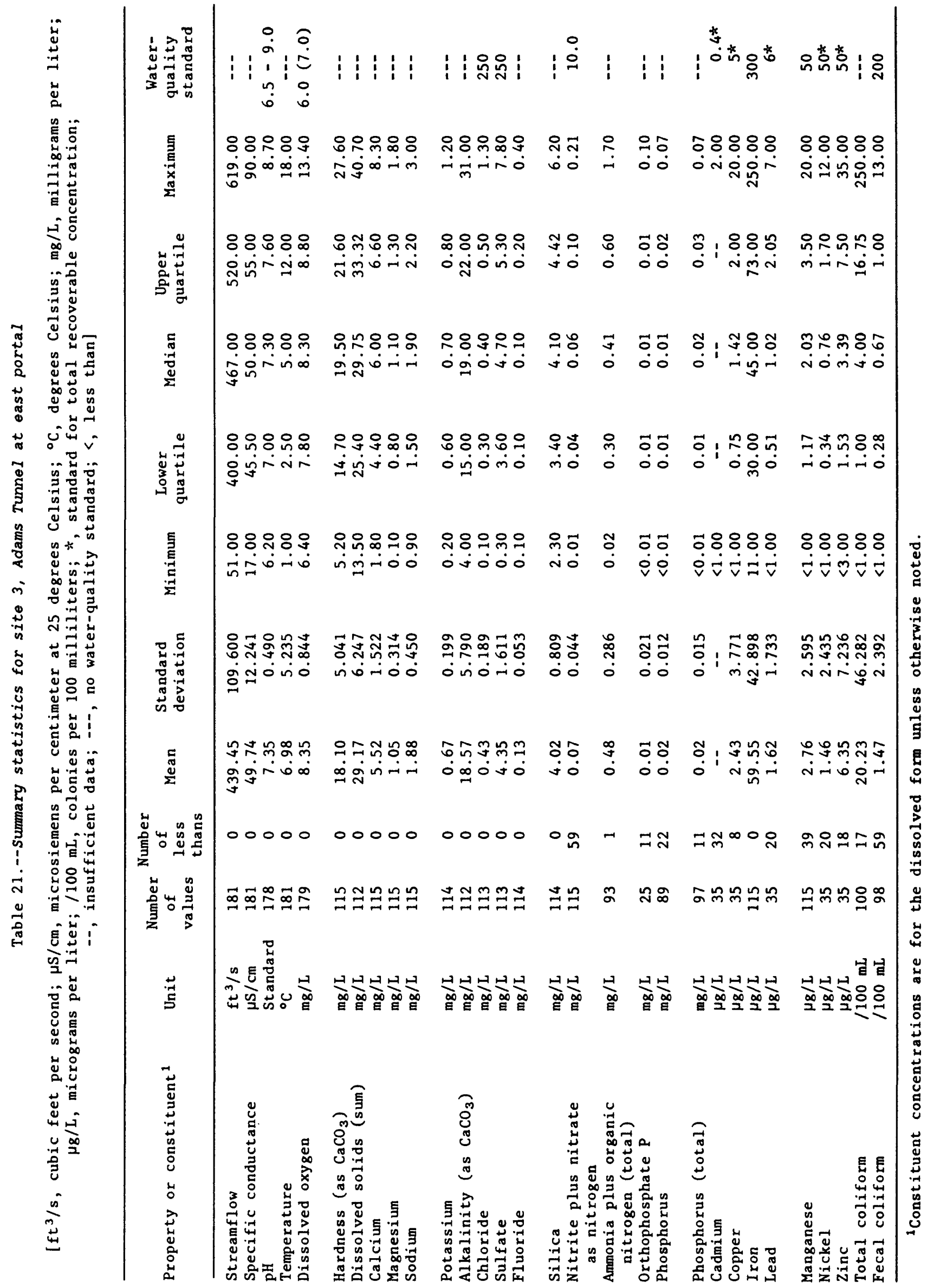




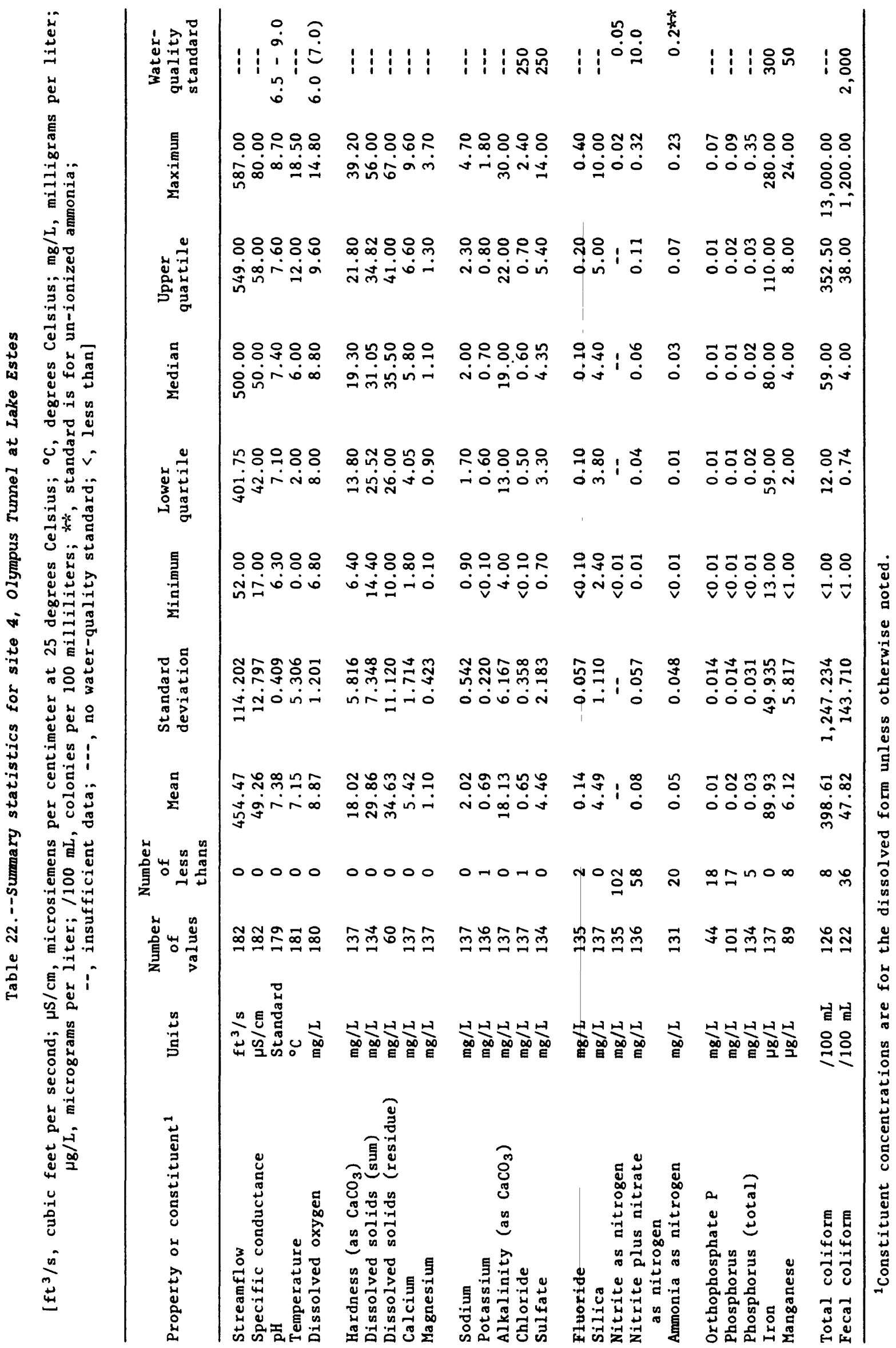




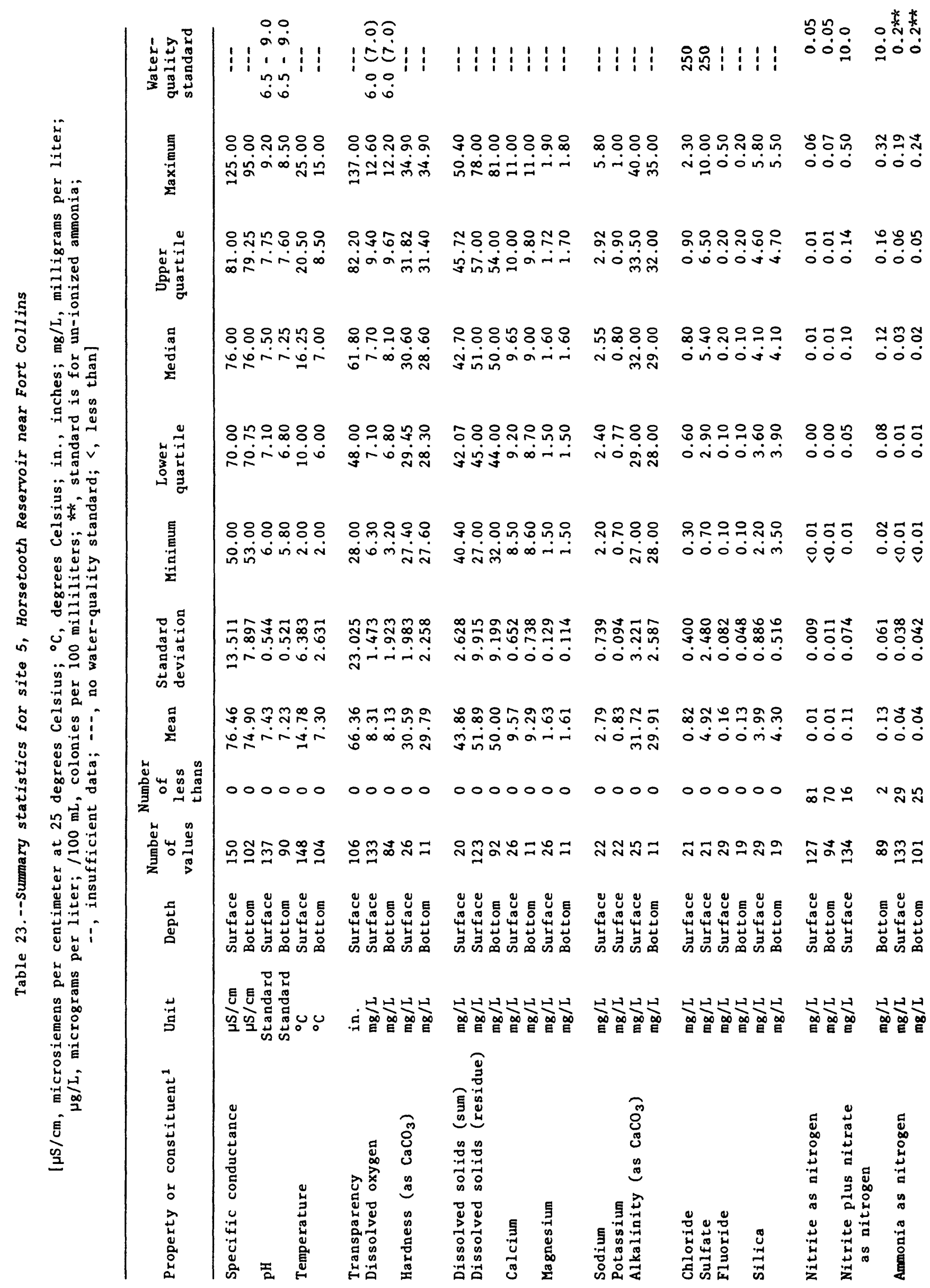




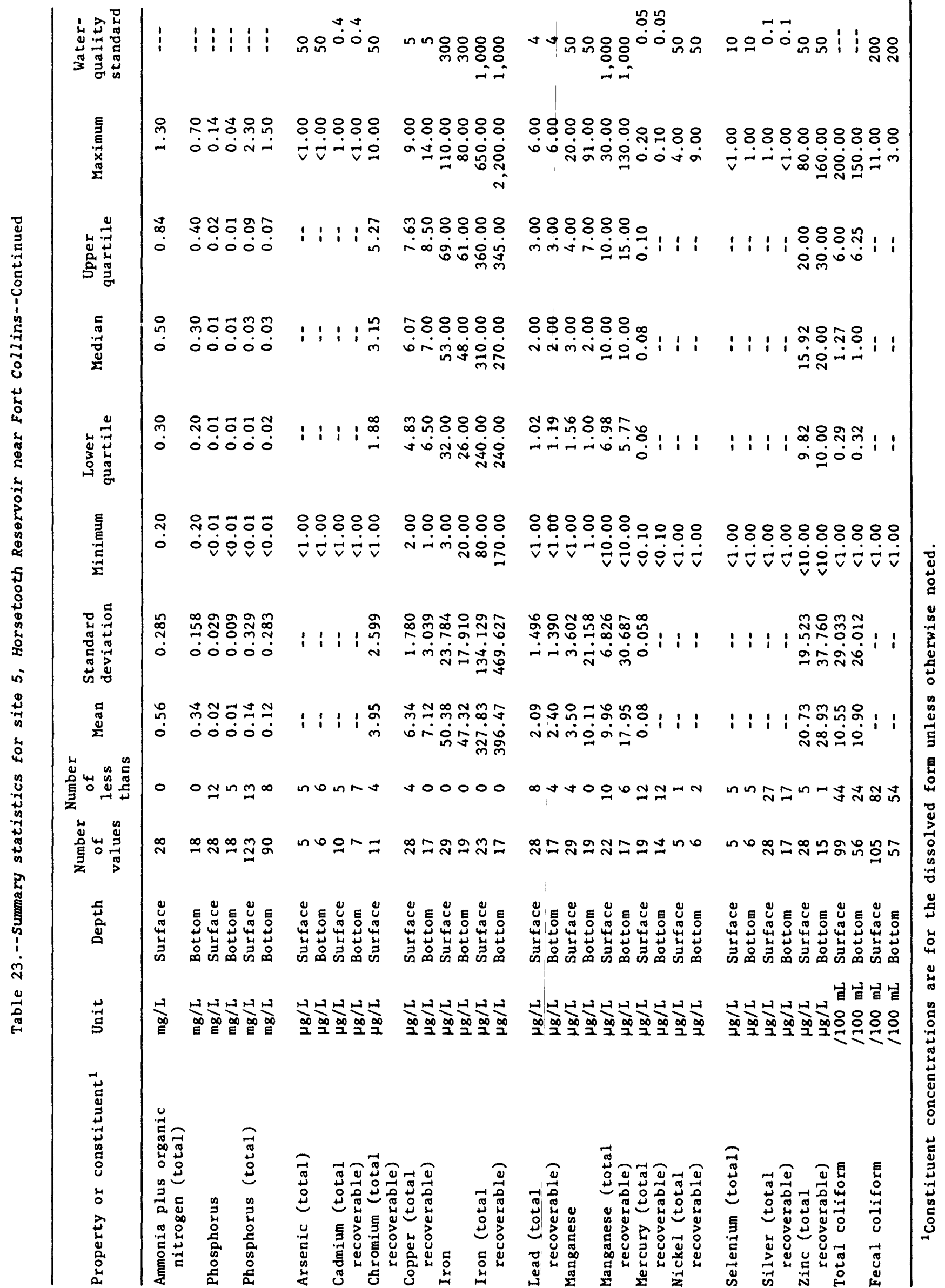




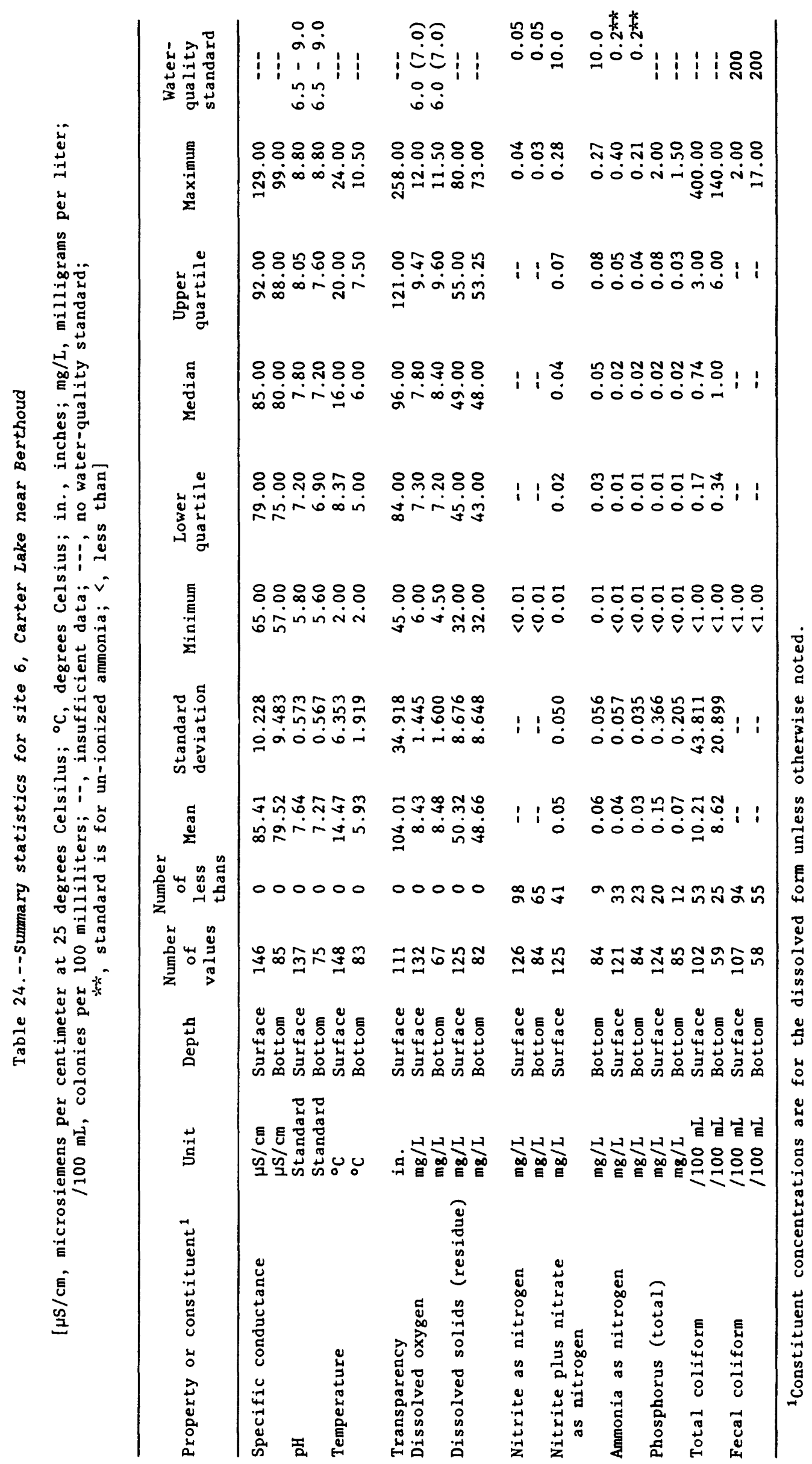




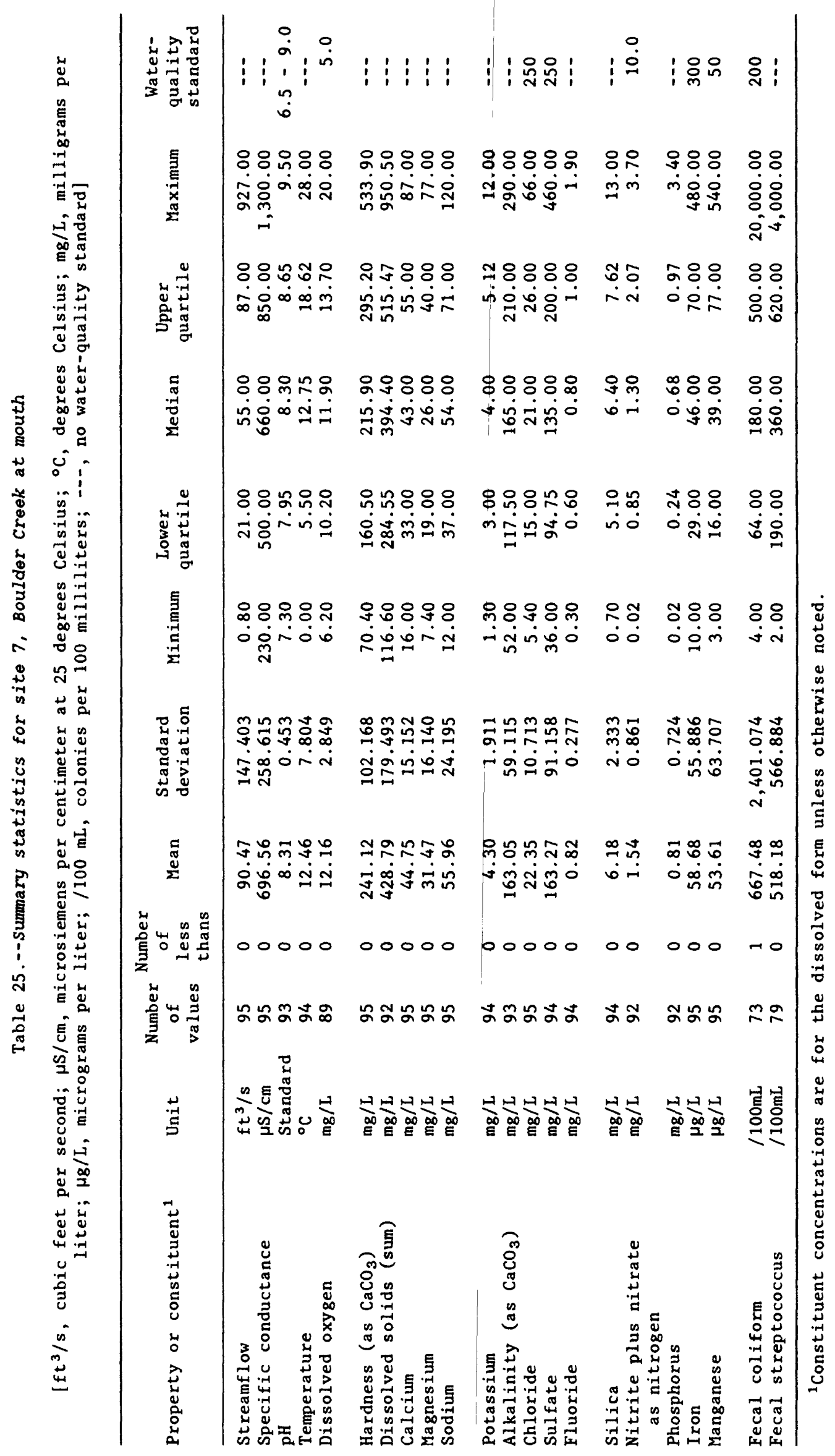




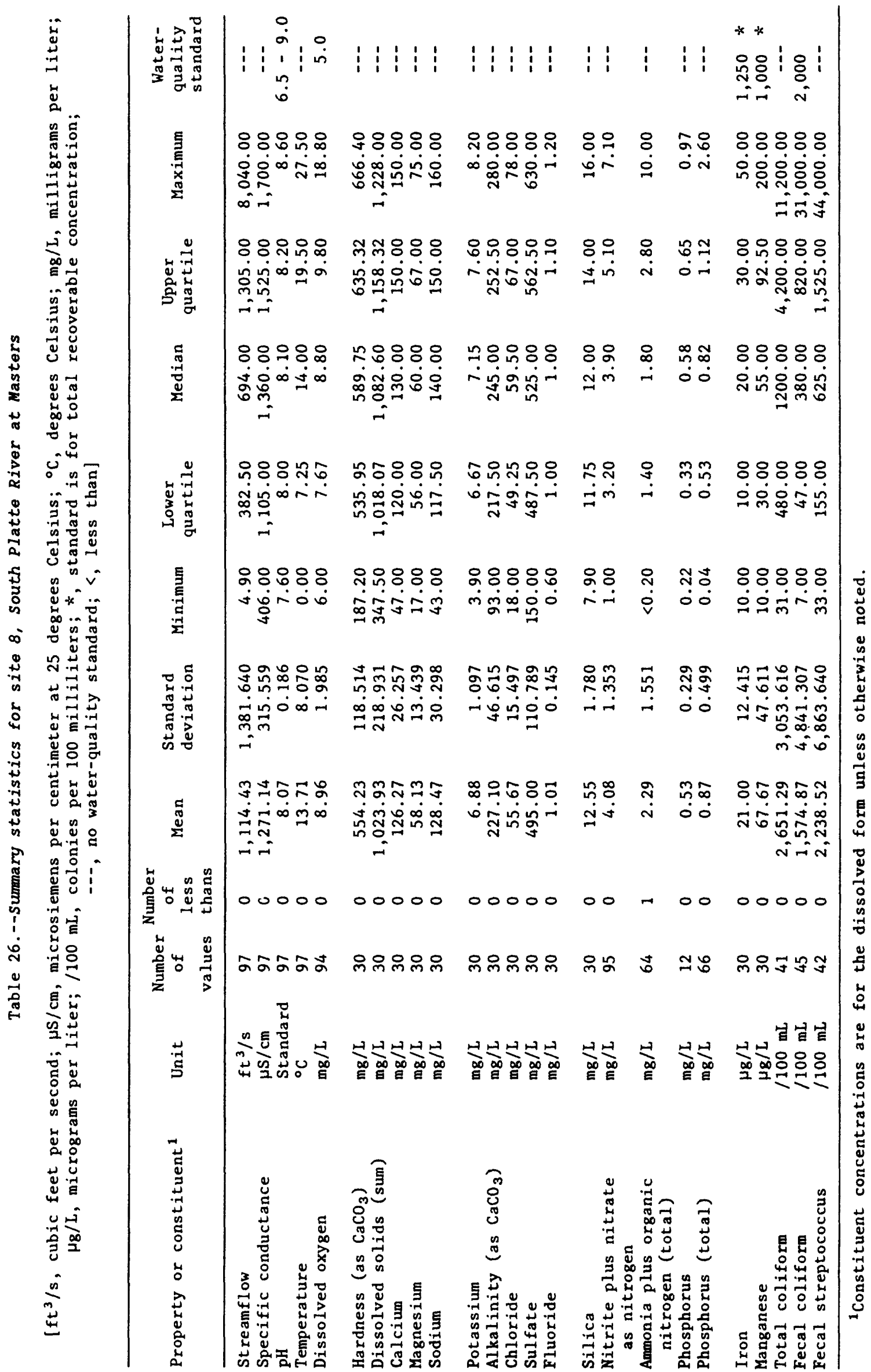




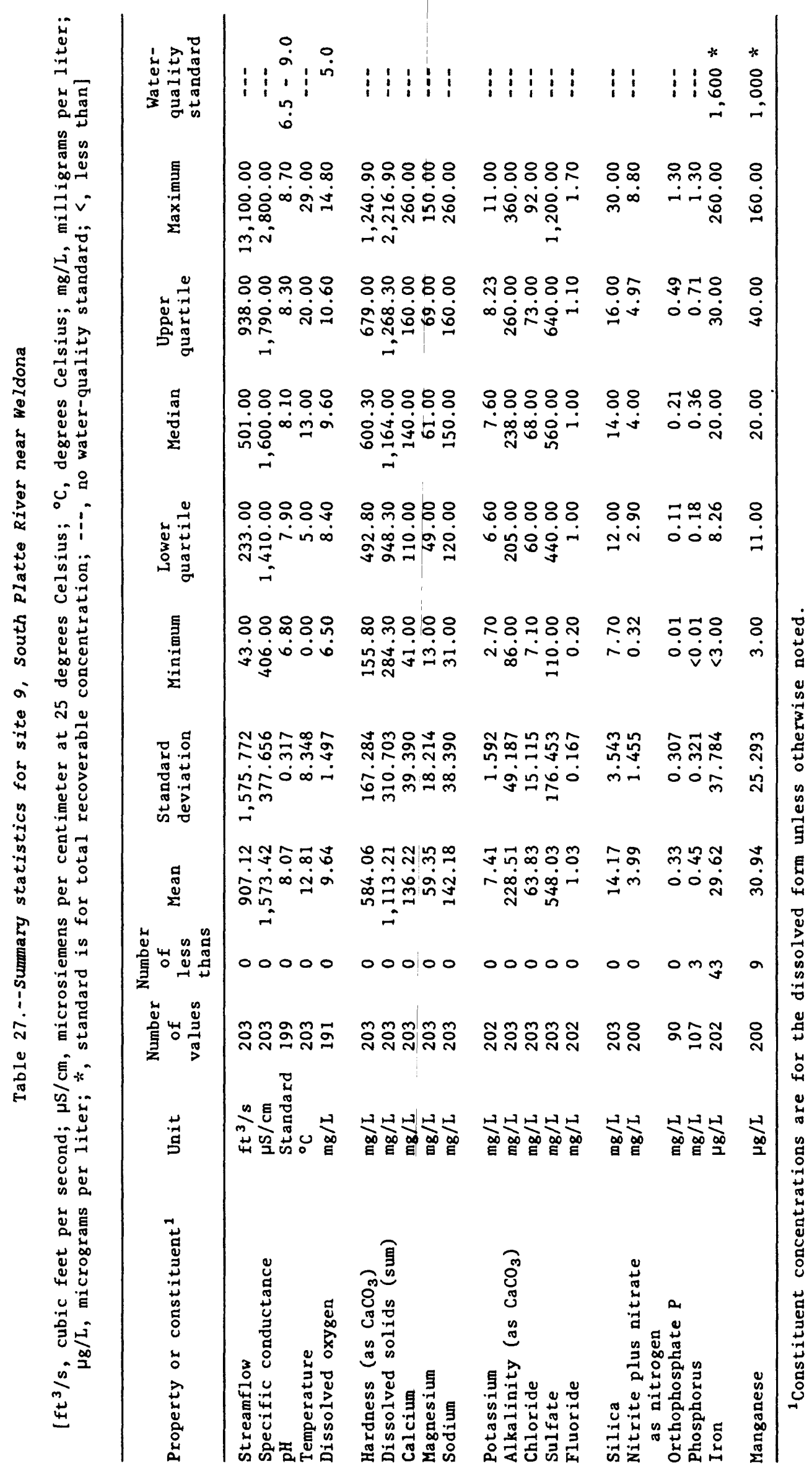




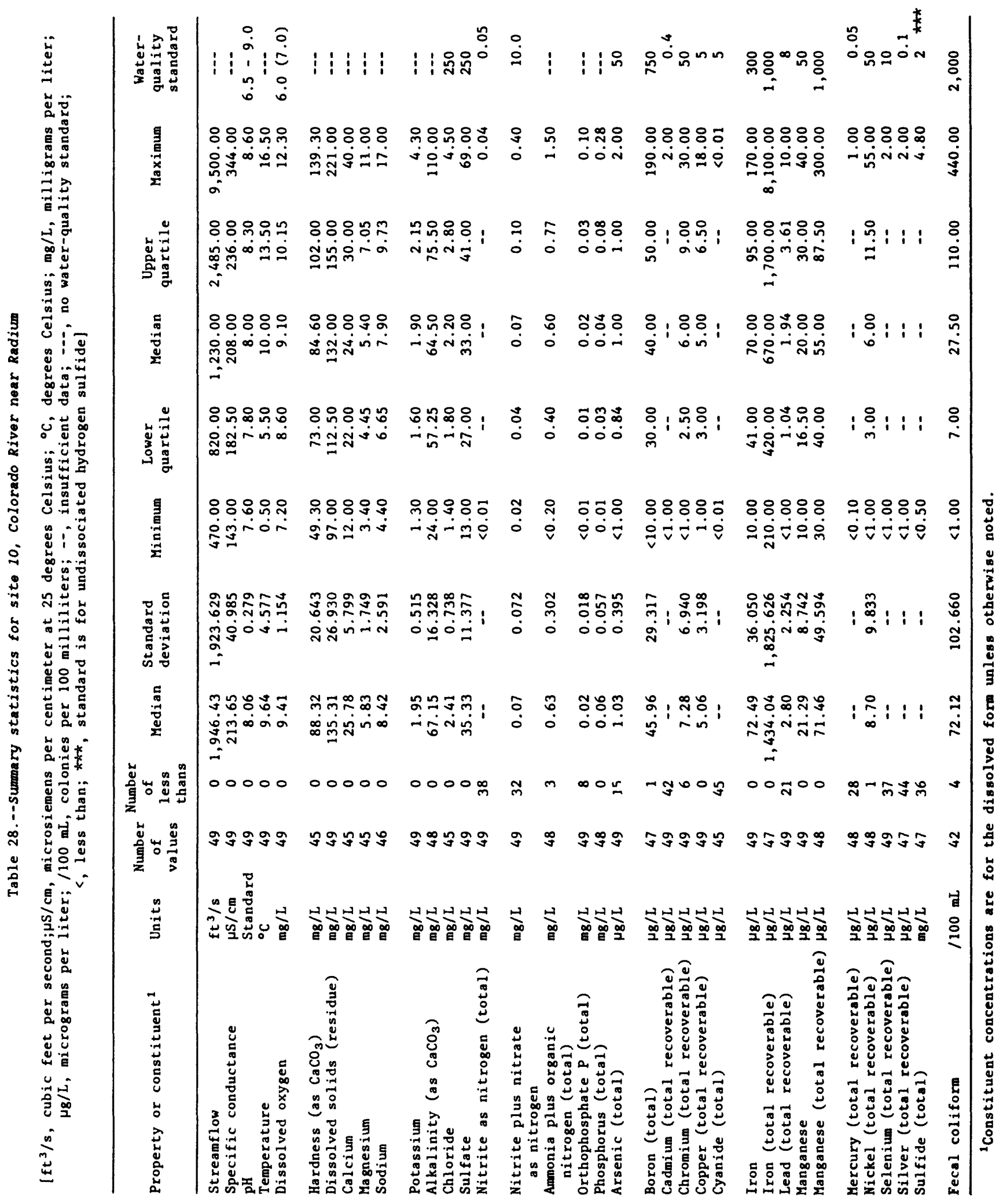




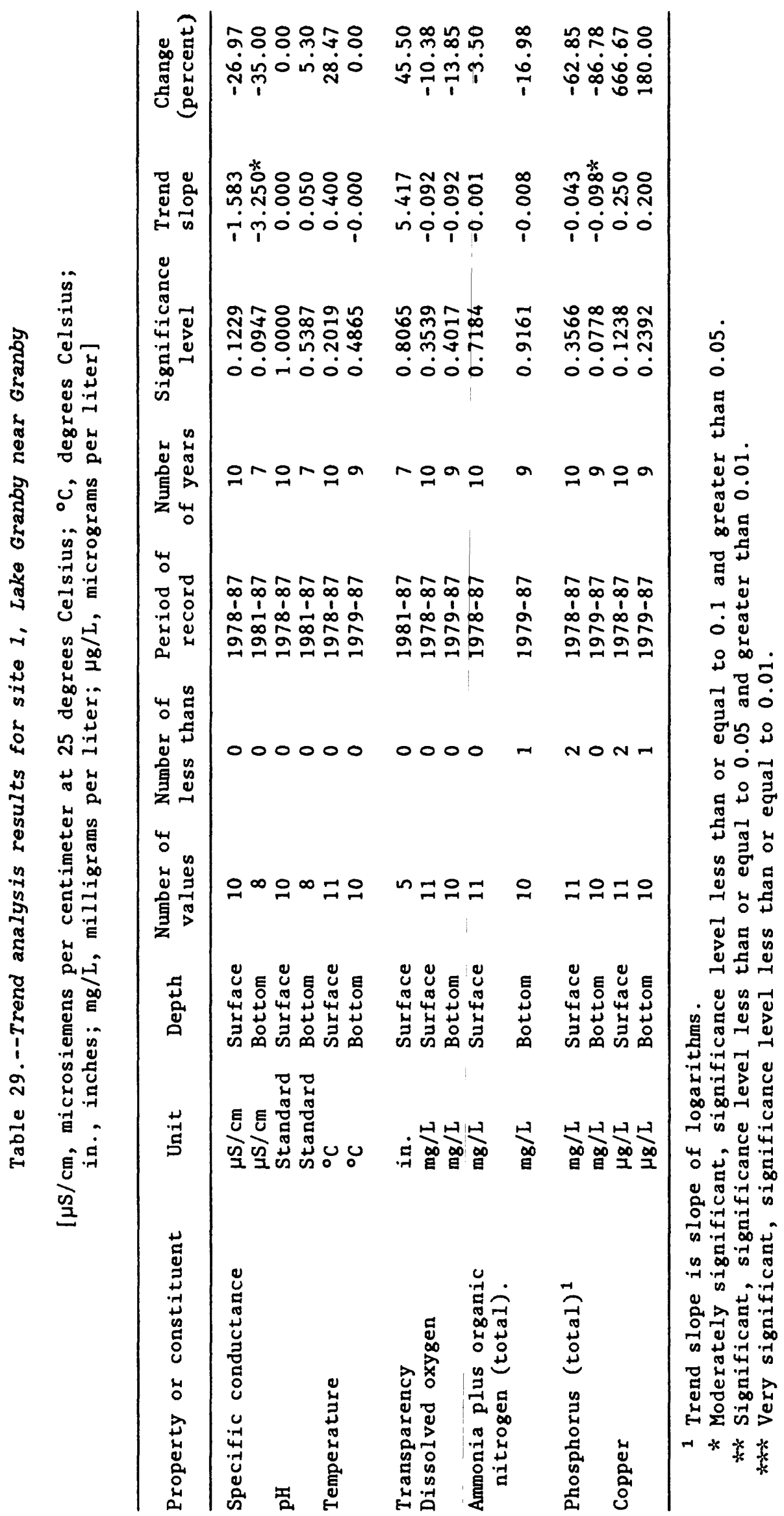




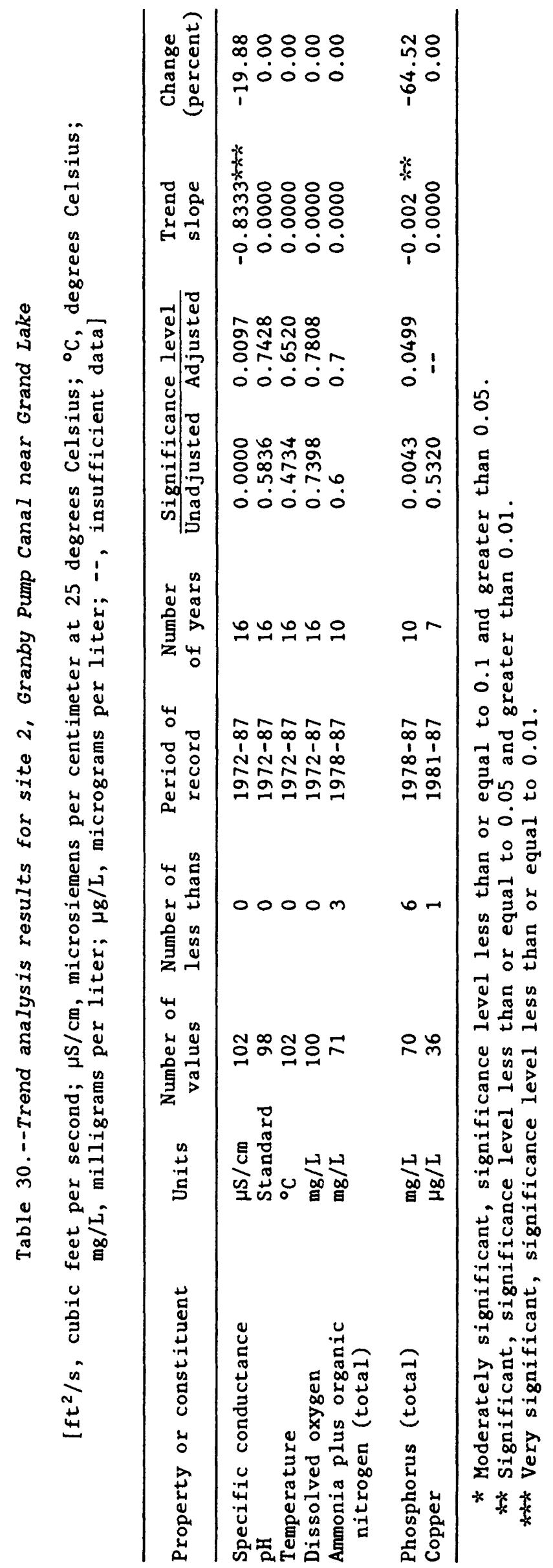




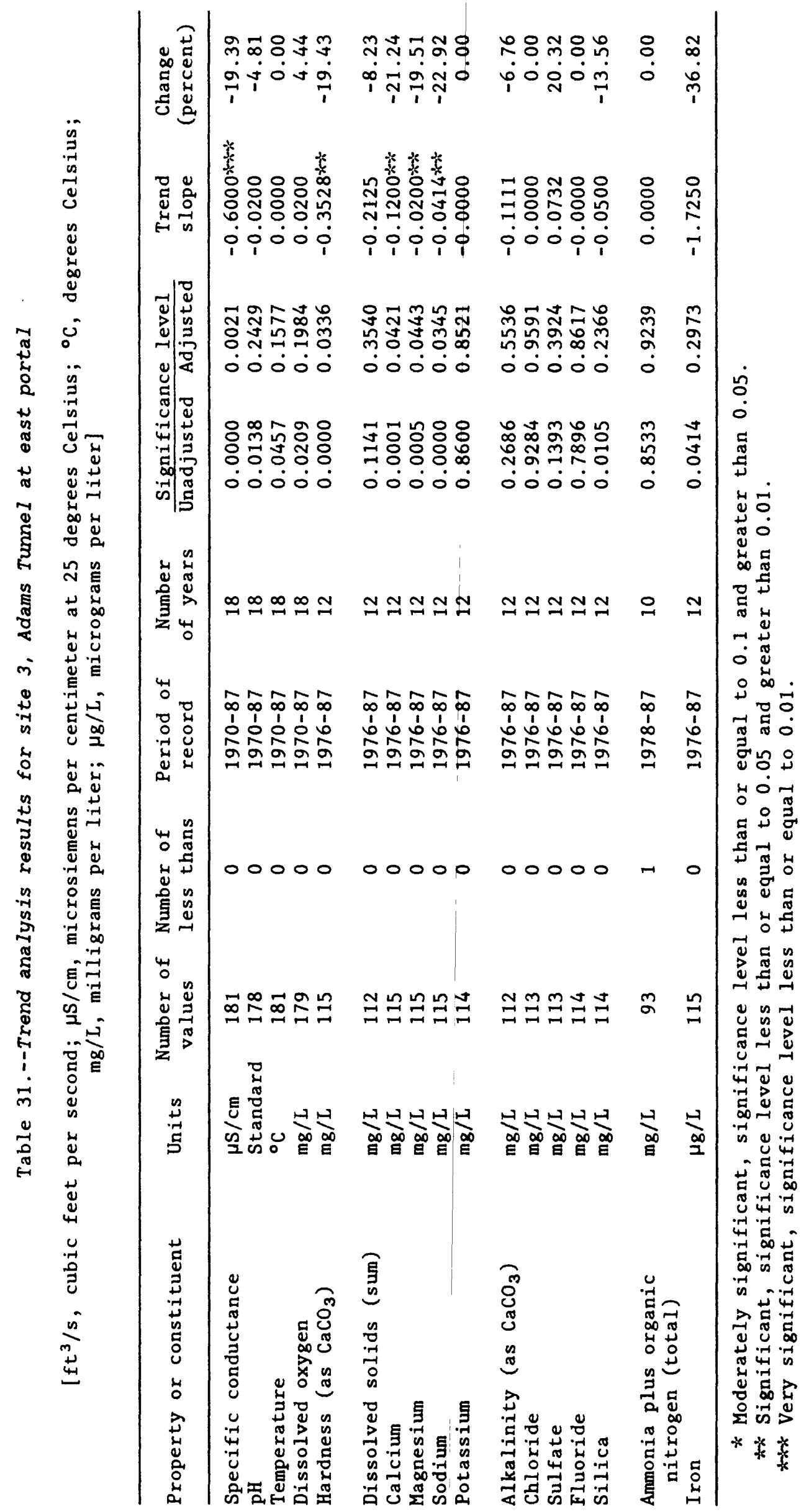




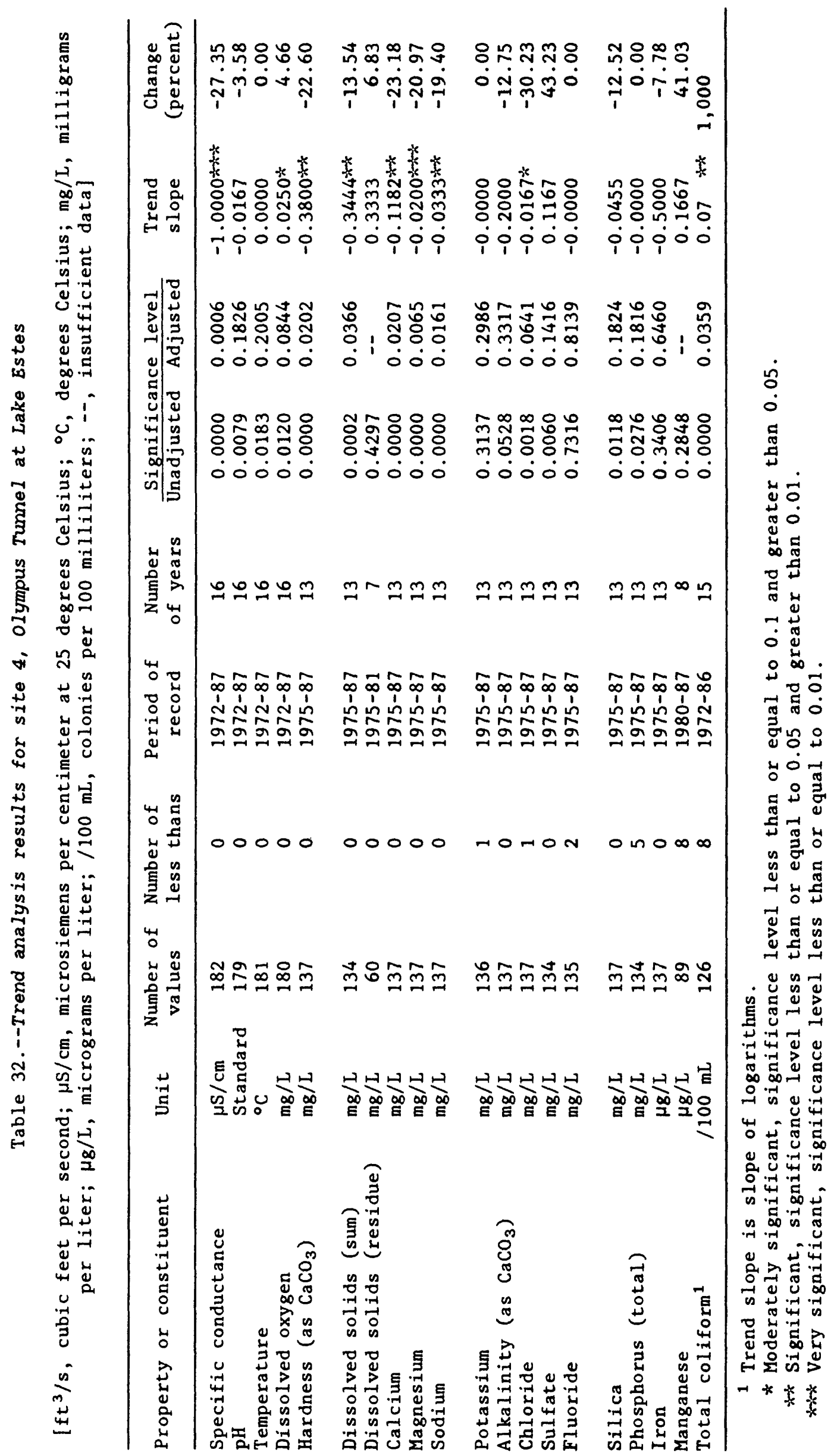




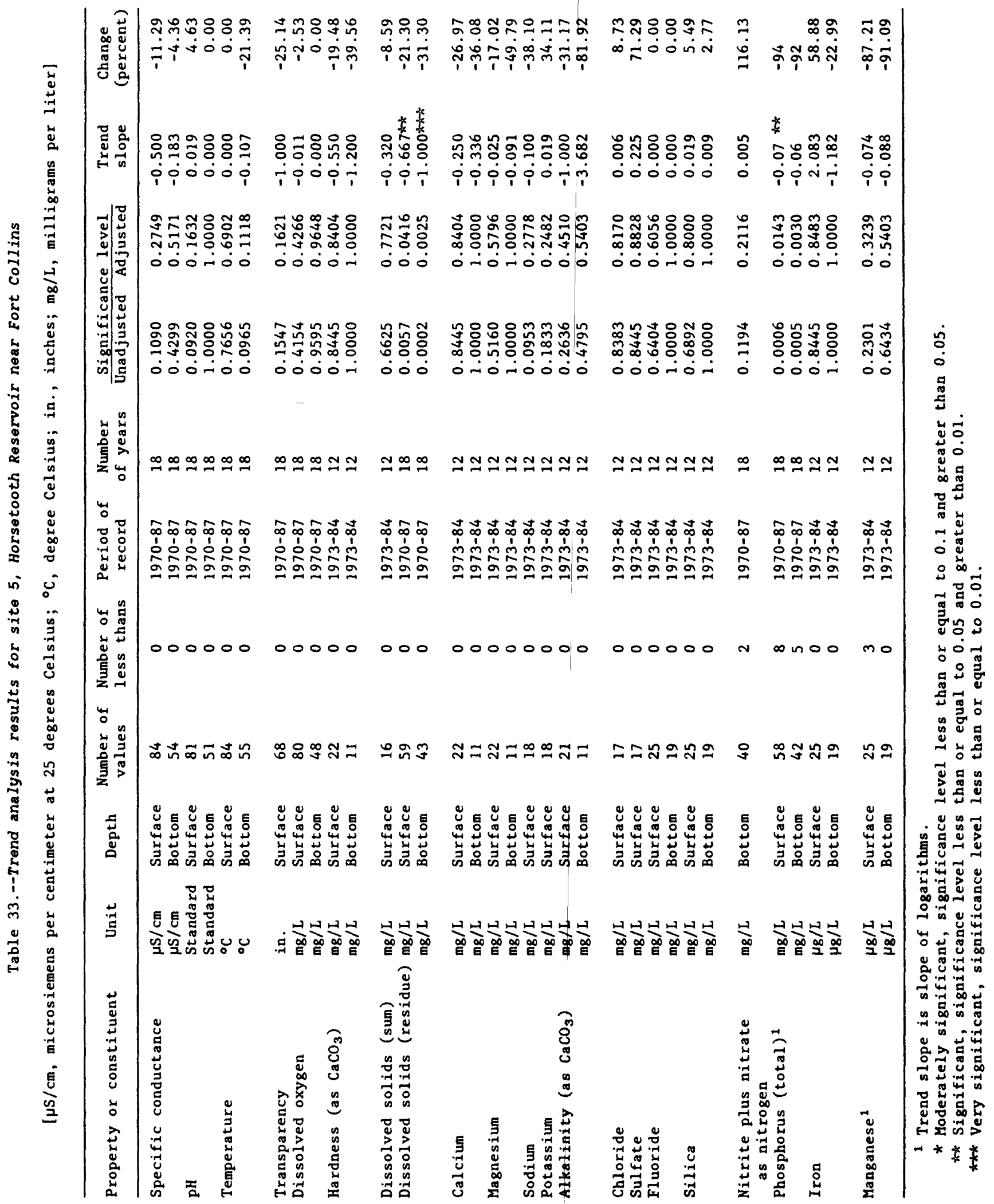




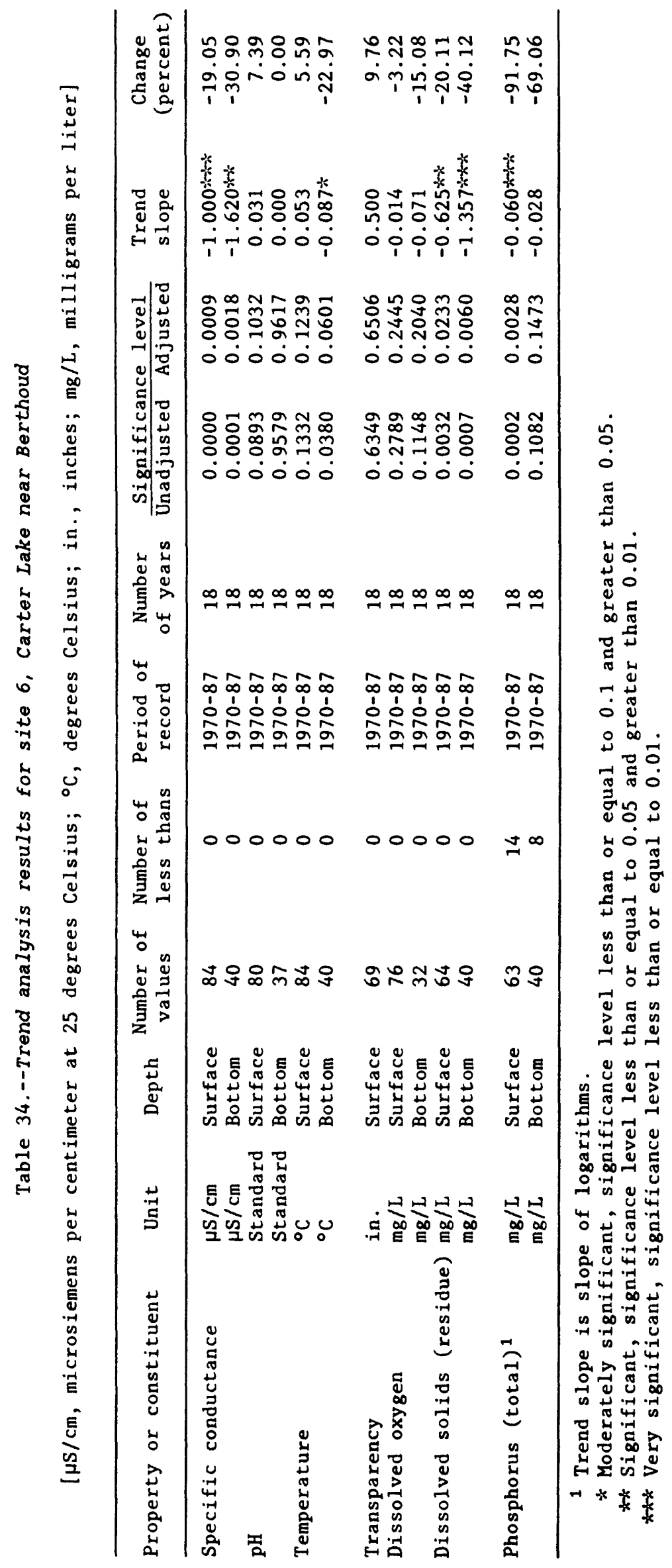




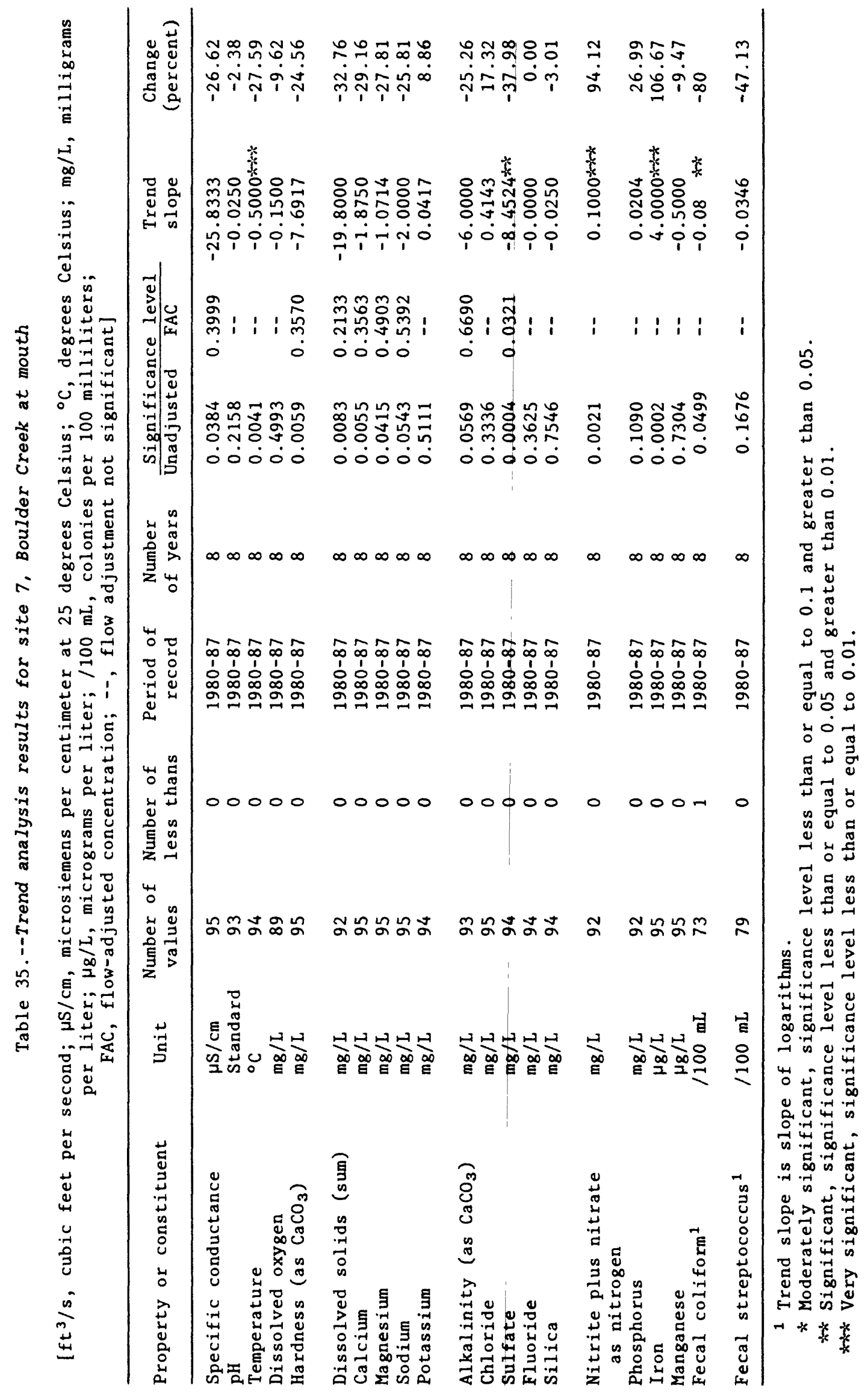




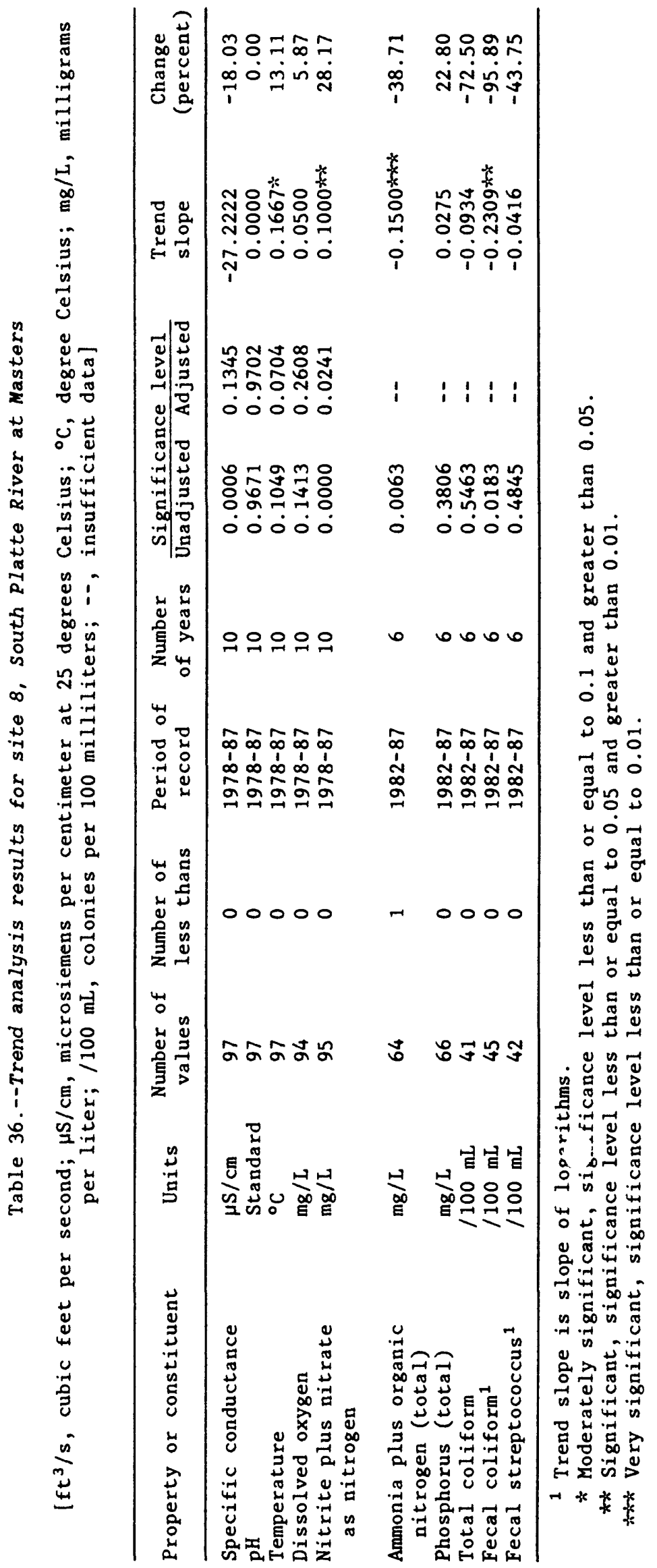




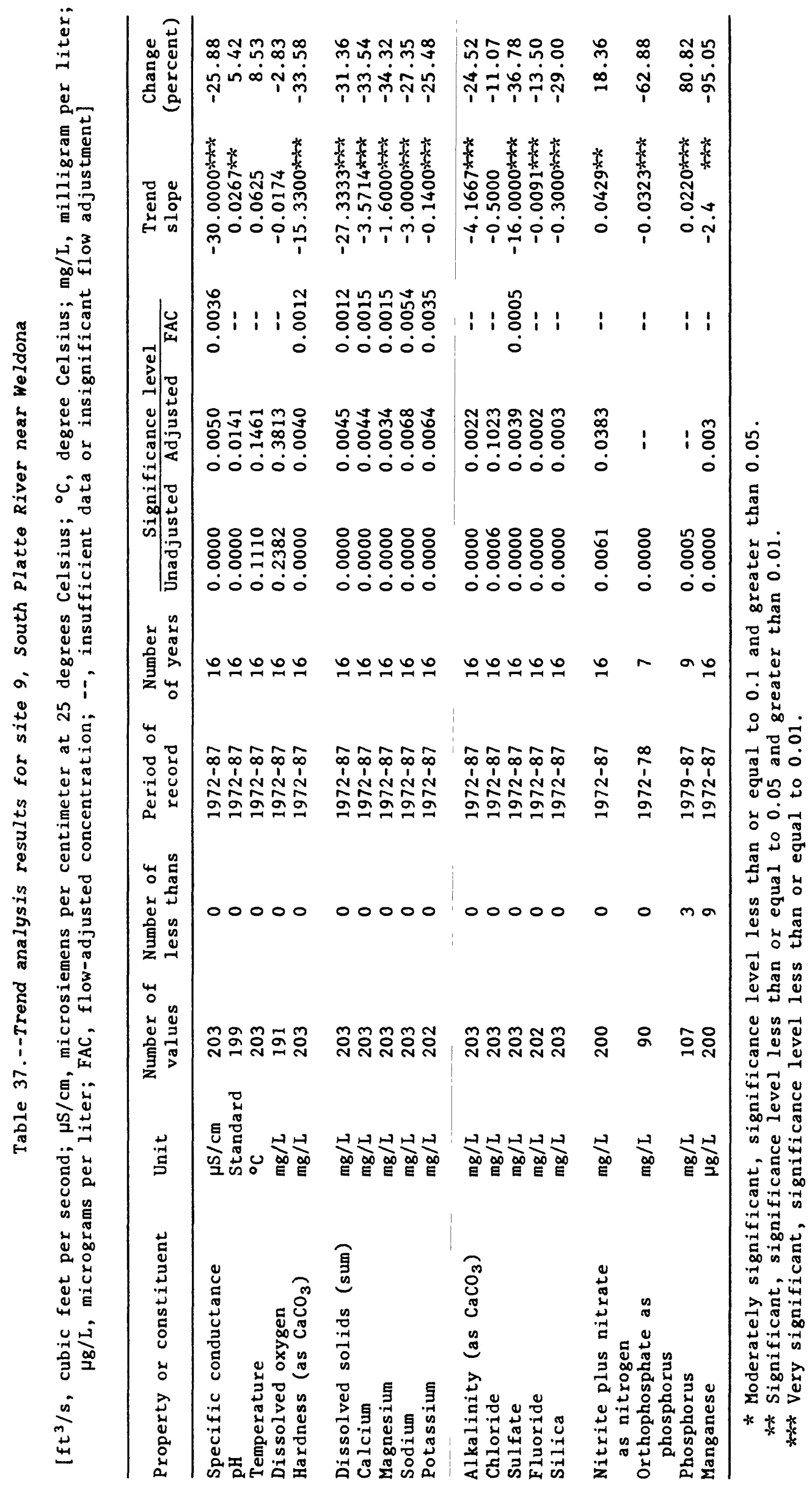




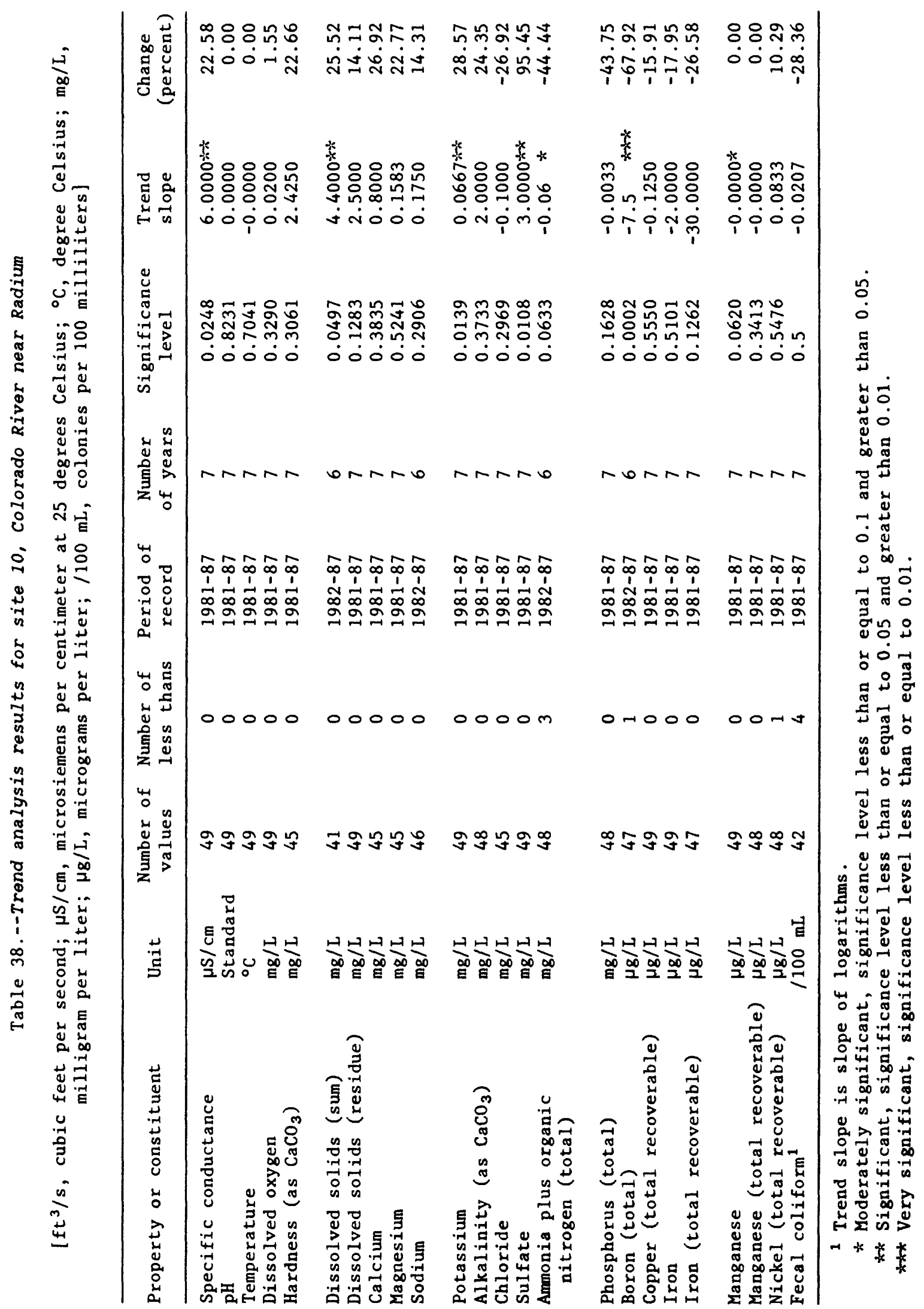

